\title{
42. DIATOM UNITS AND THE PALEOGEOGRAPHY OF THE BLACK SEA IN THE LATE CENOZOIC (DSDP, LEG 42B)
}

Anastasia P. Jousé and Valentina V. Mukhina, Institute of Oceanology, Academy of Sciences of the USSR, Moscow

\section{INTRODUCTION}

A major reason for the studying of the remains of diatom algae in the sediments of the Black Sea is to assist in determining the age and origin of the sediments, and in reconstructing the paleogeographical environments of sedimentation.

Until recently little was known about the deep-sea sediments of the Black Sea. The most valuable data were those relating to the diatoms in the Holocene sediments sampled during the expedition aboard Akademik Vavilov in 1971. These data show that the ecological diatom assemblages have undergone a succession of complicated changes after the Novoeuxian times, the last fresh-water stage of the history of the Black Sea.

The materials from Glomar Challenger have opened a new page in the history of the Black Sea, disclosing some hitherto unknown aspects in the development of the Black Sea diatom flora during the PliocenePleistocene. Diatom remains in these sediments are one of the major organogenic components. There is extensive literature on the diatoms of Neogene age found in numerous sections of the Black Sea coasts, but the lack of comparable data off-shore has made the interpretation of the Glomar Challenger materials quite difficult.

\section{LOCALITIES AND PREPARATION OF SAMPLES}

Geographical positions of the drilling sites of Leg 42B of the Deep Sea Drilling Project and of the Akademik Vavilov core are shown in Table 1 and Figure 1.

TABLE 1

Location of Drilled Sites in the Black Sea

\begin{tabular}{llll}
\hline Hole $379 \mathrm{~A}$ & $43^{\circ} 00.98^{\prime} \mathrm{N}$ & $36^{\circ} 00.68^{\prime} \mathrm{E}$ & water depth $2171 \mathrm{~m}$ \\
Hole 380 & $42^{\circ} 05.98^{\prime} \mathrm{N}$ & $29^{\circ} 36.90^{\prime} \mathrm{E}$ & water depth $2115 \mathrm{~m}$ \\
Hole $380 \mathrm{~A}$ & $42^{\circ} 05.99^{\prime} \mathrm{N}$ & $29^{\circ} 36.82^{\prime} \mathrm{E}$ & water depth $2115 \mathrm{~m}$ \\
Site 381 & $41^{\circ} 40.25^{\prime} \mathrm{N}$ & $29^{\circ} 24.96^{\prime} \mathrm{E}$ & water depth $1750.5 \mathrm{~m}$ \\
Core 1857 & $43^{\circ} 40^{\prime} \mathrm{N}$ & $30^{\circ} 23^{\prime} \mathrm{E}$ & water depth $920 \mathrm{~m}$ \\
\hline
\end{tabular}

The material was treated in accordance with standard procedures used in the Laboratory of Micropaleontology, Department of Ocean Geology, Institute of Oceanology, Academy of Sciences, USSR. The method is as follows: $0.5 \mathrm{~g}$ of sediment is heated in a $10 \% \mathrm{Na}_{5} \mathrm{P}_{3} \mathrm{O}_{10}$ solution, then boiled for 60 minutes in a $30 \% \mathrm{H}_{2} \mathrm{O}_{2}$ solution. During the next 5 to 6 days, samples are washed in distilled water to remove tripolyphosphate and particles of pelite. Finally, the sample is washed and a portion of the material is mounted under a cover glass and examined under the microscope. This procedure allows calculation of the number of diatom valves per gram of sediment. The absolute abundance of diatoms is thus somewhat understated.

Figures 2 through 6 list the most characteristic diatom species from Holes 379A, 380, 380A, Site 380, and Core 1857, with their relative abundance in each examined sample.

Plates 1-23 show the photomicrographs of the most typical diatom species of the Pliocene-PleistoceneHolocene of the Black Sea.

\section{Hole 379A}

A total of 190 samples from 63 cores were examined; they include Samples 68, CC to Core 31, Samples 29-6, 2-4 cm, 29-5, 146-147 cm, 28-6, $121-123 \mathrm{~cm}, 26-4,74-76$ $\mathrm{cm}, 25-5,95-106 \mathrm{~cm}, 23$, CC to $22-4,72-74 \mathrm{~cm}, 19-6,56-$ $58 \mathrm{~cm}, 19-2,70-90 \mathrm{~cm}, 15-4,52-70 \mathrm{~cm}, 15-4,48-50 \mathrm{~cm}$, and $14, \mathrm{CC}$ to $13-3,70-72 \mathrm{~cm}$. Above Core 13 the sediments were barren of diatom remains, except for some sporadic (probably accidental) benthic diatom valves (Proshkina-Lavrenko, 1963).

The more abundant diatom-bearing sediments in Samples 25-1, 8-9 cm, 24-6, 49-51 cm, 24-6, 21-23 cm, and $8-2,10-12 \mathrm{~cm}$, contained a maximum of up to $167,000,000$ valves/g and an average of $33,000,000$ valves/g. Layers with less abundance contained from $5,000,000$ to $14,000,000$ valves/g, and those with the least content had no more than $5,000,000$ valves/g. The sediments with a diatom content in excess of $33,000,000$ valves/g are to be classed as diatom oozes. The diatom distribution throughout the section of Hole $379 \mathrm{~A}$ is shown in Figure 2. Marine, brackish-water and freshwater halophiles are recognized, but all the marine species are euryhaline forms living in waters of low salinity. Most of the fresh-water diatoms are halophile species capable of withstanding a slight degree of salinity. Warm-water and relatively cold-water species are present.

The following succession of ecological diatom assemblages is observed at Hole $379 \mathrm{~A}$, from bottom to top:

1) Marine and relatively cold-water assemblage with Coscinodiscus normanii as its distinctive species. No such assemblage is known in the present-day population of the Black Sea. We find this assemblage in Sample 29-4 to $25-2,45-47 \mathrm{~cm}$.

2) Brackish-water and fresh-water halophile species assemblage characterized by Stephanodiscus astraea, a species common to the lakes of the Boreal region today. Although it can withstand a salinity as high as $50 / 00$, the assemblage is more frequent in purely fresh-water 


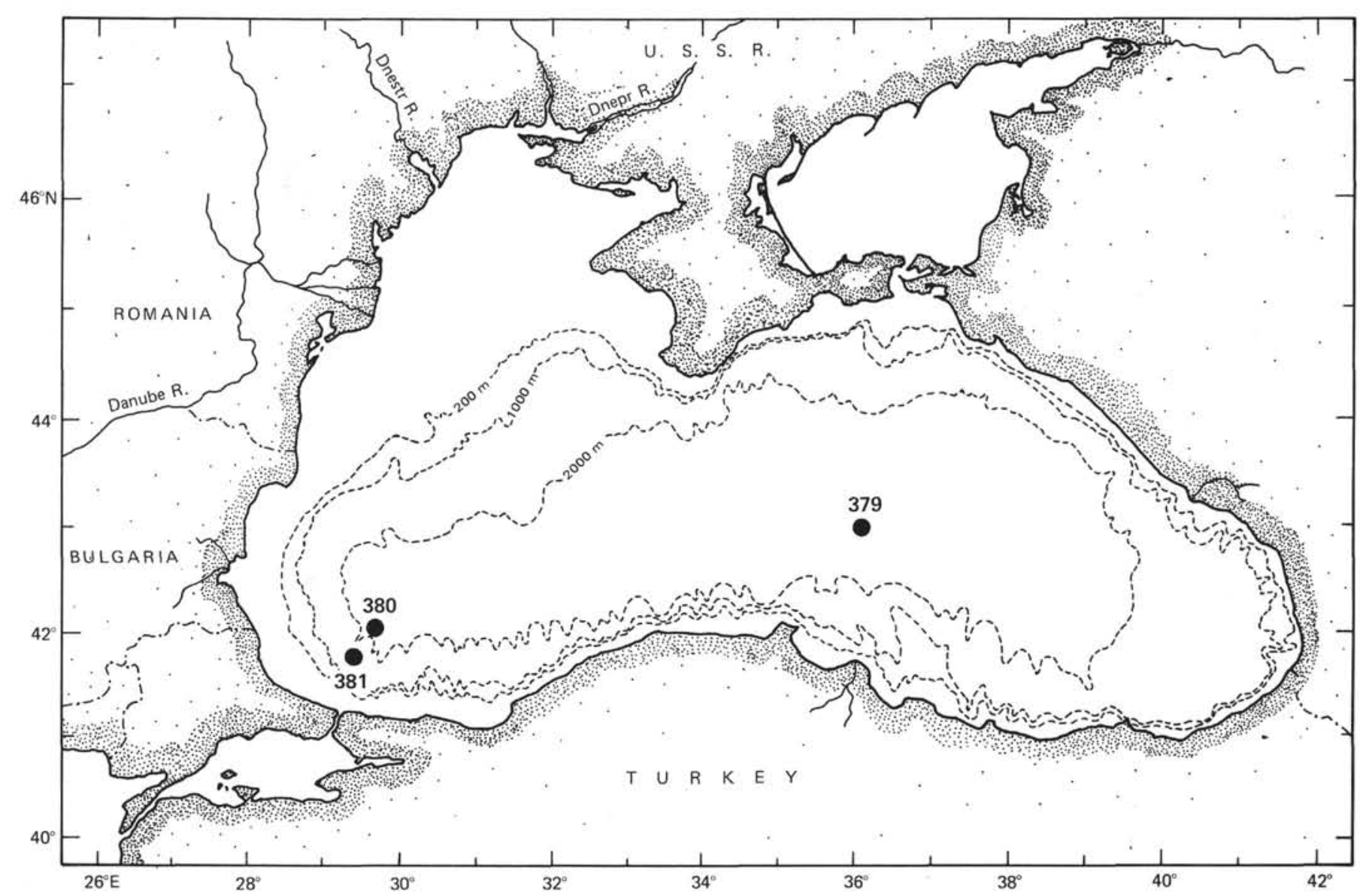

Figure 1. Location of Leg 42B Sites 379, 380, 381.

lakes. It also contains Stephanodiscus gravitoides sp. nov. which does not occur elsewhere in the section. This assemblage is recorded in Samples 25-1, 8-9 cm to 17-1, $25-35 \mathrm{~cm}$.

3) Marine warm-water assemblage entirely free of fresh-water diatoms and consisting of Cyclotella caspia, Thalassiosira aff. oestrupii, Thalassiosira subsalina, Coscinodiscus perforatus, and Chaetoceros spp. It was encountered between Samples 10, CC to 9-2, 10-12 cm. A similar assemblage of marine species is known in the Holocene sediments of the Black Sea (Shimkus et al., 1973).

4) Fresh-water halophile assemblage including brackish-water and sporadic marine diatoms. The relatively cold-water species Stephanodiscus hantzschii and Cyclotella kutzingiana are characteristic of this assemblage. Stephanodiscus astraea is also very abundant. The assemblage is characteristic of Samples $8, \mathrm{CC}$ to $7, \mathrm{CC}$.

\section{Hole 380}

The total number of examined samples is 65 from 27 cores. Samples 39, CC, 38, CC, 29, CC, 25, CC, 20, CC, 13, CC, 9, CC, 5-1, 82-84 cm, 2-5, 88-116 cm, 1-6, 50-52 $\mathrm{cm}$, and $1-5,50-78 \mathrm{~cm}$ were barren of diatoms. Sections $5-4,7-1,7-2,7, \mathrm{CC}, 32-5$, and 32-6 were especially rich in diatoms.

At Site 380 the quantitative and qualitative variations of diatom composition proved to be identical to those at Hole 379A, despite the holes being widely separated.

\section{Hole 380A}

The total number of examined samples from this hole is 94 , obtained from 52 cores. Although 74 cores from Hole 380 were sampled, the interval from Sections 74-2 to 56 , CC contained essentially no diatoms; sporadic benthic species were encountered. Nor were diatoms found within the interval from $31, \mathrm{CC}$ to $18, \mathrm{CC}$. The highest numbers of diatom valves, well in excess of $200,000,000$ to $400,000,000$ valves/g, were recorded in Sections 50-2, 48-6, 45, CC, 45-3, 44, CC, 44-4, 43, CC, $42, \mathrm{CC}, 42-2,42-1,41-6,41-5$, and 38-3. These are typical diatom-oozes. The second numerical gradation is below $200,000,000$ valves/g, but more often it is about $100,000,000$. The quantitative distribution is shown in Figure 4.

The qualitative diatom composition is varied. The following assemblages have been recognized from bottom to top:

1) Marine, relatively warm-water assemblage. Hermisinum adriaticum (family Ebriacea) and Archaeomonodacea are the most characteristic forms, the numbers of which increase toward the base of the marine unit. The marine flora is primarily characterized by Actinocyclus ehrenbergii and its different varieties. This is a sublittoral-neritic species typical of shoreline shallow-water biofacies and common to warm areas. 


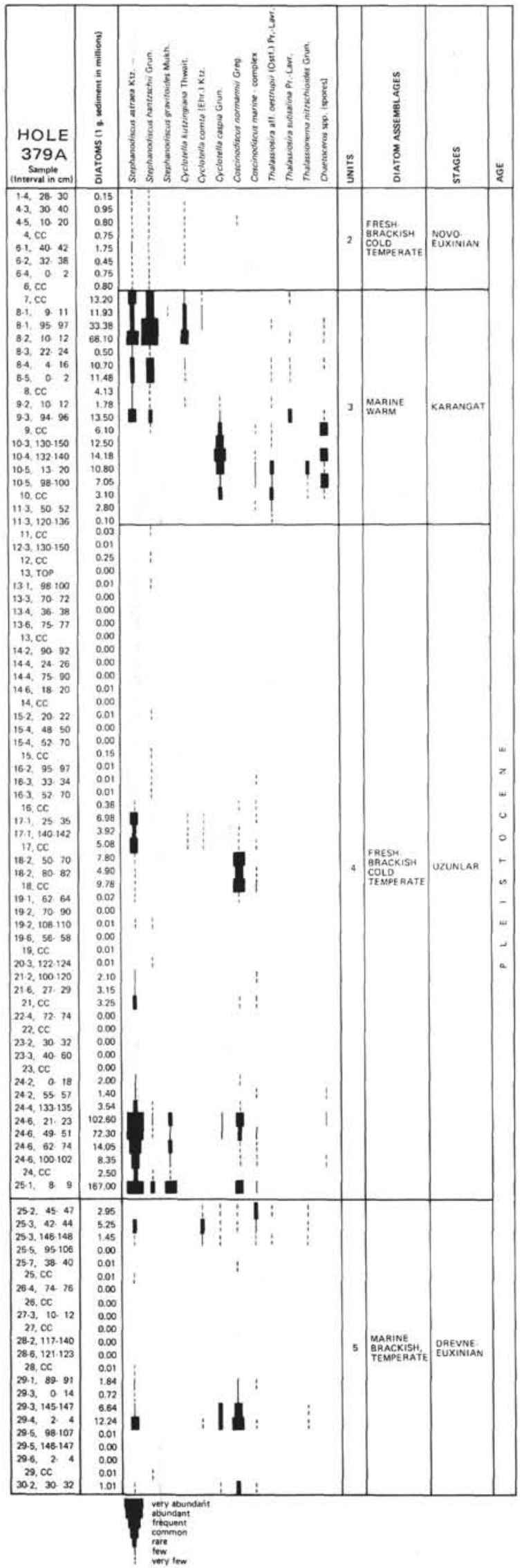

Figure 2. Distribution of diatoms, ebridians, and interpretation of the data, Hole $379 \mathrm{~A}$.

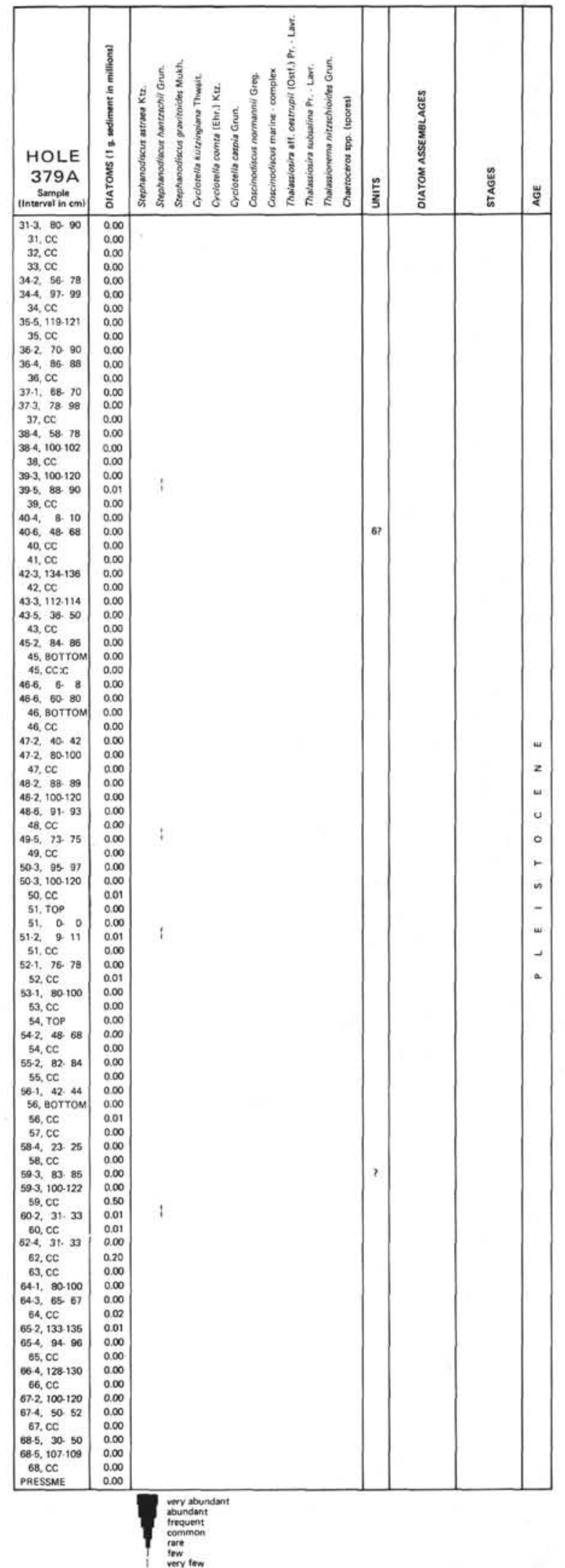

Figure 2. (Continued).

Besides Actinocyclus, the assemblage has the following characteristic species: Rhaphoneis maeotica, Rhizosolenia bezrukovii, Chaetoceros danicus, and 


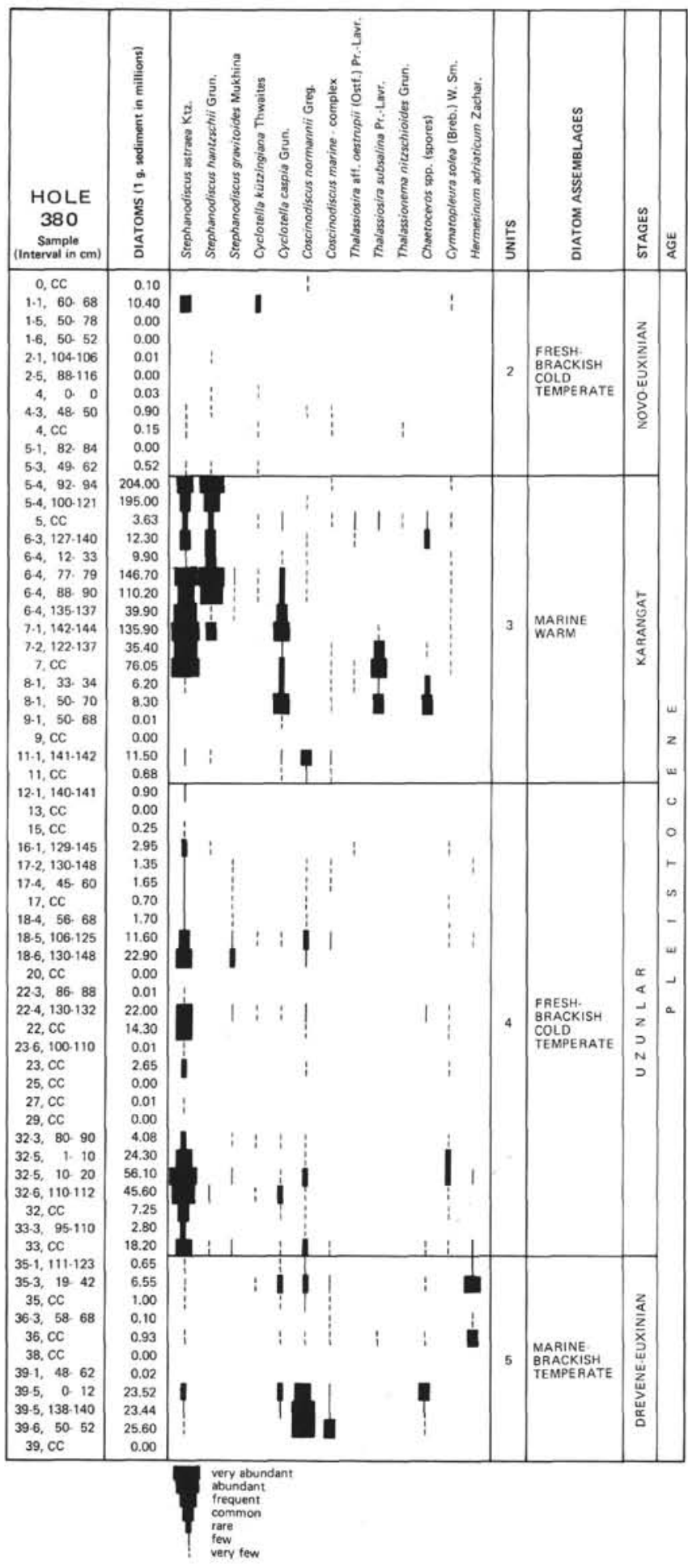

Figure 3. Distribution of diatoms, ebridians, and interpretation of the data, Hole 380.

Cyclotella proshkinae. This assemblage is characteristic of Samples 56, CC to $55-3,55-57 \mathrm{~cm}$.

The interval between Sections 54-1 and Core 50-2 has a mixed fresh-water marine diatom assemblage.

2) From Section $50-1$ to Sample $32-1,6-9 \mathrm{~cm}$ an assemblage of freshwater halophile diatom species prevails. From the diatom composition this thick interval can be regarded as lacustrine in origin.
The diatoms include Melosira, Cyclotella, and Stephanodiscus. The flora appears to be completely extinct except for one questionable species. Melosira includes a large number of archaic Melosira praegranulata and $M$. bellicosa. $M$. praeislandica, $M$. hibschii, M. elegans, and $M$. papilio (the latter two are new species) are markedly fewer in numbers. Stephanodiscus stands out as a special group within this fresh-water assemblage; its evolution is especially rapid and can be divided into four or five successive stages: (1) Stephanodiscus prohantzschii sp. nov.; (2) S. kanitzii; (3) S. pontica sp.nov.; (4) S. dubius; and (5) Cyclotella servant-vildary and its variety var. elegans, which crown the fresh-water close in structure to the members of the genus Stephanodiscus.

3) The third diatom assemblage occurs in Section 3-4 to Sample 1.1, 36-38 cm. The diatom composition of this upper part of Hole $380 \mathrm{~A}$ is similar to that of the base of Holes 380 and 379A Sections 29-4 to 25-2, and can be correlated with the base of the two previous sections. The assemblage contains marine and freshwater halophile species represented by Coscinodiscus normannii, Cyclotella caspia, and Stephanodiscus astraea.

It is to be noted, however, that in Hole $380 \mathrm{~A}$, Samples 17-2, 111-123 cm to 7-1, 50-52 cm, we encountered a diatom assemblage which we had found neither at Hole 379A nor at Hole 380. Besides Stephanodiscus astraea, it also contains Cyclotella corona sp. nov. and, in our opinion, is a fresh-water assemblage.

\section{Site 381}

The total number of 92 samples from 49 cores retrieved from Site 381 were examined. Samples 54-2, $15-16 \mathrm{~cm}$ to $39, \mathrm{CC}$ and $20, \mathrm{CC}$ to $4, \mathrm{CC}$ were found barren of diatoms.

Coccoliths (old) and foraminifers are abundant in Section 40-1. Great amounts of pollen are present in Sample 38, CC, diluting the diatoms; similar layers are found in Sample 56, CC at Hole 380A. In the interval from Sample 38, CC to Core 21, CC typical diatom oozes have a high concentration of diatoms, and in this respect the interval is similar to Hole $380 \mathrm{~A}$, Samples 56$4,77-79 \mathrm{~cm}$ to $38-3,136-138 \mathrm{~cm}$, and $32-1,6-9 \mathrm{~cm}$.

Qualitatively, the site is very much like Hole $380 \mathrm{~A}$. From bottom to top, the marine assemblage (38, CC to $34-6,49-51 \mathrm{~cm}$ ) is followed by an ecologically mixed assemblage, in which brackish-water and fresh-water species (34-3 to 33-4) occur along with marine ones. Further upward (32-1 to 20-1, 110-130 cm), most of the diatoms, of which halophiles prevail, are fresh-water.

The characteristic species of this lacustrine series are Melosira, Cyclotella, and Stephanodiscus. Gyrosigma aff. acuminatum, a very large form, sometimes $200 \mu \mathrm{m}$ long and morphologically different from the presentday form, is also common.

In Sample 3-3, 129-131 cm, Stephanodiscus astraea occurs in large numbers. In the uppermost layers (Samples 1-2, $20 \mathrm{~cm}, 1-3,80 \mathrm{~cm}$ ) the diatom composition can be regarded as marine, in which the northern boreal species Coscinodiscus normannii and the subtropical species Cyclotella caspia and 


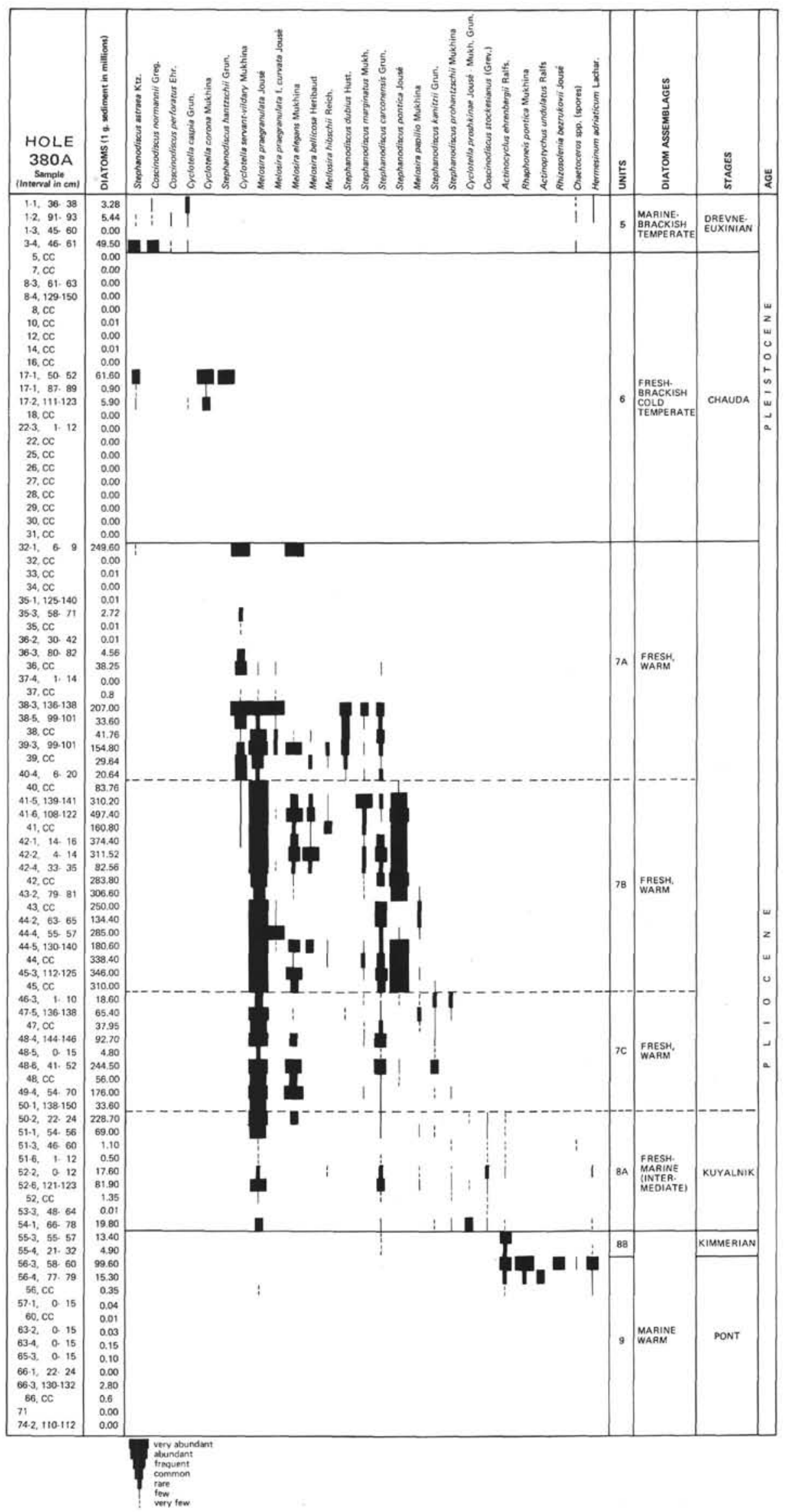

Figure 4. Distribution of diatoms, ebridians, and interpretation of the data, Hole $380 \mathrm{~A}$. 
A. P. JOUSÉ, V. V. MUKHINA

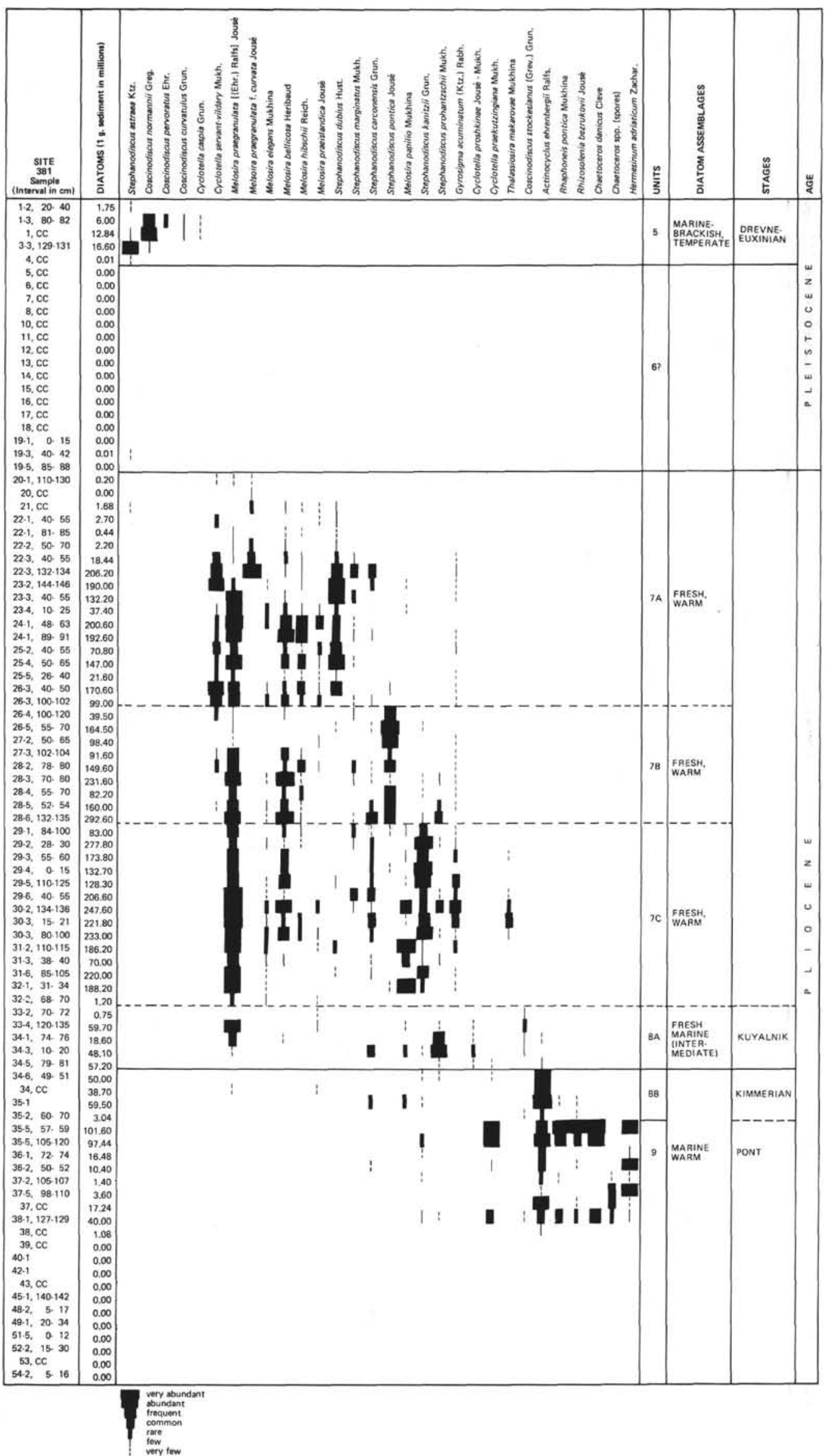

Figure 5. Distribution of diatoms, ebridians, and interpretation of the data, Site 381. 


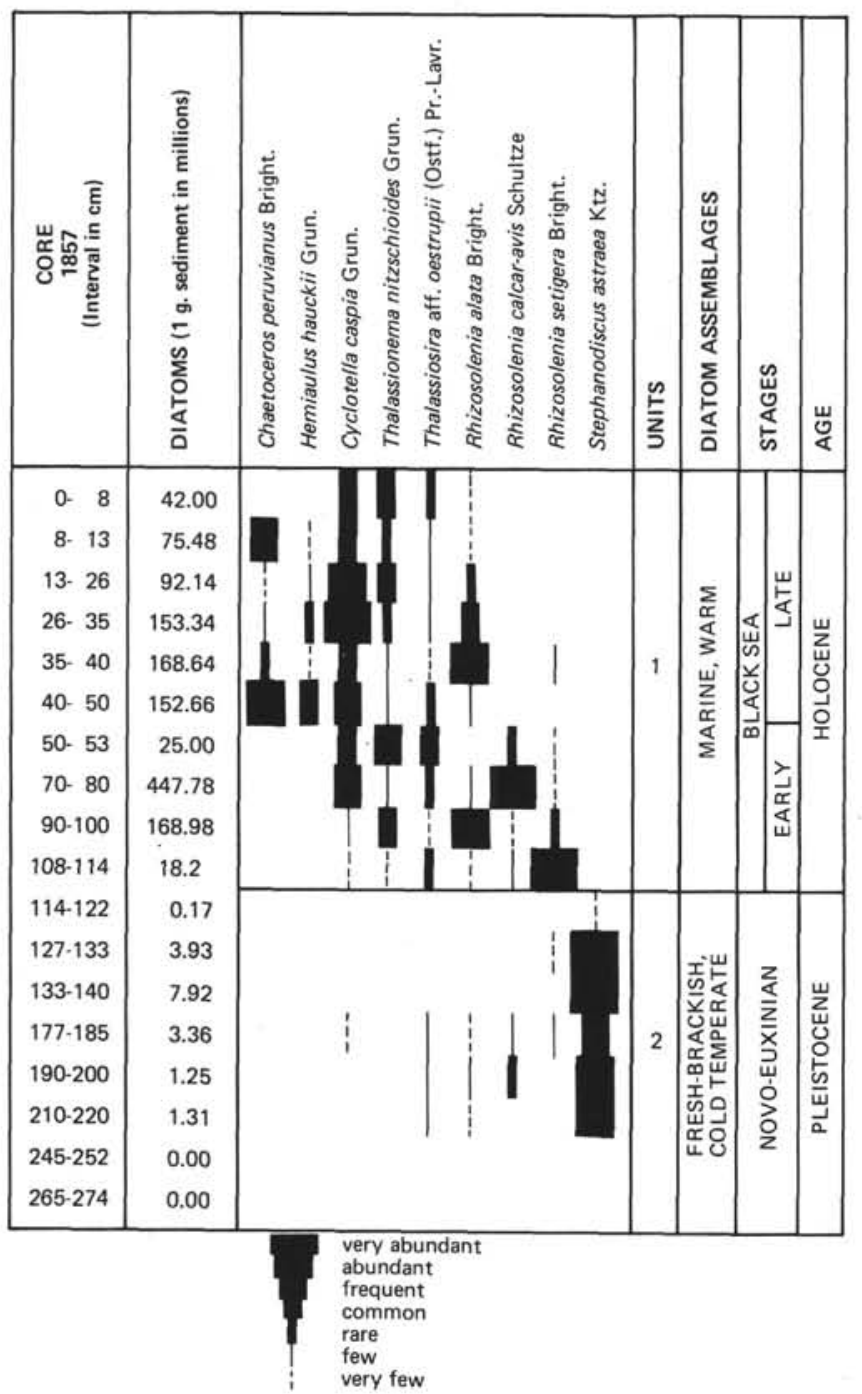

Figure 6. Distribution of diatoms and interpretation of the data, Core 1857.

Coscinodiscus perforatus are predominant, making it similar to Hole 380A, Samples 3-4, 46-61 cm to 1-6, 36$38 \mathrm{~cm}$.

In our opinion, the available data on the youngest Black Sea sediments, dated as Holocene (Shimkus et al., 1973) should be added to the diatom characteristic of the examined sites. Large numbers of diatoms were found in the sediments of Core 1857 off the northwestern continental slope of the Black Sea.

In numbers and species composition, the sediments of the base of core 1857 correlate well with the sediments of the upper layers of Sites 379 and 380 . The abundance in the sediments of these layers is low (no higher than 1,700,000 valves/g) and Stephanodiscus astraea is the most common species. These layers are of fresh water origin.

Marine sediments rich in diatoms (maximum high of $447,800,000$ valves/g of sediment) are present higher in the section. Two stages can be distinguished in the marine sequence: (1) $114-50 \mathrm{~cm}$ with the neritic and neritic-pelagic species Rhizosolenia setigera, Rhizosolenia calcar-avis, Rhizosolenia alata, and
Cyclotella caspia. (2) $50-0 \mathrm{~cm}$ mostly with pelagic warm-water species such as Chaetoceros peruvianus, Hemiaulus hauckii, and Thalassionema nitzschiodes, which probably appeared as a result of free water exchange with the Mediterranean Sea.

Silicoflagellates, with the species Distephanus octonarius var. polyactis occurring in large numbers (up to $35,000,000$ valves $/ \mathrm{g}$ ) is, besides diatoms, characteristic of the Holocene sediments of the Black Sea.

\section{BIOSTRATIGRAPHY AND \\ PALEOGEOGRAPHICAL ENVIRONMENTS OF SEDIMENTATION}

On the basis of diatom composition, the succession of Pliocene-Holocene sediments in the Black Sea can be readily subdivided into eight units representing alternating episodes of marine-brackish and freshwater subsaline conditions. Cool-water and warmwater periods in the history of sedimentation are less easily recognized. Diatoms enable us to define accurately the Pliocene-Pleistocene boundary at the top of a lacustrine sediment unit which contains fossil fresh-water diatoms belonging to Melosira, Cyclotella, and Stephanodiscus as characteristic species.

Unit 8, the oldest encountered unit of marine origin, occurs at the base of the diatom-bearing series at Hole $380 \mathrm{~A}$ (Cores 56-55) and Site 381 (Sections 34-6 to 38-1). We treat Unit 8 as Pontian on the basis of similarities between the diatom assemblages and the pontic flora of the Taman Peninsula (Jousé, 1949). ${ }^{1}$ The presence of older marine sediments remains problematic in that at Site 381 (Sections 37-2, 37-5 Sample 38-1, $127 \mathrm{~cm}$ ) large numbers of Raphoneis maeotica, Archaeomonos spp. and Hermisinum adriaticum occur, suggesting a Meotian age.

Unit 7: Above marine Unit 8 is a sedimentary series of lacustrine origin characterized by fresh-water and fresh-water halophilic diatoms. It is more than 200 meters thick at Hole 380A (Cores 54-32) and 140 meters at Site 381 (Sections 34-3 to 20-1). The deposition of Unit 7 took place in late Pliocene when the Black Sea became isolated from the Mediterranean Sea and began changing into a lake-sea.

Throughout the depositional period of Unit 7 the diatom floral composition changed frequently, affecting mostly Stephanodiscus and Cyclotella; most of Melosira spp. remained unchanged. Diatoms of Unit 7 include many new species, descriptions of which are given in the Systematics section. Diatoms flourished during the whole of the lacustrine period probably because of rich biogenic elements that ascended into the euphotic zone from the depth. As a result, siliceous oozes characterize the sediments of Unit 7.

Lacustrine sediments of the Pliocene-Miocene, elsewhere in Europe are older than to those of the Black Sea. The lacustrine floras of Central Europe (Hungary,

\footnotetext{
'In accordance with the latest stratigraphical scheme adopted at Bratislava in 1975, the Pontic stage corresponds to the close of the late Miocene (Messinian stage)-early Pliocene. It is not impossible that the layers containing Hermisinum adriaticum and cysts Archaeomonadaceae are already of the Meotis.
} 
Austria, and Czechoslovakia) are much older, usually not younger than late Miocene (Reichert, 1899-1900; Hajos and Gyula, 1969); Hajos and Holzer, 1972; Rehakova, 1965, 1975). Rehakova (in a personal report) refers to the lacustrine biofacies of the late Miocene age in southern Czechia, which she calls the Stephanodiscus formation. The only locality similar in age to the Black Sea diatom floras is Lake Chad, the Pliocene sediment of which contain some Black-Sea species such as Melosira praegranulata, Cyclotella servant-vildary sp. nova, and Stephanodiscus carconensis (Servant-Vildary, 1973). There is also some similarity with the lacustrine Pliocene floras of France (Ehrlich, Ehrlich, 1967).

For all the possible analogies, however, the flora of the Black Sea as a whole is unusual and, indeed, endemic in some of its elements; the great number of new species is one evidence in this respect.

The evolution of diatoms was conspicuous during the Pliocene lacustrine stage of the Black Sea, and is particularly traceable in the evolution of Stephanodiscus, which numbers more than 10 species and several varieties. Because some Stephanodiscus species had a short time span, it is possible to subdivide the lacustrine series into four zones (from bottom to top): (1) Stephanodiscus prohantzschii, (2) Stephanodiscus kanitzii, (3) Stephanodiscus pontica, and (4) Stephanodiscus dubius. The series is crowned with layers containing Cyclotella servant-vildary and its variety elegans. In the summary stratigraphic tables (Figures 7 and 8 ) the stages are marked by the letters A, B, C, D.

The diversity of the taxonomic composition within certain intervals in Unit 7 is low; a single species may account for $80 \%$ to $90 \%$ of the total number of diatoms in some samples.

The upper part of lacustrine Unit 7 shows a gradual disappearance of the old species assemblage and it is on the basis of the last of its elements that we define the Pliocene-Pleistocene boundary.

Unit 6 succeeds the Pliocene-Pleistocene boundary. It is a thick terrigenous series at Holes 379A, 380, and Site 381 , entirely barren of diatoms. The only exception is in the sediments of Hole 380A, Sample 17-2, 111-123 $\mathrm{cm}$ to $17-1,50-52 \mathrm{~cm}$, where an assemblage of diatoms with the hitherto unknown form Cyclotella corona sp. nov, as the most common species and with Stephanodiscus astraea and Stephanodiscus hantzschii in much less numbers occurs. Although Holes 379A and 380 were penetrated to 624.5 and 380 meters, respectively, they did not reach the lower boundary of sediments of Pleistocene age. On the basis of its stratigraphic position, Unit 6 is most likely of early Pleistocene age.

A complete change of the ecological environments at the close of the lacustrine period resulted in a prolonged retardation of evolution of the Black-Sea diatoms. Variation in the salinity of the basin, decrease in temperature due to the onset of the cold period, or a lack of nutritive salts in the surface waters were likely factors that contributed to, or were responsible for, the essential absence of diatoms in Unit 6.

Unit 5 is recognized at all Black Sea holes drilled by Glomar Challenger. At Hole 379A, it occurs in Samples $30-2,30-32 \mathrm{~cm}$ to $25-2,45-47 \mathrm{~cm}$, at Hole 380 , in

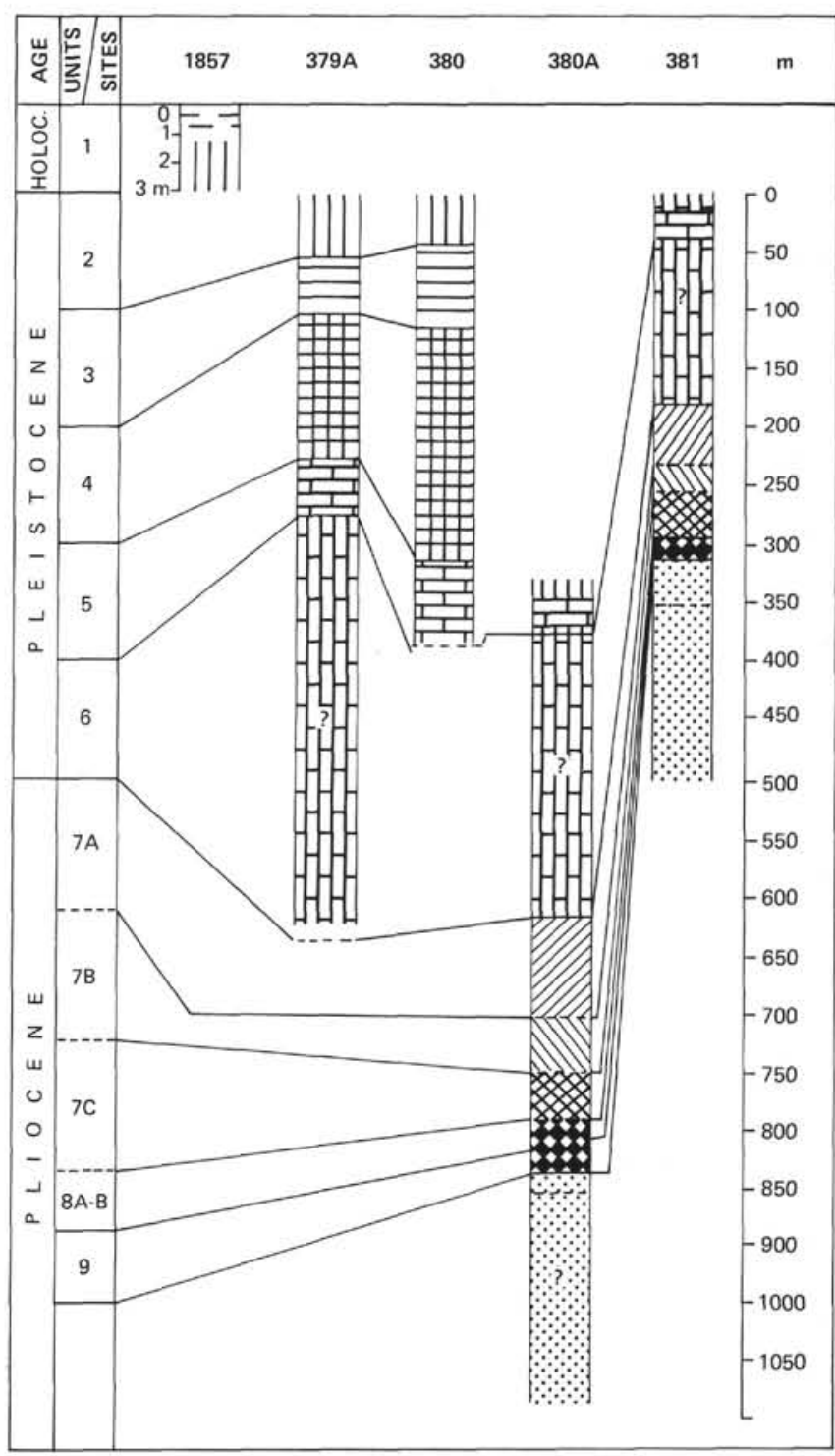

Figure 7. Correlation of the diatom units of the Black Sea.

Samples 39-6, 50-52 cm to $35-1,111-123 \mathrm{~cm}$, at Hole $380 \mathrm{~A}$, in Samples 3-4, $46-61 \mathrm{~cm}$, to $1-1,36-38 \mathrm{~cm}$ and at Site 381, in Samples 4, CC to $1-2,20-40 \mathrm{~cm}$; Unit 5 is at the top of the drilled sediments of the latter two sites.

Most of the diatoms within Unit 5 are marine species, but fresh-water and brackish-water species are also in considerable numbers. Coscinodiscus normannii, a boreal, relatively cool-water marine species is very abundant, and can be taken as the index species.

According to the stratigraphic scheme of the Quaternary Period of the Black Sea basin proposed by Arkhangelskiy and Strakhov (1938), Unit 5 correlates well with the Drevne-euxinian (Fedorov, 1963).

Unit 4 is a thick unit occuring at Hole $379 \mathrm{~A}$ in Samples 25-1 to 11, CC, and at Hole 380, in Samples 33 , CC to $12-1,140-141 \mathrm{~cm}$.

The diatom distribution makes it possible to distinguish within Unit 4, at Hole 379A, the following stratigraphic intervals. At the base, from $25-1,8-9 \mathrm{~cm}$ to $24-4,133-135 \mathrm{~cm}$, there is a maximum of $167,000,000$ valves/g; in the second layer, $24-4,133-135 \mathrm{~cm}$, to $19-1$ 


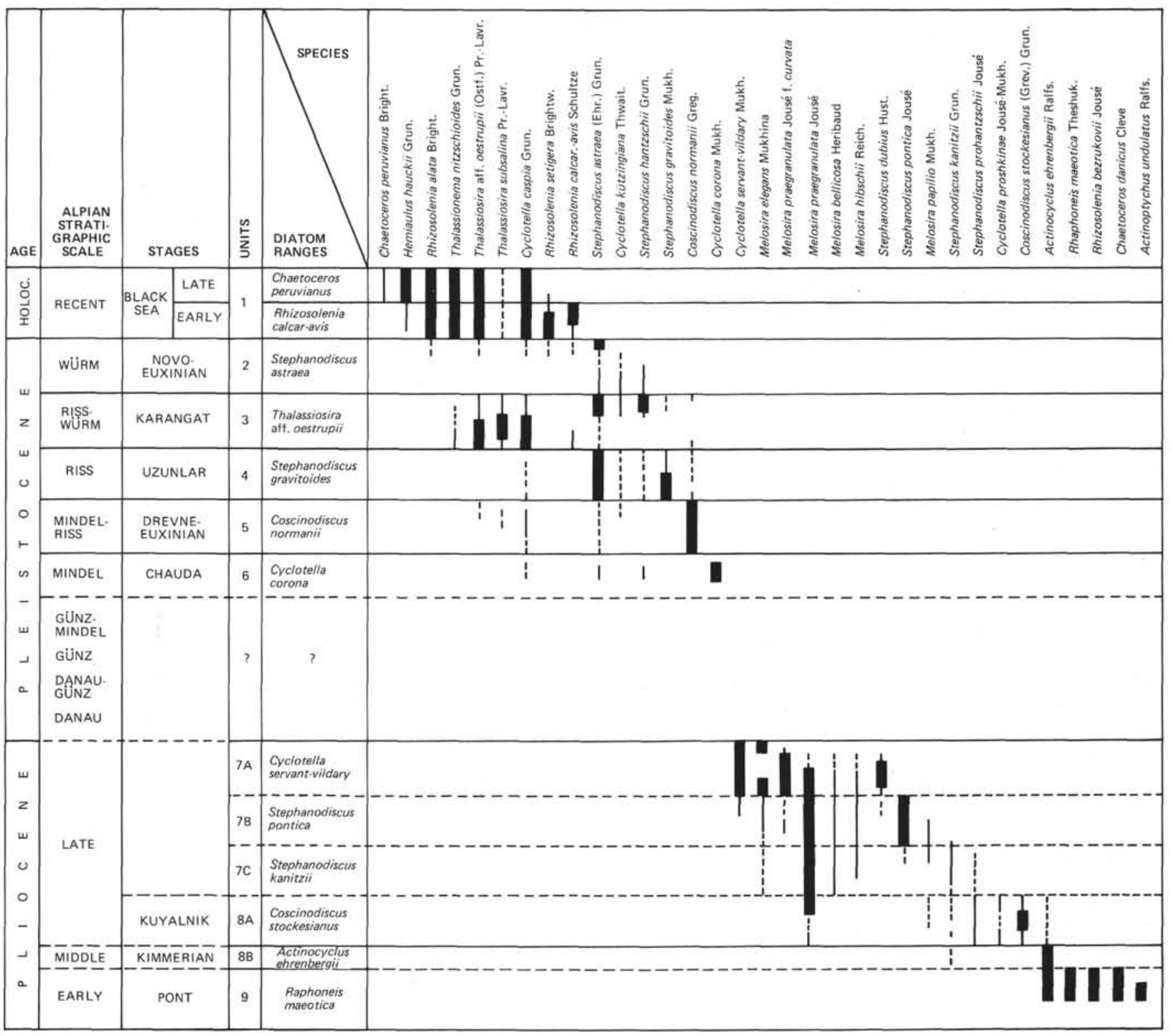

Figure 8. Correlation of the diatom data at Black Sea and Alpian stratigraphic scale.

the overall number of diatoms does not exceed $3,000,000$ valves/g; in the third layer, 18, CC to $17-1$, $25-35 \mathrm{~cm}$, there are approximately $10,000,000$ valves/g; and in the fourth layer, 16, CC to $11, \mathrm{CC}$ diatom valves are rare and occur sporadically in individual samples.

A similar abundance curve is found for Site 380 .

The diatom flora of Unit 4 is mostly fresh water with some brackish-water and marine species. Consequently, it is postulated that a fresh-water basin existed during the depositional period of Unit 4, and climatic conditions changed repeatedly with warm stages charcterized by a high diatom productivity (layers I and III) alternating with cooler stages during which the productivity was low (layers II and IV).

According to the stratigraphic scheme of the Quaternary period of the Black Sea basin, Unit 4 combines Paleouzunfar and Uzunlar sediments.

Unit 3 is readily identified by a definite Pleistocene marine diatom flora. The marine flora is especially characteristic of, and abundant in, the lower part of the unit (Hole 379A, Samples 10, CC to 9-3, 94-96 cm), but toward the upper boundary the marine assemblage diminishes and fresh-water and brackish-water diatoms become abundant. This fresh-water assemblage is common to Hole 379 A, Samples $9-2,10-12 \mathrm{~cm}$ to 7 , $\mathrm{CC}$, and to Hole 380 .

The marine assemblage is characterized by the presence of such warm-water species as Thalassiosira aff. oestrupii, Thalassiosira subsalina, Coscinodiscus perforatus, Cyclotella caspia, Chaetoceros spp. (spores). Thalassiosira oestrupii has not been recognized in the present-day population of the Black Sea (ProshkinaLavrenko, 1955), although it existed in the Holocene (Shimkus et al., 1973).

In diatom characteristics, Unit 3 correlates well with the paleogeographical environments of the Karangat interglacial epoch (Eemian in Western Europe or Mikulino in the territory of the USSR) (Markov et al., 1965; Arslanov et al., 1976).

Unit 2 combines the series of sediments of Hole 
379 A, Samples $6, \mathrm{CC}$ to $1-4,28-30 \mathrm{~cm}$ and Hole 380 , Samples 5-3, 49-62 cm to 0, CC with the base of Core 1957 in the interval of 265 to $114 \mathrm{~cm}$.

Unit 2 is deficient in diatom remains; none in fact were found in some of the samples. Of the species encountered, the fresh-water Stephanodiscus astraea was most frequent.

On the basis of species composition and quantitative distribution of the diatoms of Unit 2, we are able to relate the unit to the last glacial epoch (Würm, Valdaj). Following the stratigraphic scheme of the Pleistocene of the Black Sea, Unit 2 corresponds to the Novoeuxinian epoch.

The paleogeographical conditions of deposition of Unit 2 are similar to those of Unit 6.

Unit 1 is identified on the basis of diatom evidence in Core 1857, as being Holocene. The diatoms are marine and the species composition is close to the present-day Black Sea flora.

\section{CONCLUSIONS}

1. In this first opportunity to study the late Tertiary diatom assemblages of the Black Sea, it has become apparent that, during the Pleistocene a regular alternation of fresh-water species assemblages deposited during the cold epochs, with brackish-water marine and marine species deposited during the warm epochs occurred. The warmest and most dominant marine assemblage of diatoms corresponds to the Karangat (Riss-Würm). In the intervals correlating with the cold epochs the diversity and abundance of diatoms fall sharply.

The Pliocene-Pleistocene boundary is readily recognizable by the extinction of old (on the whole fossil) fresh-water diatoms.

2. In the late Pliocene the Black Sea was a vast lake in which sediments of the diatom ooze type accumulated. The vertical distribution of diatoms during the late Pliocene shows four stages of evolution. The earliest is characterized by a fresh-water and brackish-water diatom flora and is regarded as a transitional stage. The next three stages represent lacustrine environments; diatoms within them include members of the three genera Melosira, Cyclotella, and Stephanodiscus which are common representatives of a lacustrine flora.

3. Below the lacustrine diatom series of the late Pliocene sediments are clayish marine sediments. They are characterized by a planktonic diatom flora with Actinocyclus, Rhaphoneis, Chaetoceros, Rhizosolenia, Actinoptychus, and Cyclotella as type genera, and diverse benthic marine species. Besides diatoms, the marine series at the base of Hole $380 \mathrm{~A}$ and Site 381 is characterized by large numbers of Hermisinum adriaticum, a member of the family Ebriacea, and spores of the Archaeomonodacea type. Proceeding from the great similarity between the diatom composition in the sea sediments examined and that of the known show pontic sediments (the Taman Peninsula), we correlate this marine series containing Actinocyclus ehrenbergii to the Pontian Maeotian stage.

The Stratigraphical scheme we are proposing for the Pliocene-Pleistocene sediments of the Black Sea is to be regarded as tentative and demands further elaboration, since we have no data on the absolute age of the sediments and on the paleomagnetic stratigraphy.

\section{SYSTEMATICS}

Coscinodiscus normannii Greg.

(Plate 16, Figures 1-10; Plate 18, Figures 1-6, 10-12)

Description: Jousé, Diatomic Analysis (1949), p. 63, pl. 19, fig. $4 a-b$.

DSDP Leg 42B occurrences: Found in varying abundance in the Pleistocene sections of Holes $379 \mathrm{~A}$ and 380 .

\section{Coscinodiscus aff. stokesianus (Grev.) Grunow}

(Plate 4, Figures 7-9)

Description: Rehakova (1965), p. 30, pl. IX, fig. 3-7.

DSDP Leg 42B occurrences: Found abundant to common in the early Pliocene sections of Holes 380A (Cores 51-54) and 381 (Cores 33-34).

\section{Cyclotella caspia Grunow}

(Plate 19, Figures 6-9; Plate 20, Figures 9, 10; Plate 22, Figure 8)

Description: Proshkina-Lavrenko (1955), p. 61, pl. II, fig. 1-8.

DSDP Leg 42B occurrences: Found in varying abundance in the Pleistocene sections of Holes 379A, 380, and in the Holocene sections of Core 1857.

\section{Cyclotella corona Mukhina sp. nov. \\ (Plate 15, Figures 2-10)}

Description: Valve thick-walled, convex, 25-35 $\mu \mathrm{m}$ in diameter. The marginal zone is about two-thirds of the radius in width, with radial striae becoming furcate at the edge. The marginal zone is often fracturable. The central area is large, clearly bounded and raised over the marginal zone, at times irregular. A ring of large punctae near the edge of the central area; at times two or three punctae at the center of the area.

DSDP Leg 42B occurrences: Fresh-water species, early Pleistocene. Hole 380A, Sample 17-1, 50-52 cm-abundant; Sample $17-1,87-89 \mathrm{~cm} ; 17-2,111-123 \mathrm{~cm}$-common.

Holotype: Plate 15, Figure 5; from Leg 42B, Sample 380A, 17-2, $111-123 \mathrm{~cm}$, Black Sea.

Paratype: Plate 15, Figures 2-4, 6-10.

\section{Cyclotella proshkinae Jousé et Mukhina sp. nov.}

(Plate 3, Figures 5-11; Plate 4, Figure 12)

Description: Valves small, 5-10 $\mu \mathrm{m}$ in diameter. A transverse plication is sometimes visible. The middle part of the valve is thickly granular. The margin narrow (often fractured), finely striated, and visible at magnification 2000-3000 in SEM.

Remarks: zespecies istnametin.honor of A. I. ProshkinaLavrenko; a well-known scientist of the Black Sea diatoms.

DSDP Leg 42B occurrences: Brackish-water species; early Pliocene. Hole 380A, Cores 33-34, common.

Holotype: Plate 4, Figure 12; from Leg 42B, Sample 380A-54-1, $66-78 \mathrm{~cm}$, Black Sea.

Cyclotella kutzingiana Thwaites

(Plate 19, Figure 12; Plate 20, Figures 1-8)

Description: Hustedt (1930), p. 338, pl. 1, fig. 171.

DSDP Leg 42B occurrences: Found in varying abundance in the Pleistocene sections of Holes $379 \mathrm{~A}$ and 380 .

\section{Cyclotella praekutzingiana Mukhina sp. nov.} (Plate 3, Figures 5-11)

Description: Valves flat or slightly convex, at times with a tangential plication, from 5 to $18 \mu \mathrm{m}$ in diameter. The marginal zone often wide, from one-third to one-half of the valve diameter. The surface of the marginal zone is finely striated; striae vary in length. The middle part of the valve is finely granular. A smooth hyaline zone is often present between the striated peripheral zone and the granular middle zone. The margin has one process. This species is similar to Cyclotella kutzingiana from Lake Hula of Northern Israel (Ehrlich, 1973).

DSDP Leg 42B occurrences: Brackish-water marine species. Early Pliocene (Pontian stage). Hole 380A, Core 55, few; Hole 381, Cores 35,38 , abundant. 
Holotype: Plate 3, Figure 5; from Leg 42B, Sample 381-35-5, $105-$ $120 \mathrm{~cm}$, Black Sea.

Paratype: Plate 3, Figures 6-11.

Cyclotella servant-vildary Mukhina sp. nov.

(Plate 8, Figure 1; Plate 10, Figures 5-15; Plate 11, Figures 1-2, 4-11, Plate 14, Figures 3-4, 7-8)

Description: Valves flat, 5-30 $\mu \mathrm{m}$ in diameter. The margin is well pronounced, very narrow $(2-3 \mu \mathrm{m})$, finely striated, often fracturable. Rare radial rows of large areolae occur on the surface of the valve. The number of the rows depends on the valve diameter (varying from 6 to 15 around the circumference). No spines are present.

Remarks: The species shows a high degree of polymorphism. It is identical with Cyclotella sp. (Servant-Vildary, 1973, pl. 10, fig. 1-3) from the sediments of Lake Chad.

DSDP Leg 42B occurrences: Fresh-water species; late Pliocene. Hole $380 \mathrm{~A}$, Cores $32-40$, abundant. Hole 381, Cores 22-26, common.

Holotype: Plate 1I, Figure 9: from Leg 42B, Sample 380A, 35-3, $(58-71 \mathrm{~cm})$, Black Sea.

Paratype: Plate 8, Figure 1; Plate 10, Figures 5-15. Plate 11, Figures 1-2, 4-8, 10-11; Plate 14, Figures 3-4, 7-8.

C. servant-vildary var. elegans var. nov.

(Plate 8, Figure 2; Plate 10, Figures 1-4; Plate 11, Figure 12; Plate 14, Figures 1-2)

Remarks: Differs from the type in that margin is broader and the rows of areqlae have a fine, more dense structure; $15 \mu \mathrm{m}$ to $20 \mu \mathrm{m}$ in diameter on the average.

DSDP Leg 42B occurrences: Found together with the species; the vertical range is short. Hole $380 \mathrm{~A}$, Sample $32-1,6-9 \mathrm{~cm}$, abundant.

Holotype: Plate 10, Figure 1; from Leg 42B, Sample 380A-32-1, 6$9 \mathrm{~cm}$, Black Sea.

Paratype: Plate 8, Figure 2; Plate 10, Figures 2-4; Plate 11, Figure 12; Plate 14, Figures 1-2

\section{Gyrosigma aff. acuminatum (Ktz.) Rbh.}

Description: Jousé, Diatomic Analysis (19549), 248, pl. 80, fig. 9

Remarks: Valve linear, narrowing slightly toward the apices. 200$400 \mu \mathrm{m}$ long and about $20 \mu \mathrm{m}$ wide. The axial area and raphe are thread-like. The central area is very small and the central nodule hardly visible. The striae transverse, linear, 20-22 in $10 \mu \mathrm{m}$. Commonly there are longitudinal striae, but often they are absent.

DSDP Leg 42B occurrences: Fresh-water-subsaline-water species. Hole 380A, Cores 38-41, rare. Hole 381, Cores 29-31, common. No illustration.

\section{Melosira bellicosa Heribaud}

(Plate 6, Figure 15; Plate 12, Figures 10, 12-15)

Description: Heribaud (1903), p. 93, pl. 12, fig. 23.

Remarks: Valves cylindrical, diameter and height approximately equal; $8-10 \mu \mathrm{m}$ in diameter, $7-10 \mu \mathrm{m}$ in height. At the base of the valve there is a deep sulcus which separates a hyaline broad collar. Longitudinal ridges cross the valve surface, with rare elongate areolae scattered between the ridges. Spines are arranged around the valve disk.

Resting spores of this species are also found in the sediments, They have dome-shaped valves and a very broad band. The valves differ in structure; the structure of one is more rarified and finer than that of the other.

Typical $M$. bellicosa is known from the late Pliocene of France (Heribaud, 1903), Ehrlich (1967) in Villafranch.

DSDP Leg 42B occurrences: Fresh-water species. Found together with Melosira praegramulata and Melosira hibschii. Occurs in varying abundance in the late Pliocene section of Holes $380 \mathrm{~A}$ and 381 .

\section{Melosira elegans Mukhina sp. nov.} (Plate 9, Figures 5-7)

Description: Frustule cylindrical, thin-walled, 30-35 $\mu \mathrm{m}$ high. Valves $10-13 \mu \mathrm{m}$ in diameter, often widened at the ends. The free end of the valve has a narrow hyaline collar. The sulcus is hardly visible, the joint of the valves is very tight, with minute denticles between the valves. Valve areolate. Areolae flat, tightly adjoining one another, light colored, arranged in regular rows, 12 rows of areolae in $10 \mu \mathrm{m}$.
DSDP Leg 42B occurrences: Always found together with Melosira praegranulata and Melosira bellicosa, but in less numbers. Freshwater species; late Pliocene. Holes $380 \mathrm{~A}, 381$, abundant.

Holotype: Plate 9, Figure 5; from Leg 42B, Sample 380A-39-3, 99 $101 \mathrm{~cm}$, Black Sea.

Paratype: Plate 9, Figures 6. 7.

Melosira hibschii Reichert

(Plate 6, Figure 16; Plate 12, Figures 2, 3, 6, 7)

Description: Rehakova (1969), pl. 2, Fig. 34-37.

Remarks: Frustules and valves of vegetative cells, as well as resting spores having a barrel-shaped form and dome-shaped valves. Vegetative cells have flat valves. Dome-shaped valves and flat valves are equal in size; $18-20 \mu \mathrm{m}$ in diameter and $15 \mu \mathrm{m}$ high. Shallow sulcus separates a hyaline band. Valve disk thickly areolate, areolae varying in size. Over the edge of the disk there is a ring of elongate large areolae similar in form to the areolae at the valve fold.

DSDP Leg 42B occurrences: Fresh-water species. Encountered together with Melosira praegranulata. Found in varying abundance in the late Pliocene sections of Holes $380 \mathrm{~A}$ and 381

\section{Melosira papilio Mukhina sp. nov.}

(Plate 5, Figures 1, 2, 11-14)

Description: Valves small, bell-shaped, 5-6 $\mu \mathrm{m}$ high. Jointed with a broad girdle with numerous intercalary bands. The structure is finely porous. Often the valves are covered with minute spines. One process is near the sulcus. Valves form short curved chains.

DSDP Leg 42B occurrences: Brackish-water fresh-water species. Characteristic of the early stage of the late Pliocene. Holes $380 \mathrm{~A}$, Cores 43-47; 381, Cores 29-35.1, common.

Holotype: Plate 5, Figure 1; from Leg 42B, Sample 381, 32-1, 31$34 \mathrm{~cm}$, Black Sea

Paratype: Plate 5, Figures 2, 11-14.

Melosira praegranulata Jousé

(Plate 5, Figures 3-9; Plate 9, Figures 8, 9; Plate 12, Figures 8, 9, 11)

Description: Jousé (1952), p. 24l, pl. 3, fig. 8, 9.

Remarks: The species shows a high degree of polymorphism. Servant-Vildary (1973) refers to the presence of ocelles on the valve of $M$. praegranulata, which, when viewed in optical microscope, look like a ring $2 \mu \mathrm{m}$ in diamter near the sulcus on the outside surface of the valve, which seems to open into the interior of the valve. This element of the structure has not been found in our material.

DSDP Leg 42B occurrences: Fresh-water, probably halophile species. One of the most characteristic and massive in the Melosire assemblage during the late Pliocene Holes $380 \mathrm{~A}$, Cores $36, \mathrm{CC}$ to $54-$ 1; 381 , Cores 20 to $34-3$.

\section{M. praegranulata f. curvata Jousé}

(Plate 9, Figures 10-16)

Description: Jousé (1952), p. 241, pl. 3, fig. 9.

DSDP Leg 42B occurrences: Found together with the species..The vertical range is restricted. Sites $380 \mathrm{~A}$, Cores $36-39 ; 381$, Cores $20-22$, Section 3, common.

\section{Melosira praeislandica Jousé}

(Plate 5, Figure 10)

Description: Jousé (1952), p. 241, pl. 3, fig. 1-2, 5 .

DSDP Leg 42B occurrences: Fresh-water halophile species. Common in the late Pliocene section of Holes $380 \mathrm{~A}$ and 381 . Diatoms of the USSR, v. 1 , pl. 44 , fig. 3

\section{Rhaphoneis maestica (Milovanova) Sheshuk and Gleser}

(Plate 2, Figures 8-14)

Description: Valves linear, straight and curved, at times slightly widened at the ends and in the middle, 20-70 $\mu \mathrm{m}$ long and 2-4 $\mu \mathrm{m}$ wide. The axial area is thread-like. The pores form regular transverse rows, 16 rows in $10 \mu \mathrm{m}$. Some forms have a thick meshwork of minute pores at the poles of the valves. Form chain colonies.

DSDP Leg 42B occurrences: Marine species; early Pliocene (Pontian-Maeotian stage). Hole 380A, Core 56; 381, Cores 35, 38, abundant. 
Holotype: Plate 2, Figure 9; from Leg 42B, Sample 381-35-5, 105$120 \mathrm{~cm}$, Black Sea.

Paratype: Plate 2, Figures 8, 10-14.

Rhizosolenia bezrukovii Jousé sp. nov.

(Plate 1, Figures 12-13)

Description: Frustule cylindrical, from 6 to $22 \mu \mathrm{m}$ in diameter Valve funnel-shaped turning into a very long, thin process 100-200 $\mu \mathrm{m}$ in length. The process is either straight or curved, slightly tapering toward the free end. The surface of the process is finely granular. Two transparent setulae protrude from the valve disk. The valve surface is smooth. The numerous intercalary bands of the frustule are collarshaped.

Remarks: The species is named in honor of Professor P.L. Bezrukova, marine geologist and sedimentologist.

DSDP Leg 42B occurrences: Marine species; early Pliocene (Pontian Stage). Holes 380A, Core $56.3 ; 381$, Core 35.5 , abundant.

Holotype: Plate I, Figure 12; from Leg 42B, Sample 381, 35-5, 57 $59 \mathrm{~cm}$. Black Sea.

Paratype:Plate 1, Figure 13.

Stephanodiscus astraea (Ehr.) Grunow

(Plate 15, Figure 1; Plate 17, Figures 4-10; Plate 20, Figures 12-13; Plate 21, Figures 1-3; Plate 22, Figure 2)

Description: Hustedt (1930), p. 368-369, fig. 193.

DSDP Leg 42B occurrences: Found in varying abundance in the Pleistocene sections of Sites 379A, 380 and in some samples in the Holocene section of Core 1857.

Stephanodiscus carconensis Grunow

(Plate 2, Figures 1-4; Plate 3, Figures 12-13; Plate 4, Figures 1-4: Plate 13, Figures 10-12

Description: Servant-Vildary (1973), pl 367-368, fig. 192.

DSDP Leg 42 occurrences: Found abundant in the late Pliocene sections of Holes $380 \mathrm{~A}$ and 381 .

\section{Stephanodiscus gravitoides Mukhina sp. nov.} (Plate 17, Figures 11-12)

Description: Valve greatly convex, 22.5-37 $\mu \mathrm{m}$ in diameter. Areolae arranged in radial rows, 10 areolae in $10 \mu \mathrm{m}$ near the center and 12 areolae in $10 \mu \mathrm{m}$ at the edge. The center is at times lacking structure. Single rows of areolae near the edge turn into double rows. The margin area narrow, porous, with rare spikes, 2 spikes in $10 \mu \mathrm{m}$.

DSDP Leg 42B occurrences: Fresh-water halophil species. Quaternary. Hole $379 \mathrm{~A}$, Cores $24-25 ; 380$, Cores $17-18,22,32-33$, common.

Holotype: Plate 17, Figure 11; from Leg 42B, Sample 379A-24-6, $21-23 \mathrm{~cm}$, Black Sea.

Paratype: Plate 17, Figure 12.

\section{Stephanodiscus hantzschii Grunow}

(Plate 15, Figure 11; Plate 21, Figures 7, 8)

Description: Hustedt (1930), p. 370, fig. 194

DSDP Leg 42B occurrences: Found common in the Pleistocene and late Pliocene sections of Holes $380 \mathrm{~A}$ and 381.

Stephanodiscus marginatus Mukhina sp. nov.

(Plate 6, Figure 9; Plate 9, Figure 3)

Description: Valve uniformly convex, $15-47 \mu \mathrm{m}$ in diameter. It has a broad margin distinctly separated from the valve. The margin surface is covered with ribs, 7 ribs in $10 \mu \mathrm{m}$. The margin zone has coarse rare spikes.

Between ribs there are fascicles of small pores which continue for a short distance over the peripheral zone of the valve. The middle part of the valve is thickly covered with areolae in random arrangement, varying in size. Isolated pores occur among the areolae.

DSDP Leg 42B occurrences: Fresh-water species; late Pliocene. Hole 380A, Core 38-49: 381, Cores 22-29, common.

Holotype: Plate 6, Figure 9; from Leg 42B, Sample 381-28-2, 78-80 $\mathrm{cm}$, Black Sea.

Paratype: Plate 9, Figure 3.

Stephanodiscus pontica Jousé sp. nov.

(Plate 6, Figures 11-13; Plate 7, Figures 1-12; Plate 8, Figures 4-12)
Description: Valves broadly triangular, rounded, at times crescent, the dorsal side convex, the ventral side concave. The center of the valve is always offset toward the dorsal side. Rounded valves $5-20 \mu \mathrm{m}$ in diameter, the long axis of triangular forms 5-20 $\mu \mathrm{m}$ long, 10-15 $\mu \mathrm{m}$ high.

The rows of areolae are arranged in fan-shaped divergent fascicles; 2 to 3 rows of areolae in each fascicle near the edge of one row toward the center. There are minute spikes at the base of each fascicle.

Remarks: The species has a high degree of polymorphism. Some rounded forms are very akin to Stephanodiscus kanitzii.

DSDP Leg 42B occurrences: Brackish-water species (up to $5 \%$ ); late Pliocene. Holes 380A, Cores 41-45; 381, Cores 26-28, abundant.

Holotype: Plate 7, Figure 7; from Leg 42B, Sample 381-27-2, 50-68 $\mathrm{cm}$, Black Sea.

Paratype: Plate 6, Figures 11-13; Plate 7, Figures 1-6, 8-12; Plate 8 , Figures $4-12$

\section{Stephanodiscus prohantzschii Jousé sp. nov.}

(Plate 4, Figures 10-11)

Description: Valve flat, $10-32 \mu \mathrm{m}$ in diameter. Valve fold $5 \mu \mathrm{m}$ wide. Small pores arranged in more or less regular rows, 15-16 rows in $10 \mu \mathrm{m}$, the fascicles indistinct, narrow ( 2 rows of pores each). The pores are somewhat rarified at the center. One pore is larger and convex, of the nodule type. The margin has dense spikes interwoven to form a peculiar fringe, 8 spikes in $10 \mu \mathrm{m}$.

The valve fold is finely striated, at times with minute costae in descussate order. Colonies are common, in which cells are tightly connected with one another.

Remarks: The species seems to form on evolutionary series with Stephanodiscus hantzschii. There is a definite similarity in valve structure between the two species.

DSDP Leg 42B occurrences: Brackish-water species; late Pliocene. Sites 380 A, Cores $46-54$; 381, Cores $28-34$, common.

Holotype: Plate 4, Figure 10

\section{Thalassiosira makarovae Mukhina sp. nov.} (Plate 6, Figure 14)

Description: Valve flat, $45-60 \mu \mathrm{m}$ in diameter. The structure is finely aerolate, $14-16$ areolae in $10 \mu \mathrm{m}$. The areolae are arranged in linear and tangential rows. Small spikes (processes) are scattered all over the valve. One row of spines, 8 to 9 in $10 \mu \mathrm{m}$, at the margin. The valve is yellowish.

Remarks: The species is named in honor of 1. V. Makarova, an algologist.

DSDP Leg 42B occurrences: Salt-water fresh-water species; late Pliocene. Hole 380A, Cores 43, 46; 381, Cores 29-30, rare.

Holotype: Plate 6, Figure 14, from Leg 42B, Sample 380A-43-2m $79-87 \mathrm{~cm}$.

Thalassiosira aff. oestrupii (Ostf.) Proshkina-Lavrenko

(Plate 19, Figures 1-5; Plate 22, Figures 3-6)

Description: Hasle (1960), p. 8, pl. 1, fig. 5-7.

DSDP Leg 42B occurrences: Found in varying abundance in the Pleistocene sections of Holes 379A, 380, and in the Holocene sections of Core 1857.

Thalassiosira subsalina Proshkina-Lavrenko

(Plate 18, Figure 9; Plate 21, Figures 9-12)

Description: Proshkina-Lavrenko (1955), p. 64, pl. 11, fig. 4.

DSDP Leg 42B occurrences: Found in varying abundance in the Pleistocene sections of Holes $379 \mathrm{~A}$ and 380 .

\section{ACKNOWLEDGMENTS}

The authors are very grateful to Professors Dr. D. Ross and Dr. Y. Neprochnov for an opportunity to study Diatoms in the cores from the Black Sea (Leg 42B). The authors thank Professors P.L. Bezrukov and A.P. Lisitsin who have read our manuscript and made valuable critical remarks. We are also very grateful for the help of our colleague N. Spasskaya who prepared most of the samples and slides. Thanks are also due to Mrs. A.Y. Shevchenko for her help with SEM (scanning electron microscope). 


\section{REFERENCES}

Arslavnov, X.A., Izmailov, J.A., et al., 1976. The absolute age of Karangat Terrass from West Caucasus and Kerchensk bay: Dokl. AN USSR, v. 226, p. 159-162.

Arkhangelskiy, A.D. and Strakhov, N.M. 1938. The geological structure and history of development of the Black Sea: Izd. AN USSR, p. 1-201.

The Diatom Algae of the USSR. Fossil and Modern. 1974. Izd. Nauka, v. 1, p. 1-400.

Ehrlich, A. 1967. Etude de quelques gisements diatomiferes villafranchieus de bassin du Puy. Bulletin de L'Association francaise pour l'etude du Quaternaire: Paris, p. 293-304. 1973. Quaternary Diatoms of the Hula Basin (Northern Israel): Geol. Surv. Israel, Bull 58, p. 1-39.

Federov, P.V., 1963. The stratigraphy of the Quaternary sediments of the Crimea-Caucasus coast area and some questions of the geological history of the Black Sea: GIN AN USSR, Trudy, issue 88, Moscow, p. 1-159.

Gasse, P., 1972. Etude des Diatomees de Gisement Quaternaire de Saint-Saturnin (Puy-de Dome): Int. Rev. Ges. Hydrobiol., v. 57, p. 321-351.

Hajos, M. and Gyula, R., 1969. Diatomas retegek a Bukkalji Alsopannonbol: Magyar allami foldtani intezet, p. 271297.

Hajos, M. and Holzer H., 1972. Keiselgurvorkommen im Tertiarbecken von Aflenz (Steiermark): Sonderdruck ous Mitteilungen der Geologischen Gessellschaff in Wien, v. 63 , p. $149-159$.

Hasle, G.R., 1960. Phytoplankton and Ciliate species from the tropical Pacific: Oslo, p. 1-50.

Heribaud. J., 1903. Les diatomees fossiles d'Auvergné. Mem. 2, p. $1-166$.

Hustedt, F., 1930. Die Keiselalgen Deutschlands, Osterreichs und der Schweiz unter Berucksichtigung der ubrigen
Lander Europas sowie der angrenzenden Meeresgebiete: Kryptogamen Flora, von Deutsche, Osterr, u.d. Schweiz. Teil. 1, 7, 1. Leipzig. p. 1-920.

Jousé, A.P., 1949. Diatomic analysis: books 1-3. 1952. On the history of the diatom flora of Lake Khanka. Trudy Inst. Geogr. AN USSR, issue 51.

Markov, K.K., Lazukov, G.I. and Nikolaev, V.A. 1965. The Quaternary (Glacial Period-anthropogenic period): v. 11, the territory of the USSR, p. 218-242.

Proshkina-Lavrenko, A.I., 1955. The diatom algae of the plankton of the Black Sea: Izd. AN USSR, p. 1-222. 1963. The diatom algae of the benthos of the Black Sea: Mowcow-Leningrad, p. 1-234.

Rehakova, Z. 1965. Fossile Diatomeen der Sudbohemischen Beckenablagerungen: Praha, p. 1-96. 1969. Changements qualitatifs des associations de Diatomees dans les sediments tertiaires et quaternaires de Tchecoslavaquie: VIII-e Congress INQUA, Paris, p. 276302.

1975. Marine Diatoms in Helvetian sediments of the Central Paratethys: Nova Hedwig. v. 53, p. 293-303.

Reichert, H. 1899-1900. Uber fossile Diatomeen aus Nordbohemen; Ber. Naturf. Ges., p. 27-35.

Schmidt, A., 1972. Atlas der Diatomaceen-Kunde: v. 1-4, Leipzig.

Servant-Vildary, S., 1973. Le Plio-Quarternaire ancien du Tchad: evolution des associations de Diatomees, stratigraphie, paleoecologie: Cah. Orstrom, ser. Geol., v. 5 , p. $169-216$.

Shimkus, K.M., Mukhina, V.V., and Trimonis, E.S., 1973. The role of diatoms in the late Quaternary sedimentation of the Black Sea: Okeanologiya, v. 13, issue 6. 
PLATE 1

Figures 1-3 Actinoptychus undulatus (Bail.) Ralfs. Sample 380A-56-4, 77-79 cm.

1. $\times 800$.

2. $\times 1100$.

Figure 4. Actinocyclus ehrenbergii Ralfs.

Sample 380 A $-56-4,77-79 \mathrm{~cm} . \times 1000$.

Figure 5. Paralia sulcata (Ehr.) Kutz.

Sample 380 A-56-4, $77-79 \mathrm{~cm} . \times 3500$

Figure 6 Diploneis elliptica (Kutz.) Cleve.

Sample $381-35-5,105-120 \mathrm{~cm} . \times 2000$ (valve in interior view).

Figure $7 \quad$ Cocconeis scutellum Ehr.

Sample 380 A-56-4, $77-79 \mathrm{~cm} . \times 1100$.

Figure $8 \quad$ Cocconeis placentula Ehr.

Sample 381-35-5, 57-59 cm. $\times 1000$.

Figure 9 Archaeomonas sp.

Sample $381-37$, CC. $\times 2000$.

Figure $10 \quad$ Amphora sp.

Sample 381-35-5, 57-59 cm. $\times 1100$.

Figure 11 Chaetoceros danicus Cleve.

Sample 381-35-5, 57-59 cm. $\times 1000$.

Figures 12-13 Rhizosolenia bezrukovii Jousé.

Sample 381-35-5, 57-59 cm. $\times 1000$.

Figure 14 Hermesinum adriaticum Zach.

Sample 381-35-5, 57-59 cm. $\times 1000$. 
PLATE 1
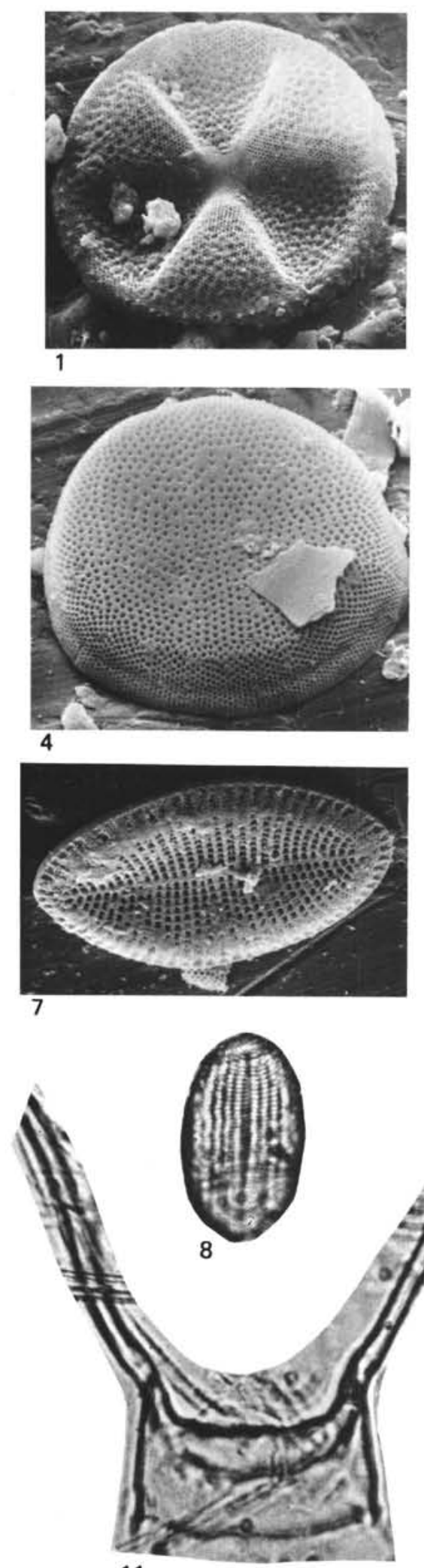

11
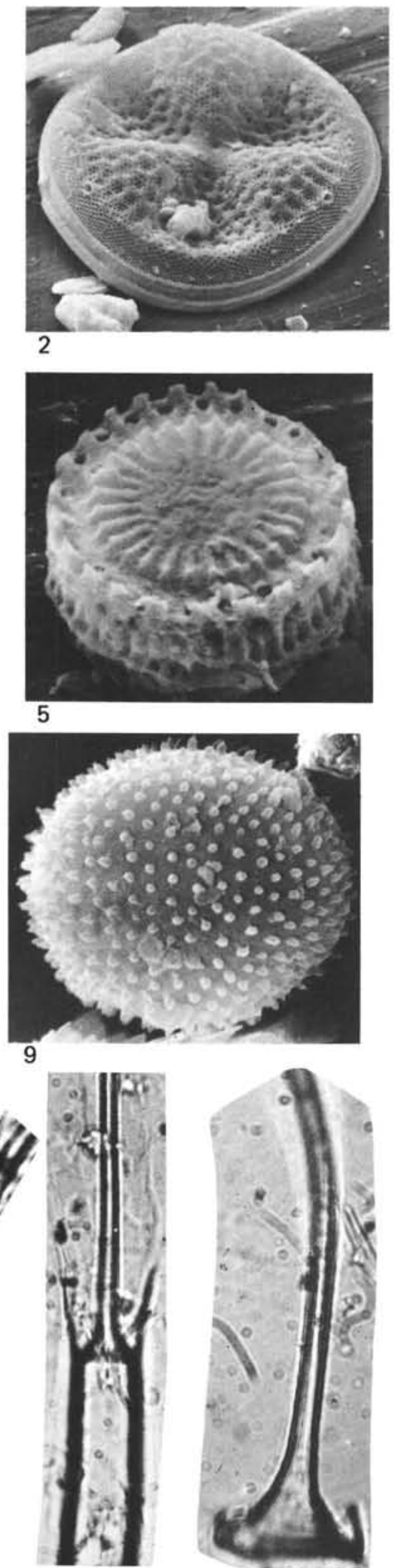

12

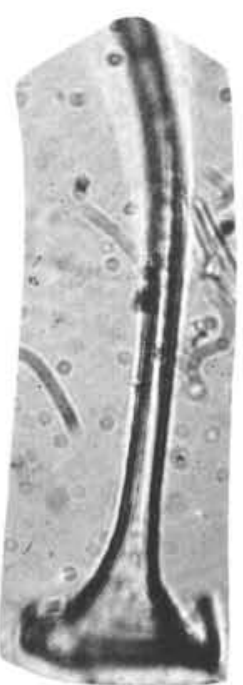

13

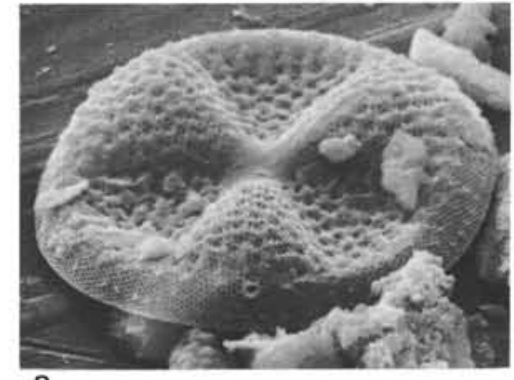

3
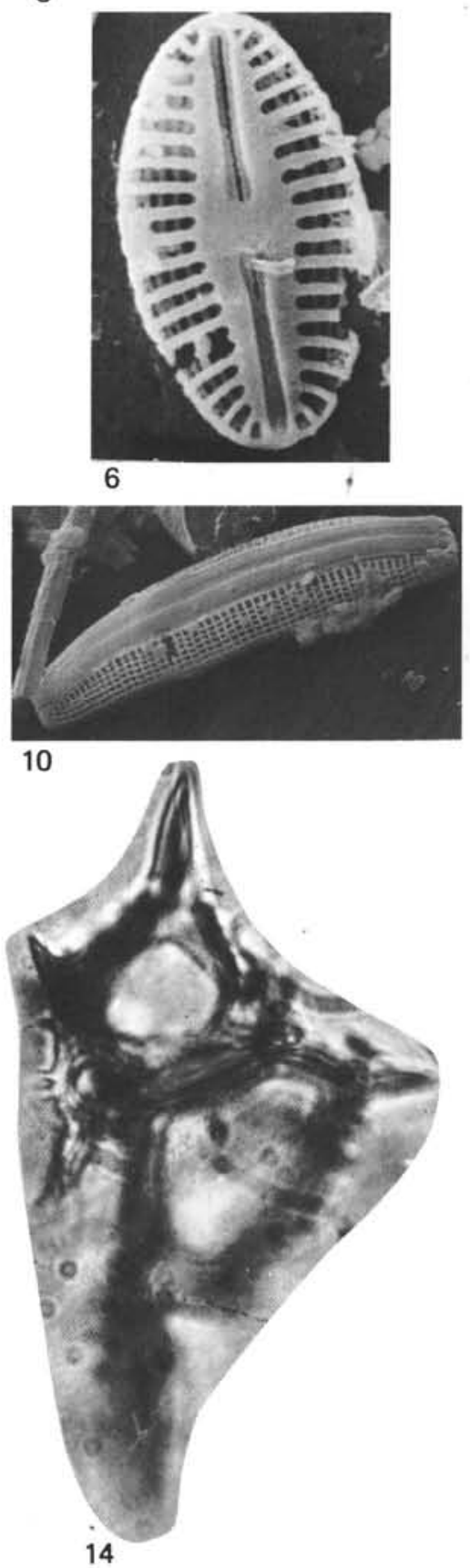


\section{PLATE 2}

Figures 1-4 Stephanodiscus carconensis Grun. Sample 381-35-5, 105-120 cm.

1. $\times 2000$.

2. $\times 2500$.

3. $\times 2000$.

4. $\times 1200$.

Figures 5,6 Thalassiosira aff. subsalina Pr.-Lavr.

Sample 381-35-5, 105-120 cm.

5. $\times 1500$.

6. $\times 1200$.

Figure 7 Actinocyclus ehrenbergii Ralfs.

Sample $381-35-5,105-120 \mathrm{~cm} . \times 2000$.

Figures 8-14 Rhaphoneis maeotica (Milov.)Sheshuk and Gleser Sample 381-35-5, 105-120 cm.

8. $\times 700$.

9. $\times 1000$.

10. $\times 1500$.

11. $\times 1500$

12. $\times 1500$.

13. $\times 2000$.

14. Sample 380 A-56-4, 77-79 cm. $\times 1100$.

Figure 15 Stephanodiscus sp.

Sample $381-35-5,105-120 \mathrm{~cm} . \times 2500$.

\section{PLATE 3}

Figures 1-4 Actinocyclus ehrengergii Ralfs.

1, 2. Sample 381-35-1, 110-120 cm.

1. $\times 800$.

2. $\times 1000$.

3. Sample $380 \mathrm{~A}-56-4,77-79 \mathrm{~cm} . \times 1100$.

4. Sample 381-37, CC. $\times 1000$.

Figures 5-11 Cyclotella praekutzingiana Mukhina.

5, 7-10. Sample 381-35-5, 105-120 cm.

5. $\times 3000$.

7. $\times 2500$.

8. $\times 4000$.

9. $\times 1500$.

10. $\times 3000$.

6. Sample $381-35-1,110-120 \mathrm{~cm} \times 3500$.

11. Sample $381-35-5,55-57 \mathrm{~cm} . \times 1000$.

Figures 12, 13 Stephanodiscus carconensis Grun. Sample 381-35-5, 105-120 cm.

12. $\times 2500$.

13. $\times 1500$.

(see p. 920) 


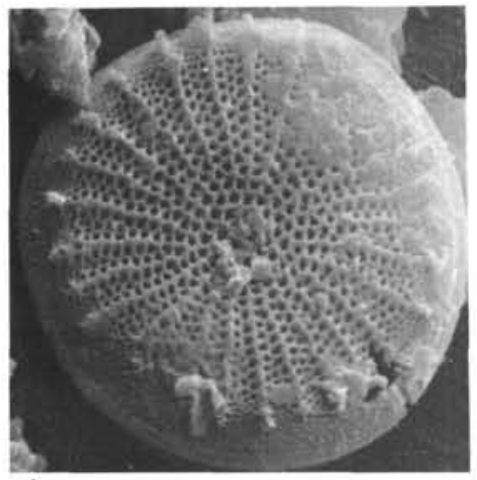

1
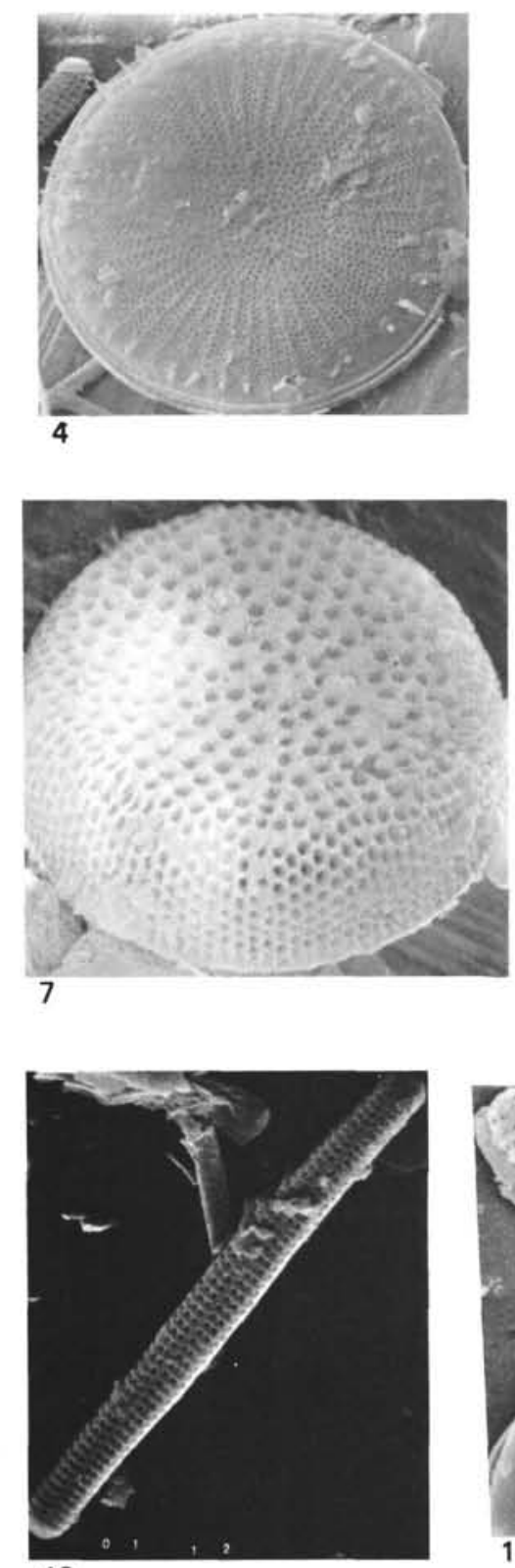

12

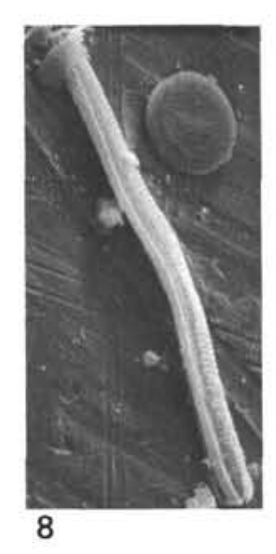

PLATE 2
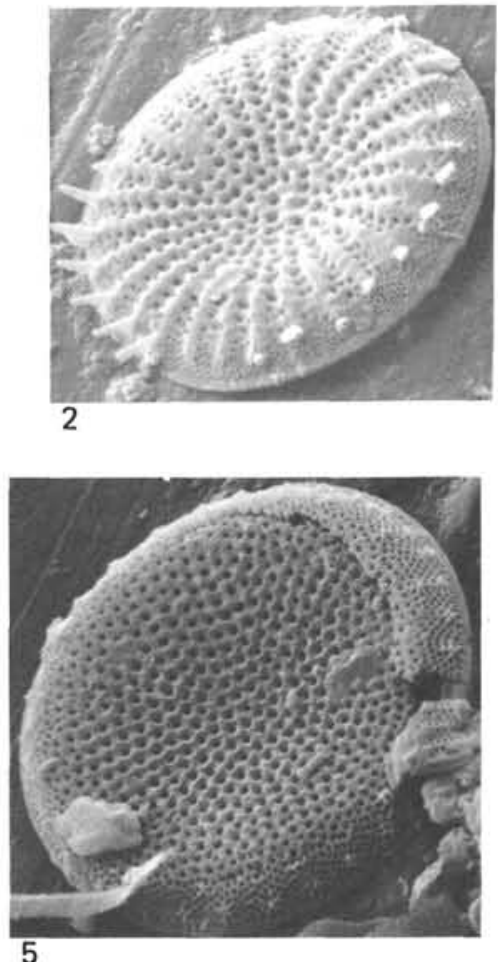

5

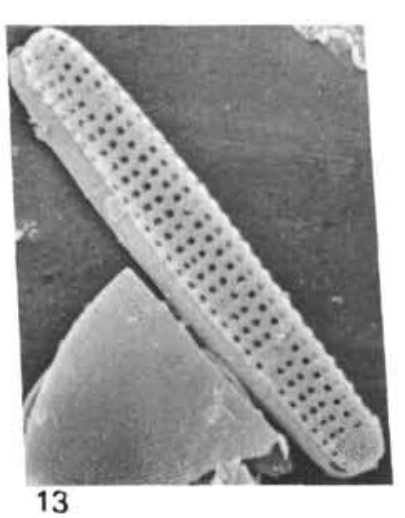

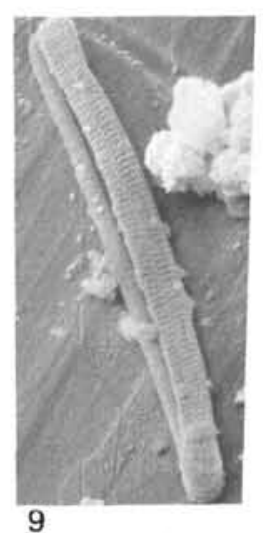

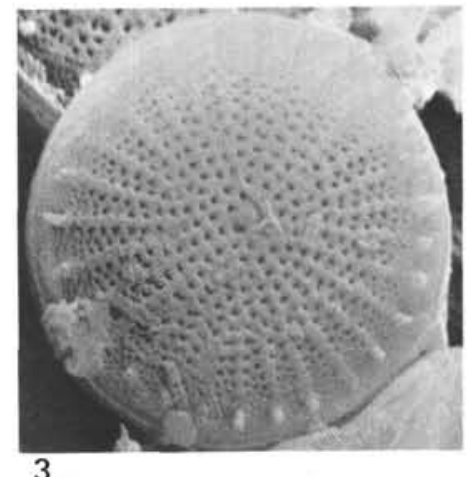

3
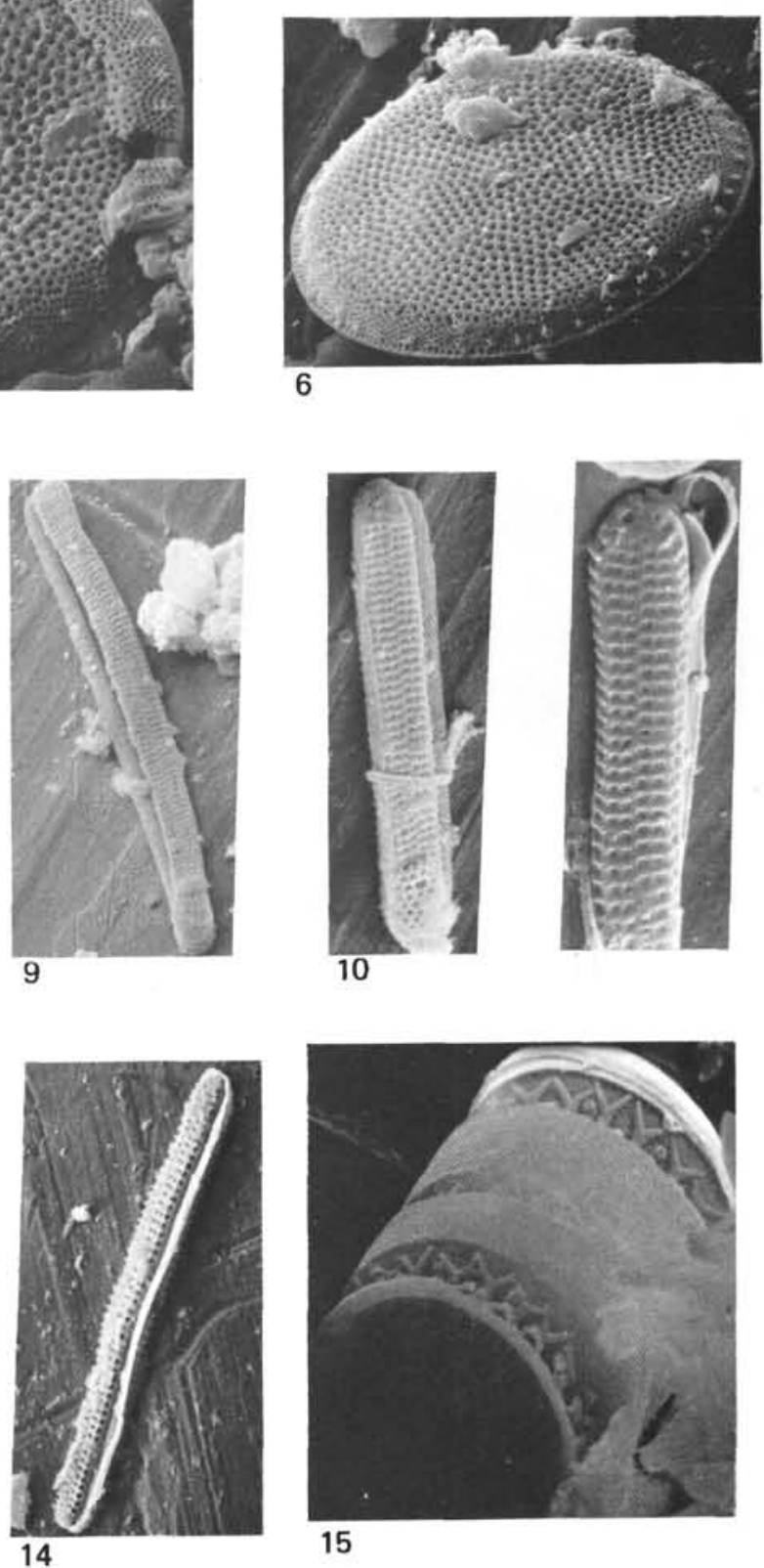
PLATE 3

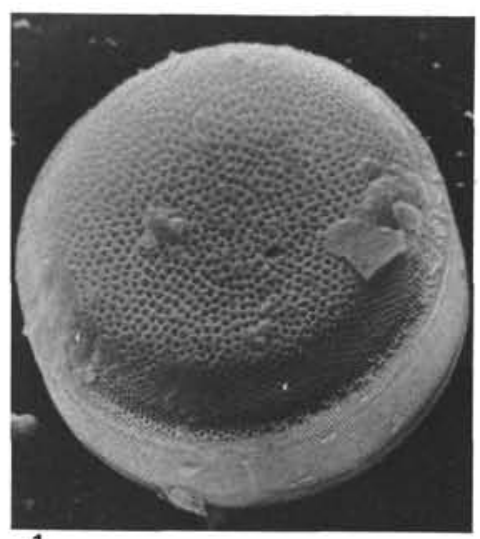

1
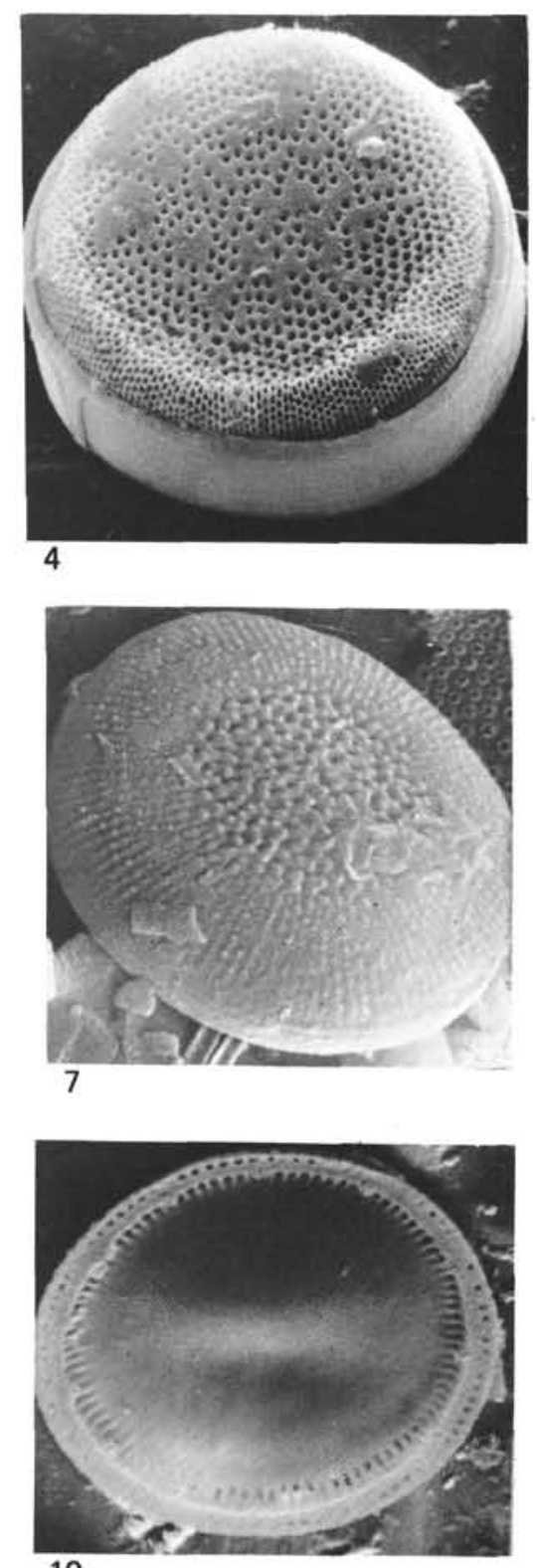

10
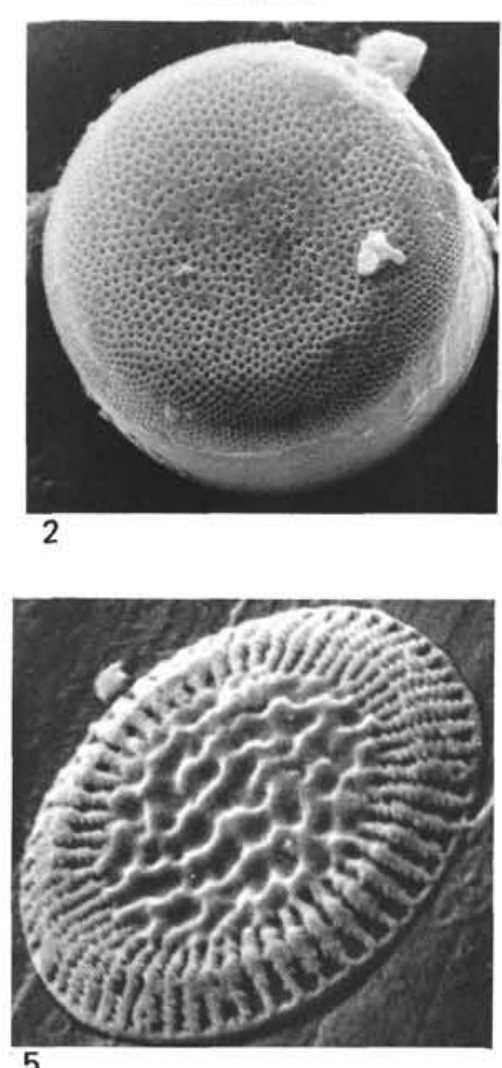

5

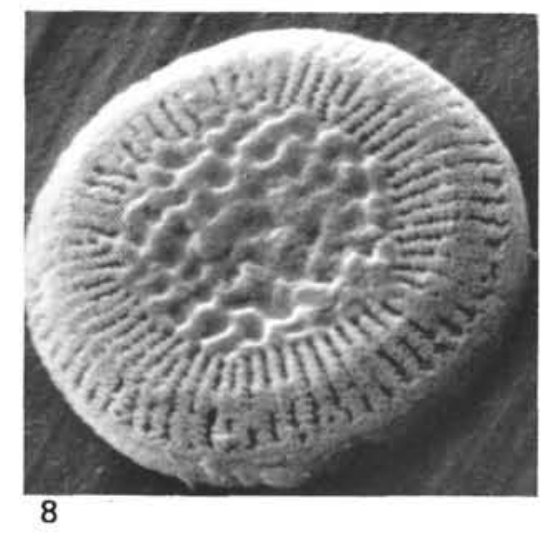

8

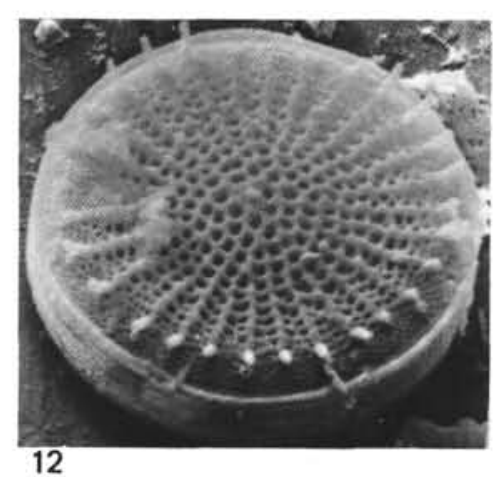

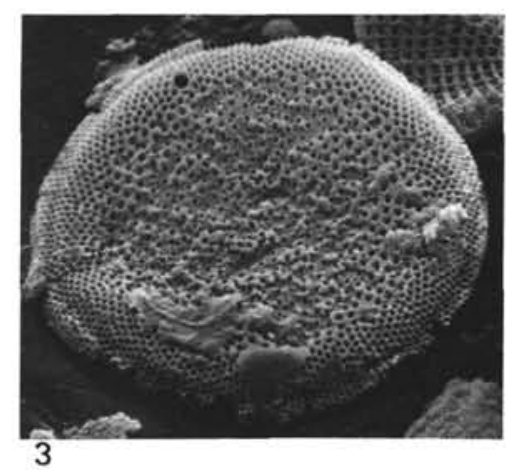

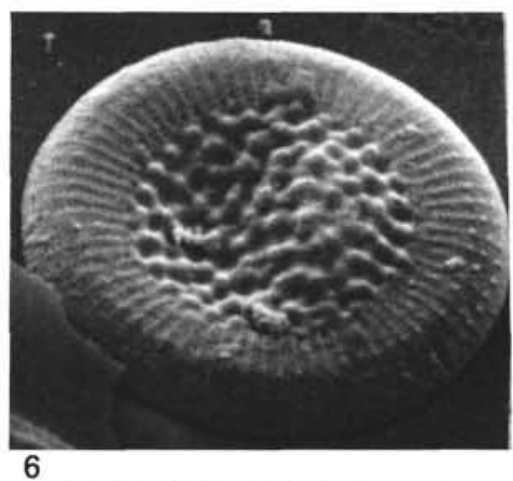

6

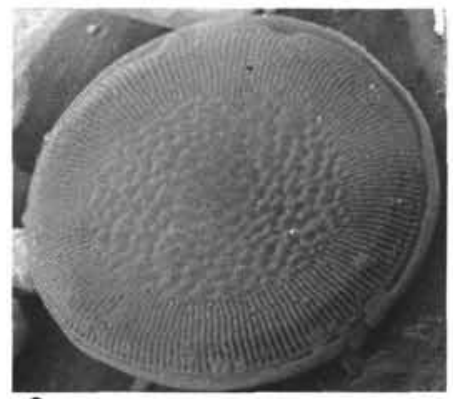

9

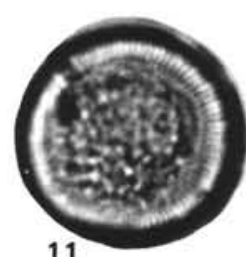

11

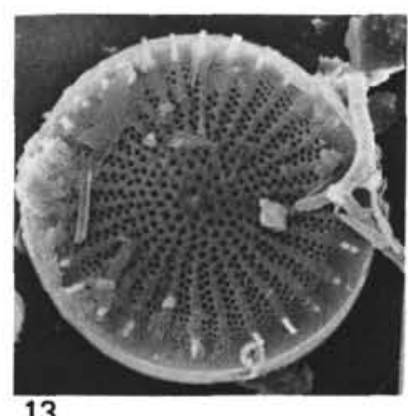

13 


\section{PLATE 4}

Figures 1-4 Stephanodiscus carconensis Grun.

1. Sample $380 \mathrm{~A}-54-1,66-78 \mathrm{~cm} . \times 1100$

2, 3. Sample $380 \mathrm{~A}-52-2,0-12 \mathrm{~cm}$.

2. $\times 1300$

3. $\times 1100$.

4. Sample $381-30-3,15-21 \mathrm{~cm} . \times 800$.

Figure $5 \quad$ Stephanodiscus niagarae Ehr.

Sample 380A-52-2, 0-12 cm. $\times 900$.

Figure $6 \quad$ Actinocyclus ehrenbergii Ralfs.

Sample $380 \mathrm{~A}-52-2,0-12 \mathrm{~cm} . \times 1000$.

Figures 7-9 Coscinodiscus stockesiansus (Grev.) Grun.

Sample 380 A-52-2, 0-12 cm.

7. $\times 700$.

8. $\times 600$.

9. $\times 1000$.

Figures 10,11 Stephanodiscus prohantzschii Jousé.

10. Sample $380 \mathrm{~A}-52-2,0-12 \mathrm{~cm} . \times 1000$.

11. Sample $381-30-3,15-21 \mathrm{~cm} . \times 4000$.

Figure 12 Cyclotella proshkinae Jouse and Mukhina. Sample $380 \mathrm{~A}-54-1,66-78 \mathrm{~cm} . \times 2500$.

(see p. 922)

\section{PLATE 5}

Figures 1-2, Melosira papilio Mukhina.

11-14 1, 2. Sample 381-32-1, 31-34 cm.

1. $\times 3500$.

2. $\times 2500$.

11- 14. Sample $381-31-2,110-115 \mathrm{~cm}$.

11- $12 . \times 2000$.

13. $\times 1500$.

14. $\times 3000$.

Figures 3-9 Melosira praegranulata Jouse.

3-4, 6-8. Sample 381-32-1, 31-34 cm.

$3,8 . \times 1500$.

4. $\times 1300$.

6. $\times 2000$.

7. $\times 8600$ (detail).

5. Sample 381-30-3, 15-21 cm. $\times 700$.

9. Sample 380A-39-3, $99-101 \mathrm{~cm} . \times 1500$.

Figure $10 \quad$ Melosira praeislandica Jouse.

Sample 381-30-3, 15-21 cm. $\times 1500$.

Figures 15, 16 Stephanodiscus speciosus Mukhina.

15. Sample 381-31-2, 110-115 cm. $\times 1500$.

16. Sample $381-32-1,31-34 \mathrm{~cm} . \times 2500$.

(see p. 923) 


\section{PLATE 4}
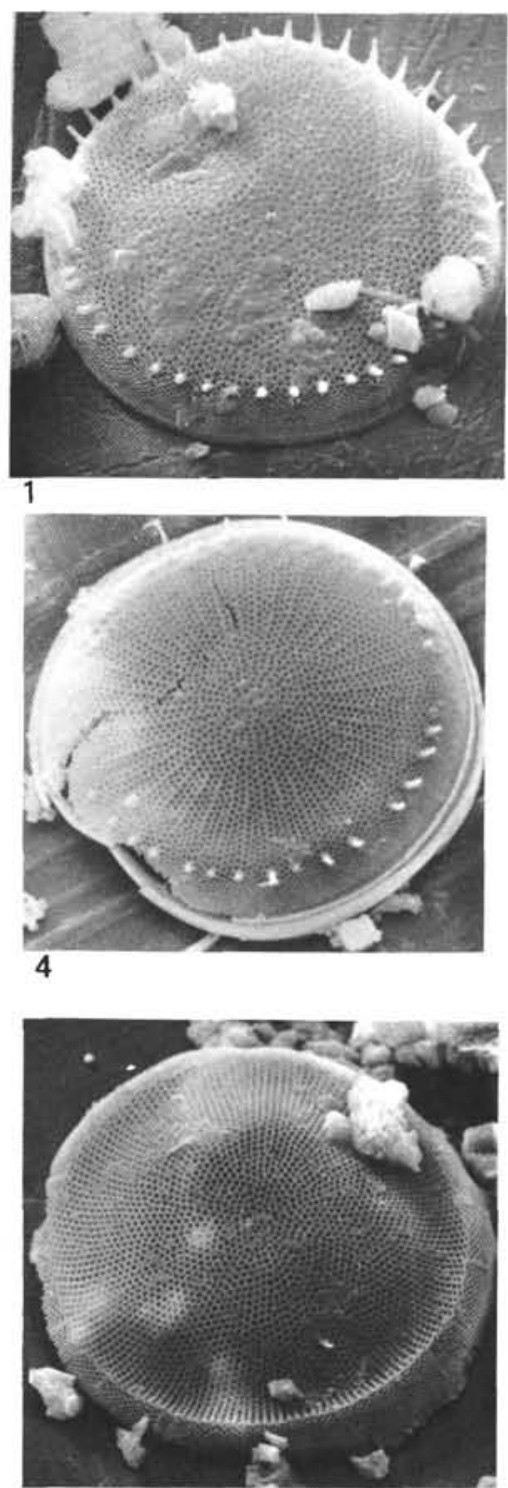

7

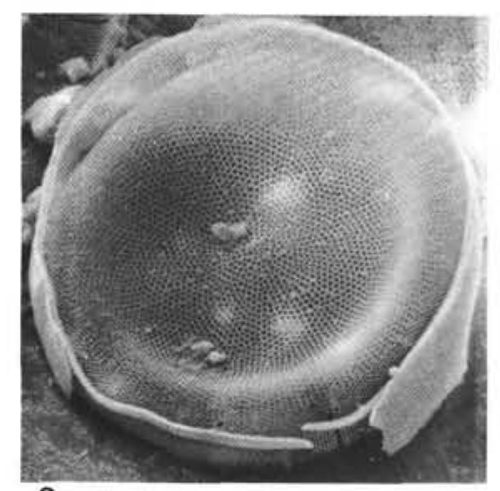

8
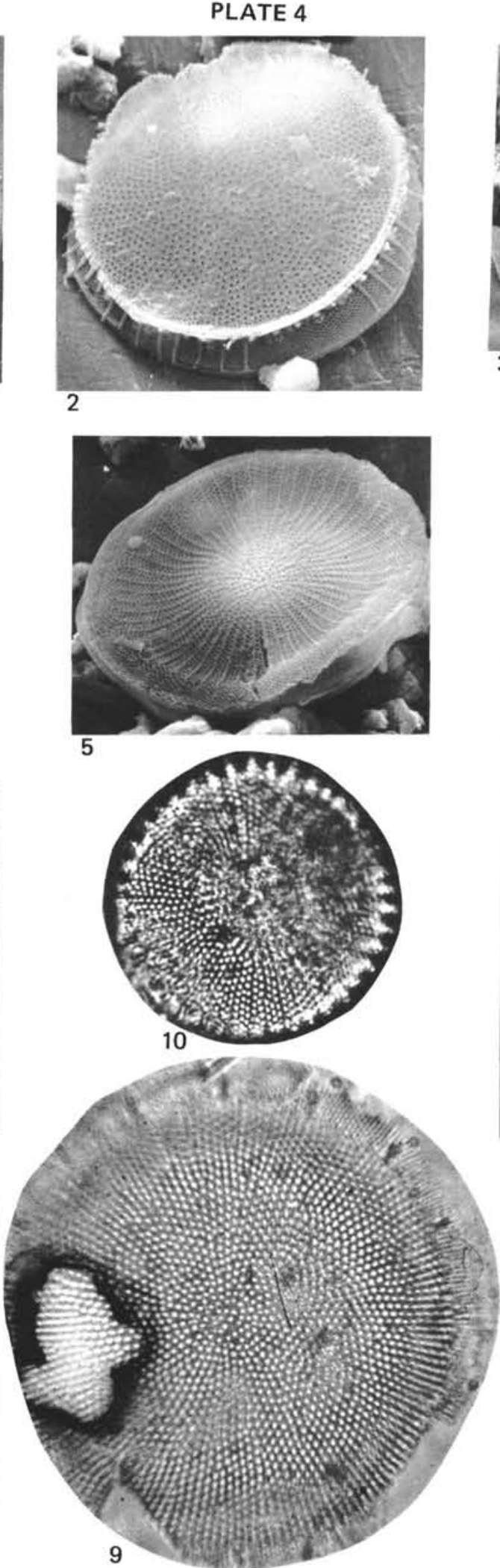

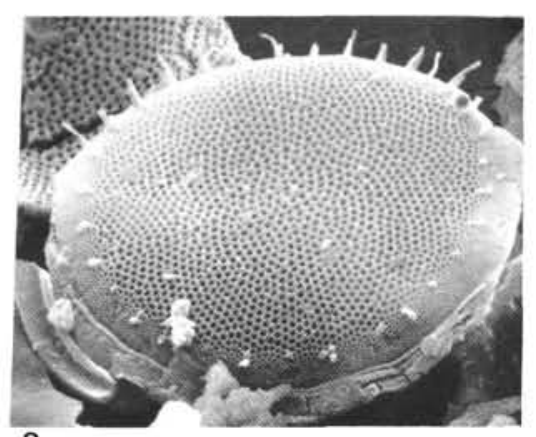

3
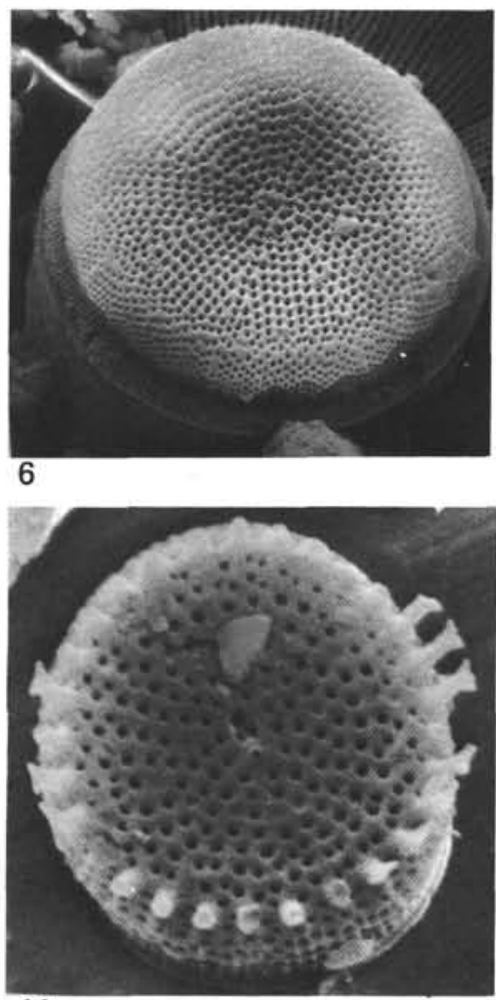

11

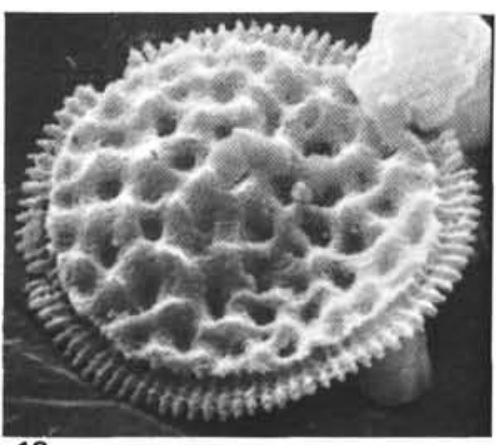

12 
PLATE 5

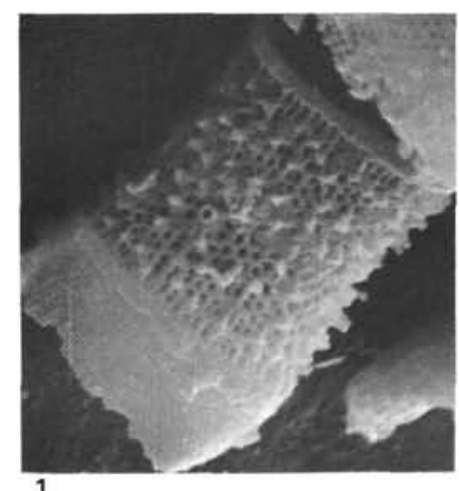

1

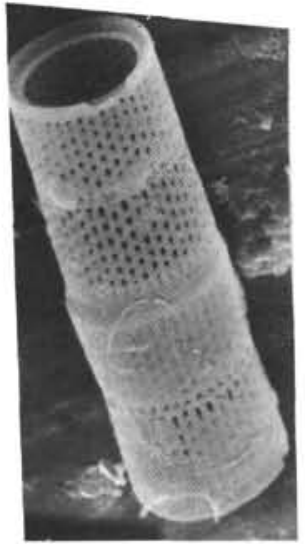

5

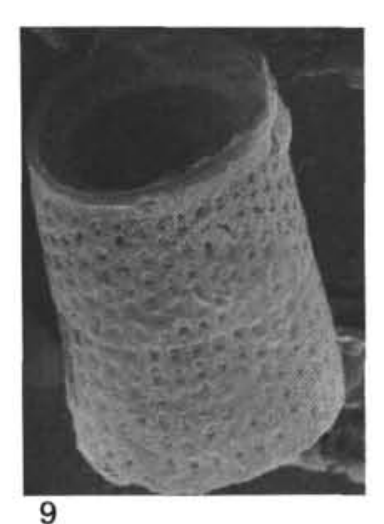

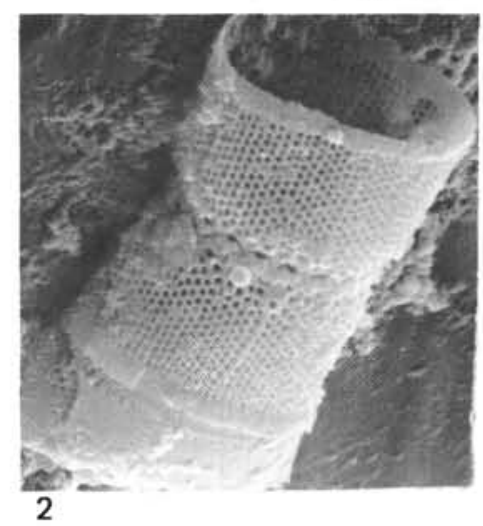
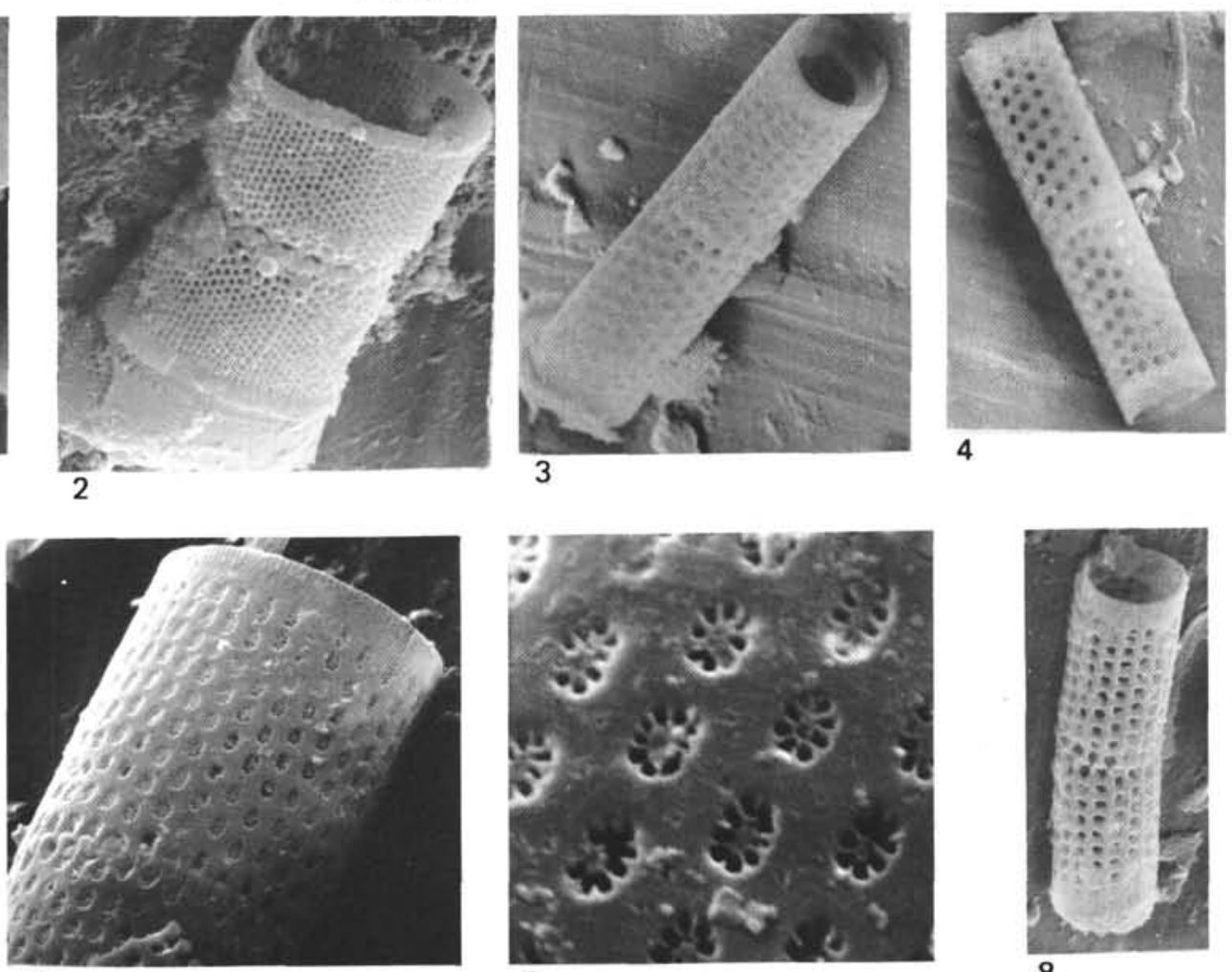

6
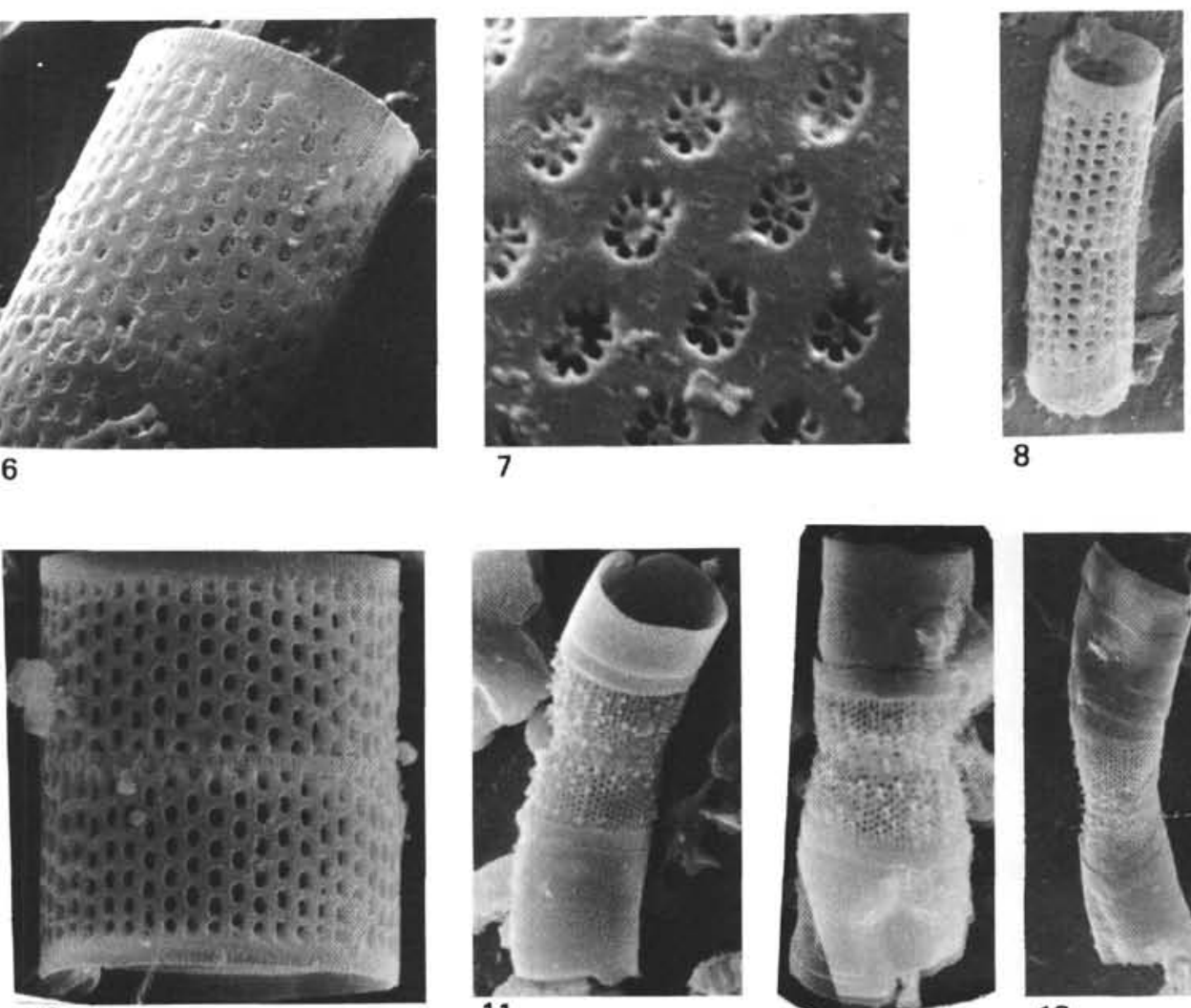

10
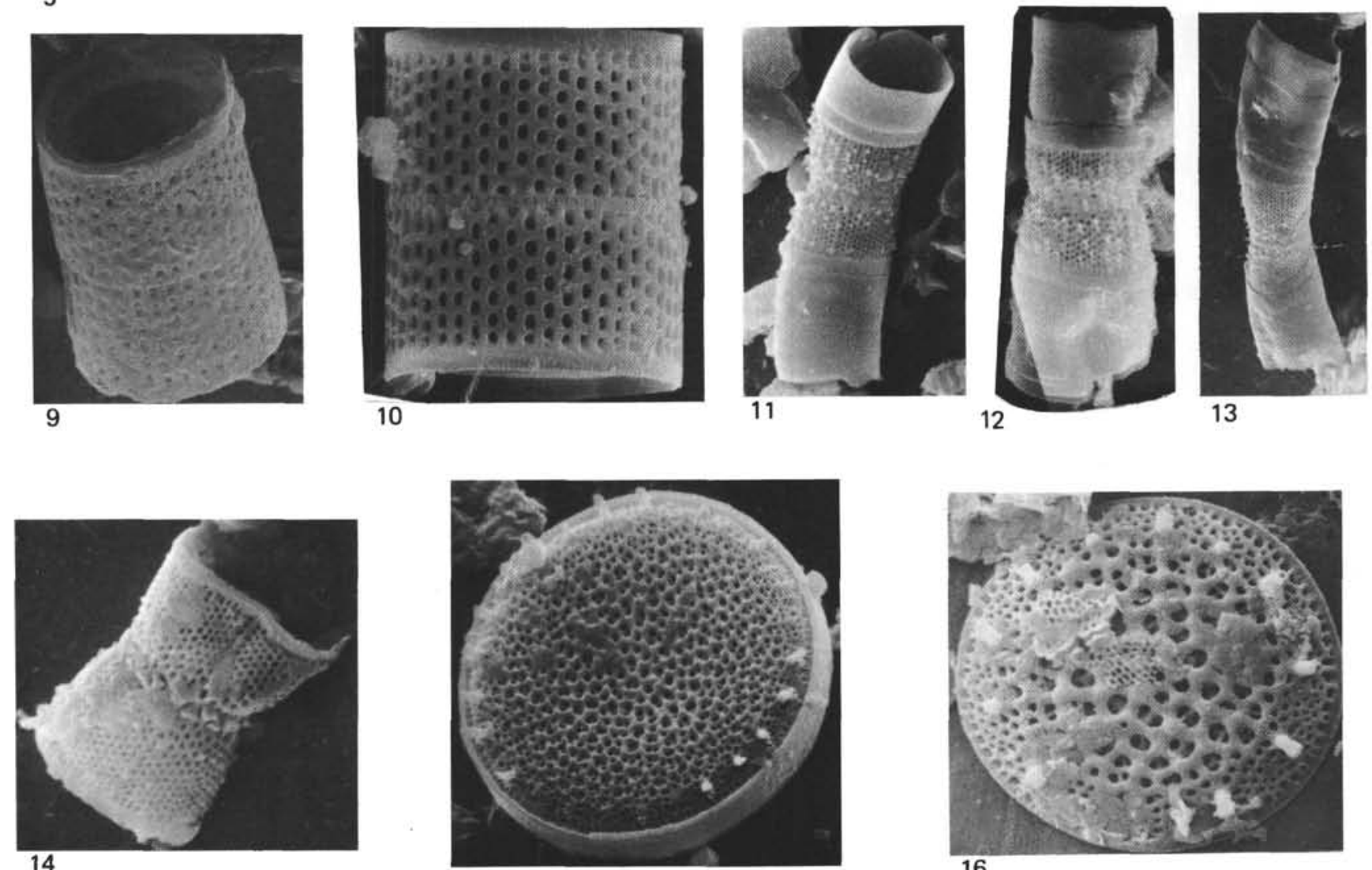

15

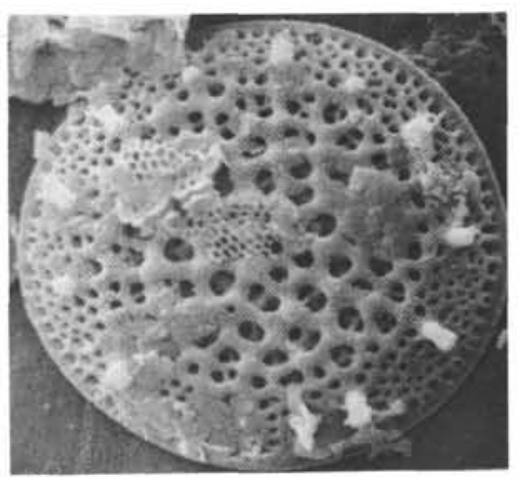

16 
PLATE 6

Figures 1-5 Stephanodiscus kanitzii Pant.

1- 2, 4. Sample 380A-43-2, $79-87 \mathrm{~cm}$.

$1,2 \times 2000$.

4. $\times 1500$.

3. Sample $381-28-2,78-80 \mathrm{~cm} . \times 1500$.

5. Sample $380 \mathrm{~A}-45-3,112-125 \mathrm{~cm} . \times 1000$.

Figures 6-8 Stephanodiscus matrensis Pant.

6. Sample $380 \mathrm{~A}-44-5,130-140 \mathrm{~cm} . \times 1000$.

7. Sample $381-28-2,78-80 \mathrm{~cm} . \times 2000$.

8. Sample 381-31-2, 110-115 cm. $\times 1500$.

Figure 9 Stephanodiscus marginatus Mukhina. Sample 381-28-2, 78-80 cm. $\times 1500$.

Figure $10 \quad$ Coscinodiscus aff. gorbunovii Sheshuk. Sample 381-28-2, 78-80 cm $\times 1000$.

Figures 11-13 Stephanodiscus pontica Jouse.

11. Sample $380 \mathrm{~A}-44-5,130-140 \mathrm{~cm} . \times 1000$.

12, 13. Sample $380 \mathrm{~A}-41-6,108-122 \mathrm{~cm} . \times 1000$.

Figure $14 \quad$ Thalassiosira makarovae Mukhina.

Sample 380A-43-2, 79-87 cm. $\times 700$.

Figure $15 \quad$ Melosira bellicosa Herib.

Sample 380 A-44-4, $55-57 \mathrm{~cm} \times 1100$.

Figure $16 \quad$ Melosira hibschii Reich.

Sample 380 A-44-4, $55-57 \mathrm{~cm} . \times 1500$.

\section{PLATE 7}

Figures 1-12 Stephanodiscus pontica Jouse.

1- 10. Sample 381-27-2, 50-68 cm.

$1,2,5,6,8,10 . \times 2000$.

$3,4,7,9$. $\times 2000$.

11,12 . Sample $381-30-3,15-21 \mathrm{~cm} . \times 2000$.

(see p. 926) 


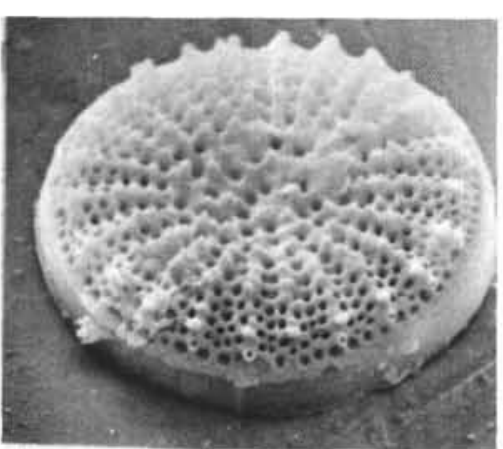

1
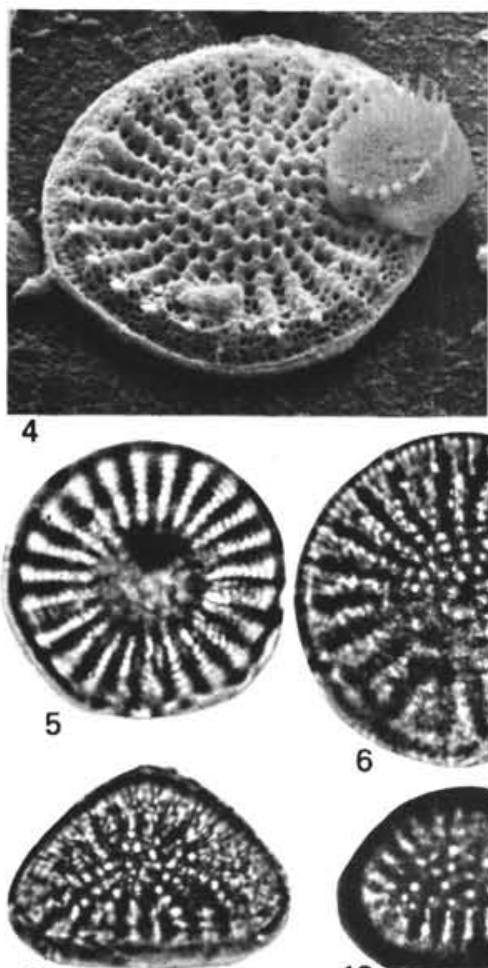

11

12
PLATE 6
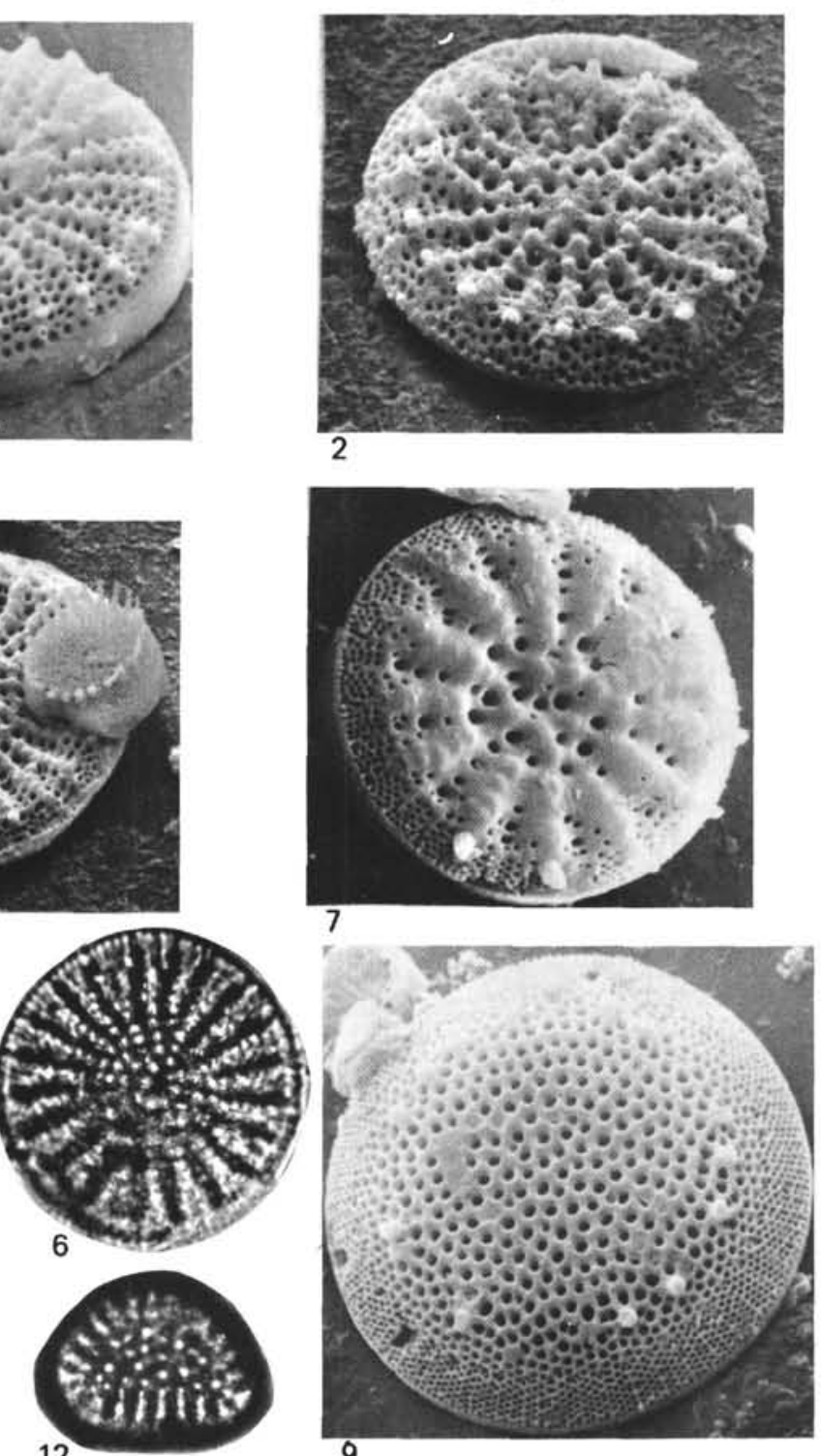

9

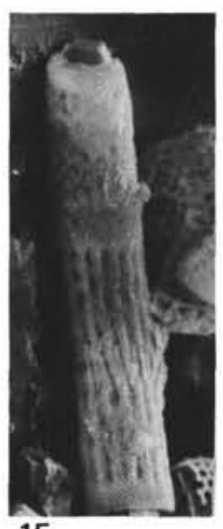

15
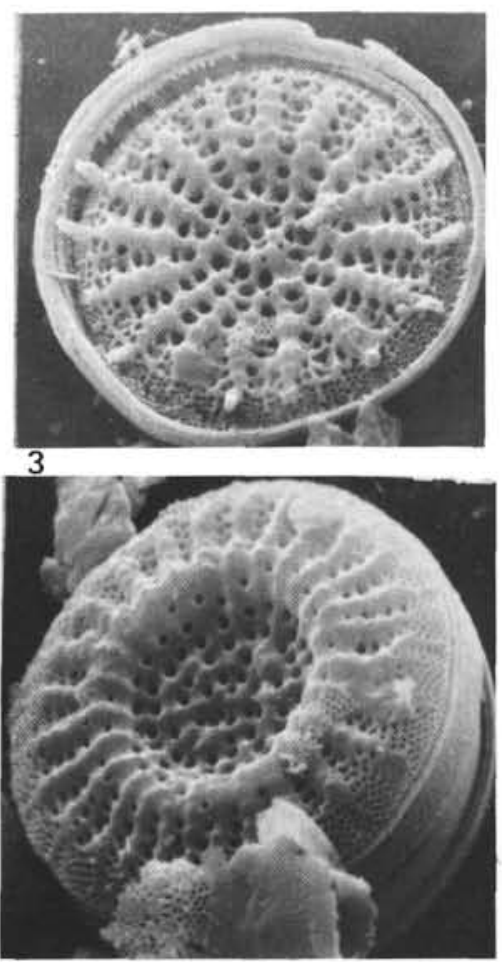

8
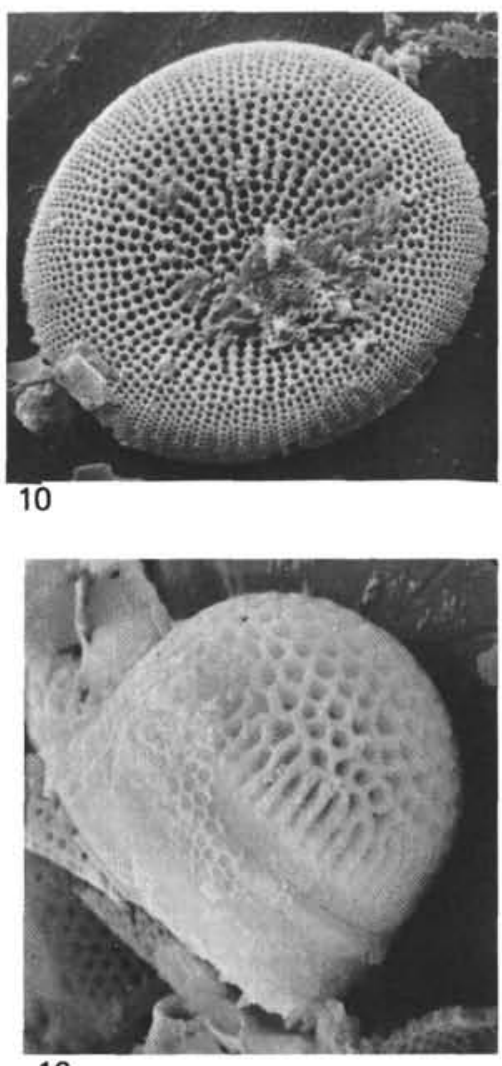
PLATE 7

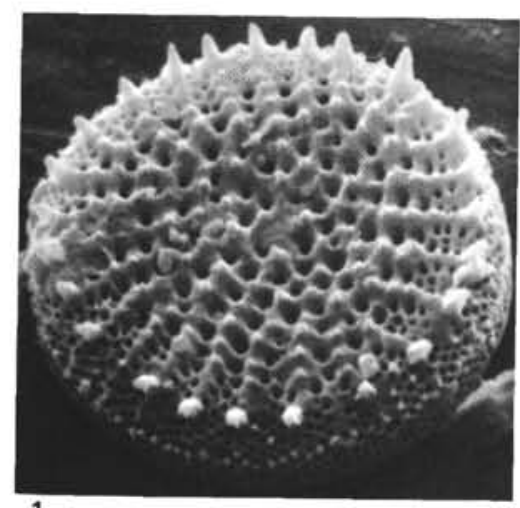

1
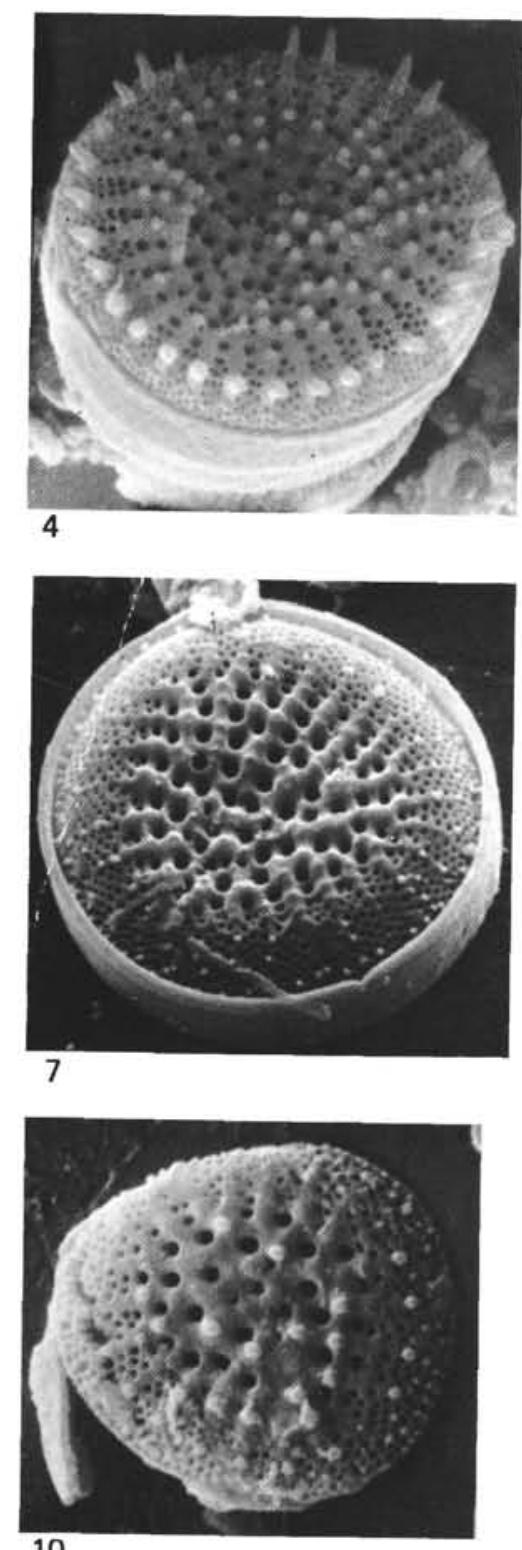

10
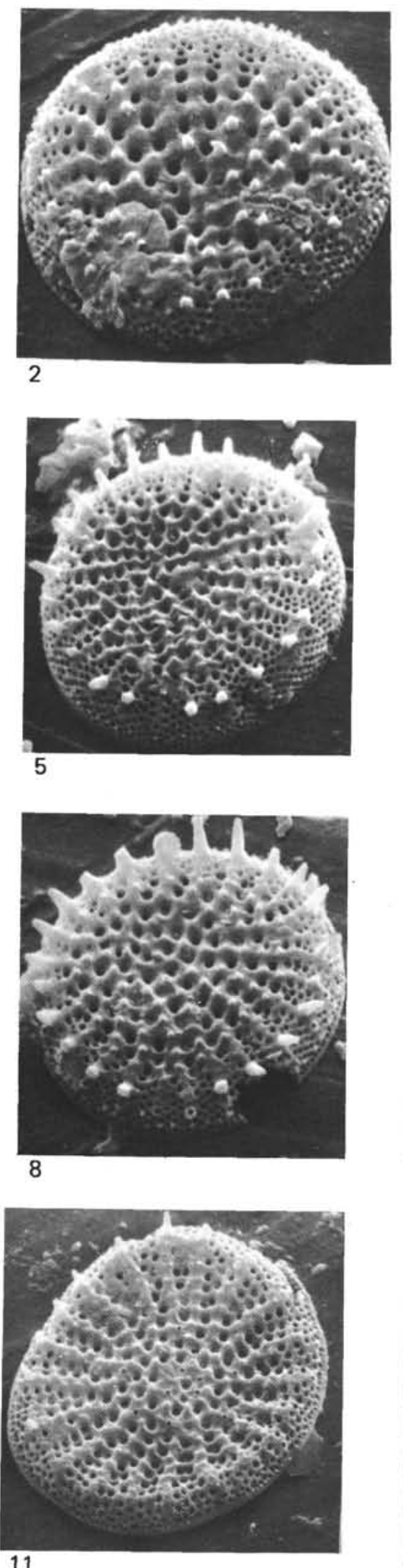

11
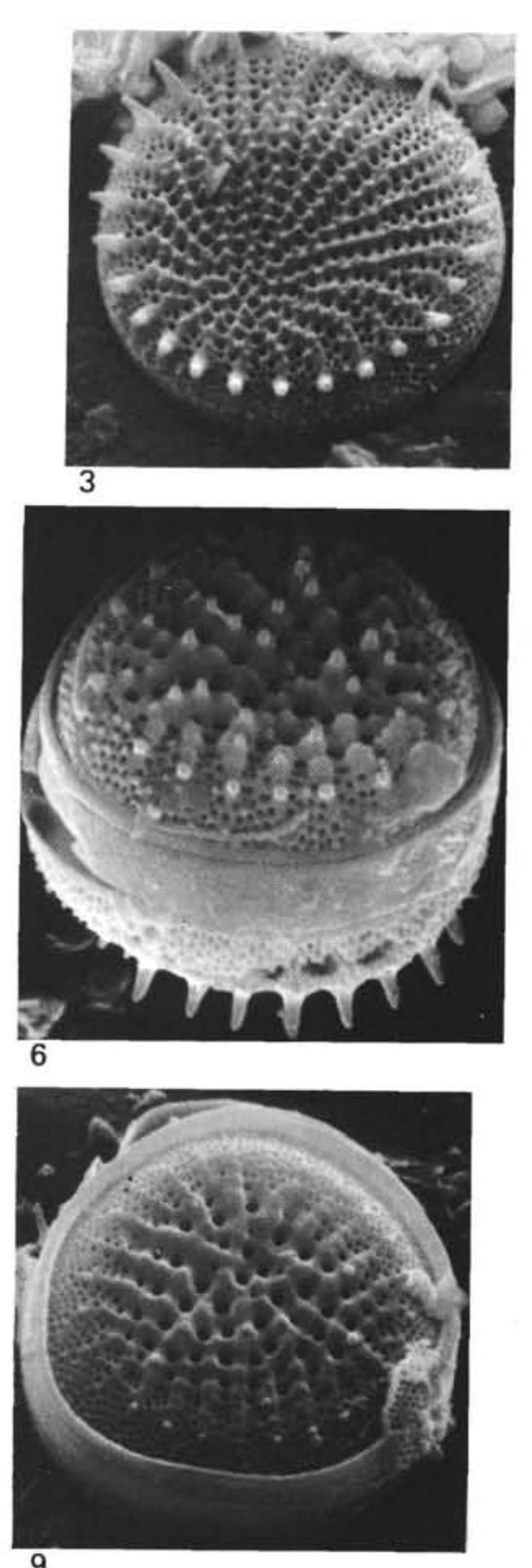

9

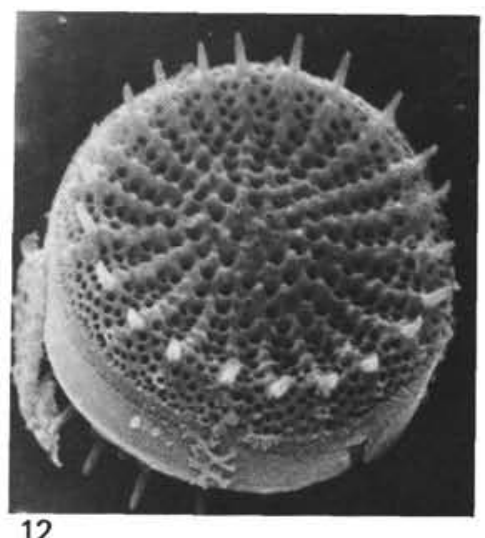




\section{PLATE 8}

Figure $1 \quad$ Cyclotella servant-vildary Mukhina

Sample $381-25-4,50-65 \mathrm{~cm} . \times 2000$.

Figure 2 Cyclotella servant-vildary var. elegans Mukhina. Sample $381-27-2,50-68 \mathrm{~cm} . \times 1300$ (valve in interior view).

Figure 3 Stephanodiscus dubious (Fricke) Hust.

Sample 381-27-2, 50-68 cm. $\times 2000$.

Figures 4-12 Stephanodiscus pontica Jousé.

4- $9,11,12$. Sample $381-27-2,50-68 \mathrm{~cm}$.

$4,7-9 . \times 2500$.

$5,11,12 . \times 2000$.

6. $\times 1500$.

10. Sample $381-30-3,15-21 \mathrm{~cm} . \times 3000$.

(see p. 928)

\section{PLATE 9}

Figures 1,2 Stephanodiscus dubius (Fricke) Hust. Sample 380A-38-3, 136-138 cm. $\times 1000$.

Figure 3 Stephanodiscus marginatus Mukhina. Sample 380 A-38-3, $136-138 \mathrm{~cm} . \times 1000$.

Figure $4 \quad$ Thalassiosira $\mathrm{sp}$.

Sample 380A-32-1, 6-9 cm. $\times 1000$.

Figures 5-7 Melosira elegans Mukhina.

5. Sample 380 A-39-3, $99-101 \mathrm{~cm} . \times 1000$.

6, 7. Sample $380 \mathrm{~A}-32-1,6-9 \mathrm{~cm} . \times 1000$.

Figures 8, 9 Melosira praegranulata Jouse.

Sample 380A-39-3, 99-101 cm. $\times 1000$.

Figures 10-16 Melosira praegranulata f. curvata Jouse.

10 , 11. Sample $380 \mathrm{~A}-38-5,99-101 \mathrm{~cm} . \times 1000$.

12- 16. Sample $380 \mathrm{~A}-44-4,55-57 \mathrm{~cm}$.

$12,13 . \times 1500$.

14. $\times 800$.

15. $\times 700$.

16. $\times 1200$.

(see p. 929) 
PLATE 8
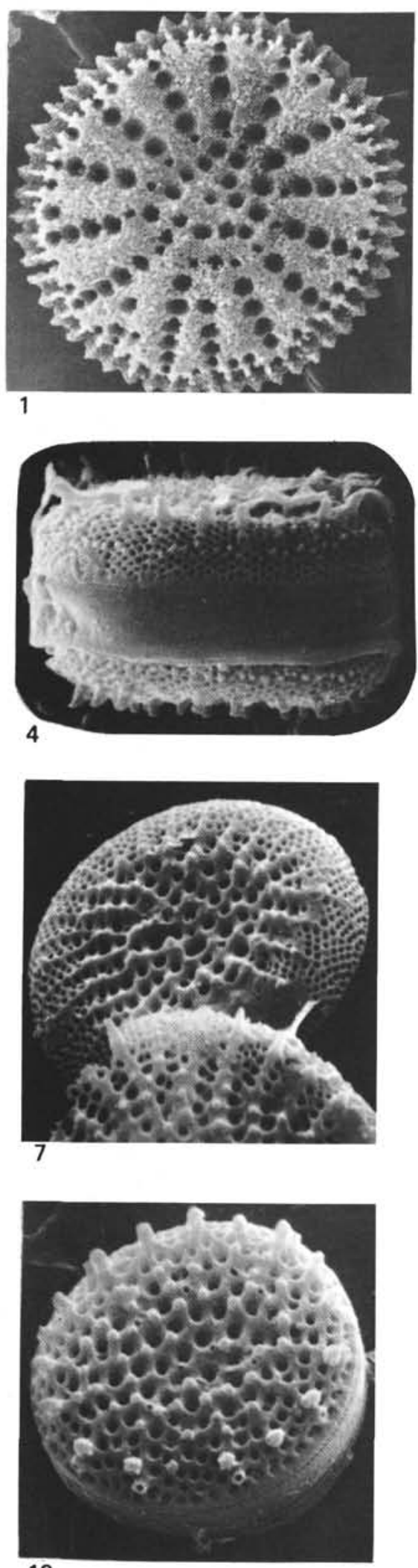

10
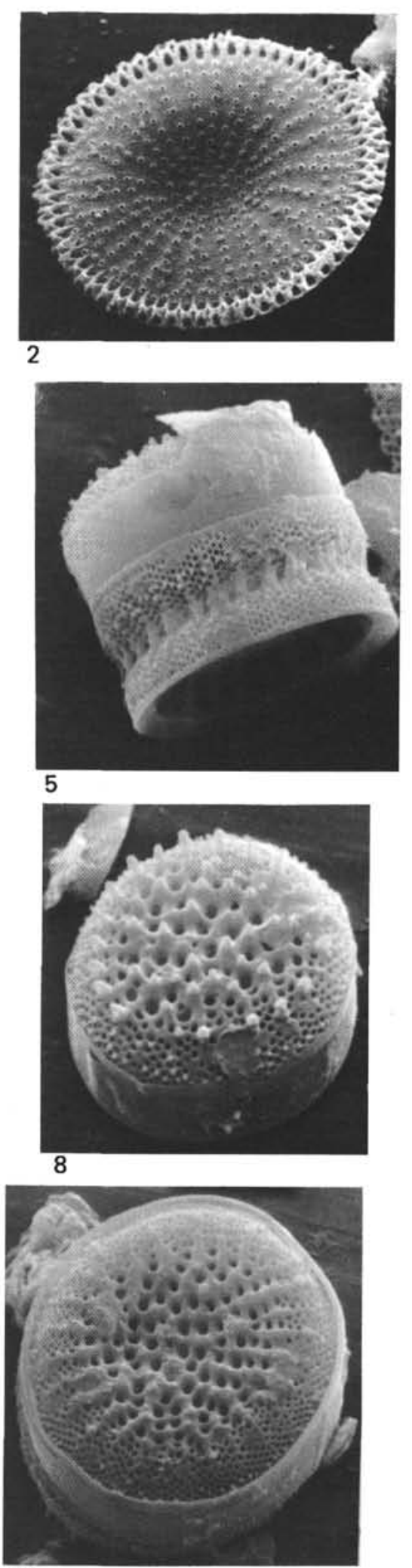

11

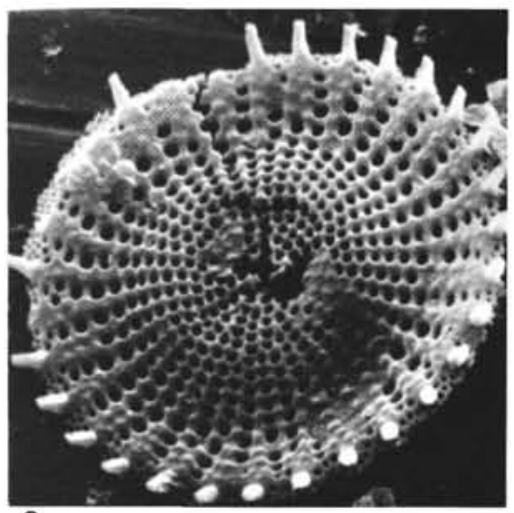

3

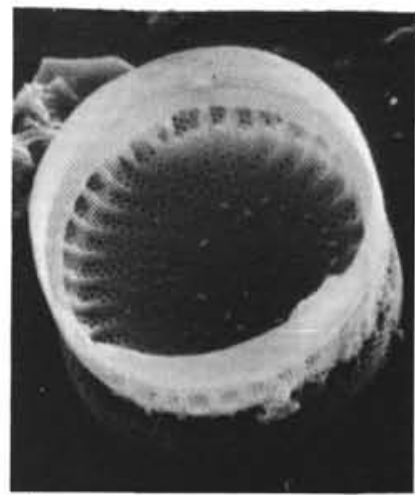

6
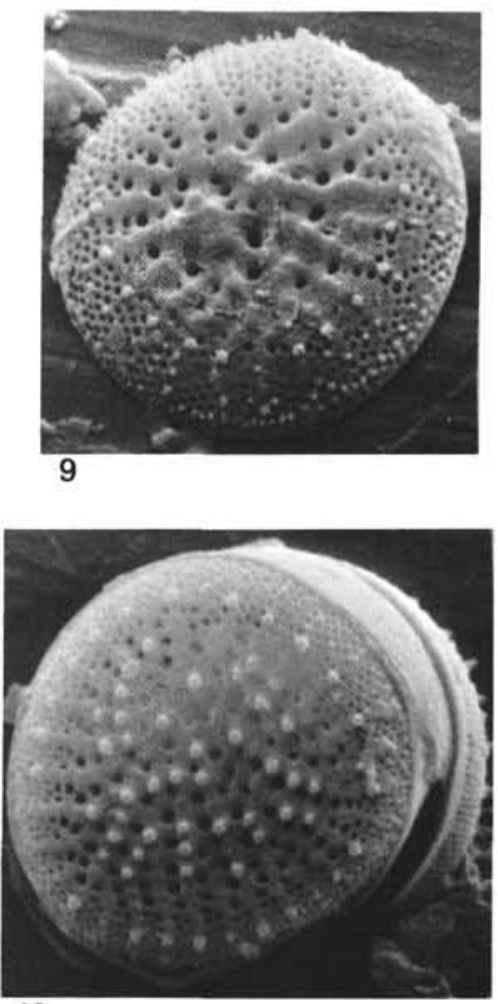

12 
PLATE 9
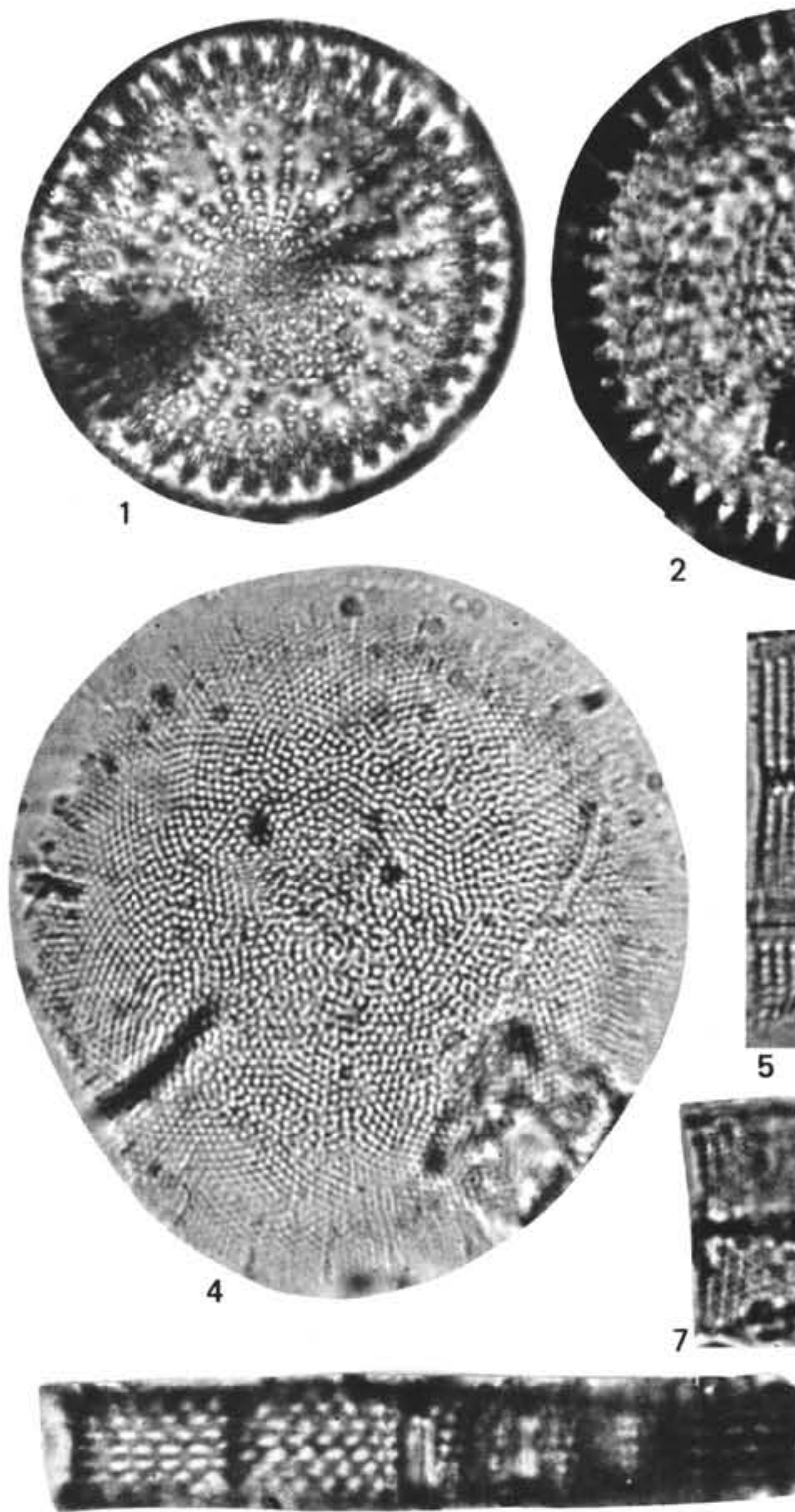

9

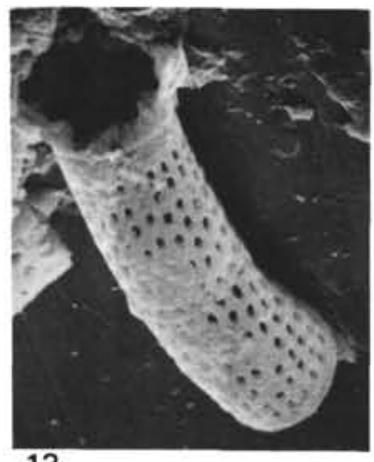

13
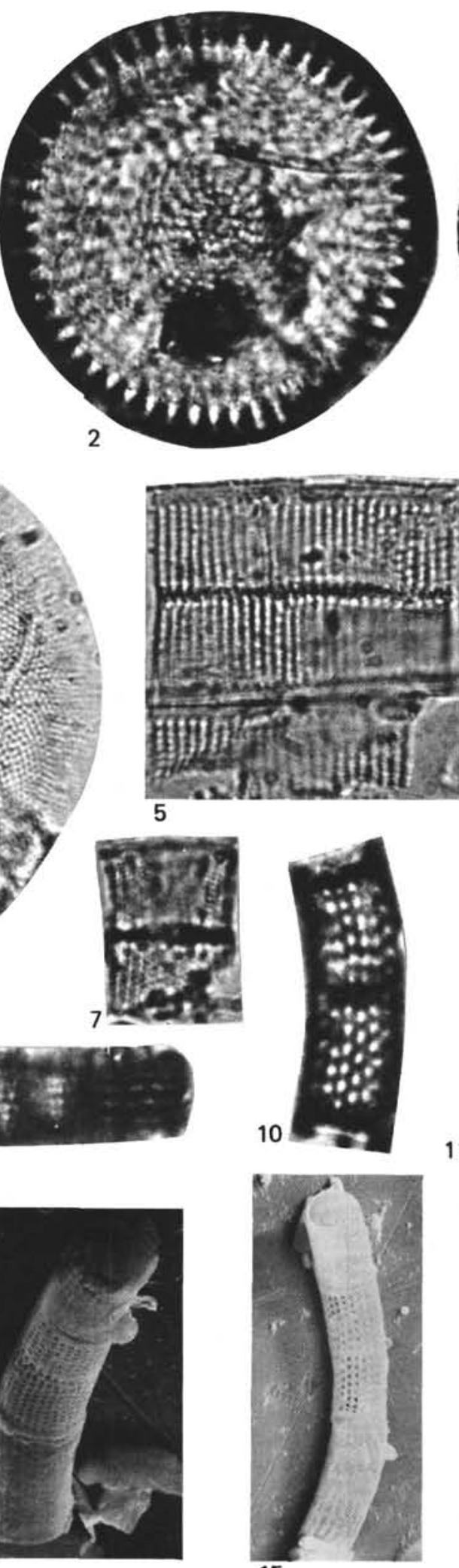

15
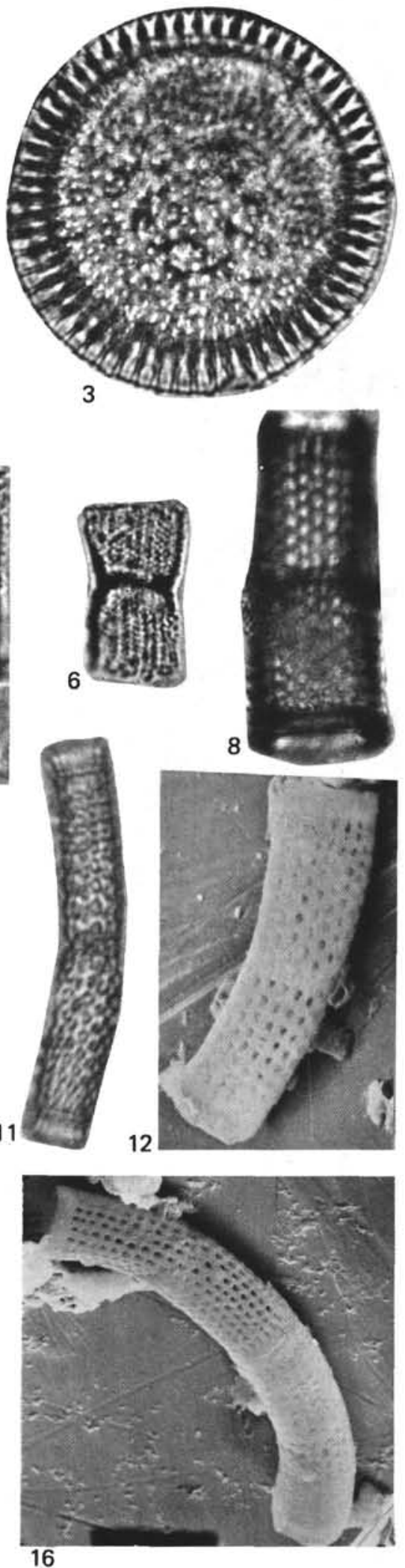
PLATE 10

Figures 1-4 Cyclotella servant-vildary var. elegans Mukhina. Sample 380A-32-1, 6-9 cm.

1. $\times 900$.

2. $\times 1000$.

3, 4. $\times 800$.

Figures 5-15 Cyclotella servant-vildary Mukhina.

5- 10. Sample 380A-32-1, 6-9 cm.

$5,7,9 . \times 1500$.

6. $\times 2000$.

8. $\times 1000$.

10. $\times 800$.

11- 15. Sample $380 \mathrm{~A}-35-3,58-71 \mathrm{~cm}$.

$1,2,4 . \times 1000$.

3. $\times 2000$ (valve in interior view).

\section{PLATE 11}

Figures 1,2, Cyclotella servant-vildary Mukhina.

4-11 1, 2. Sample 380A-36-2, 30-40 cm. $\times 1000$.

4- 11. Sample $380 \mathrm{~A}-35-3,58-71 \mathrm{~cm}$.

4- $6,9 . \times 1000$.

$7,10 . \times 1500$.

8. $\times 1100$.

11. $\times 1400$.

Figure 3 Cyclotella servant-vildary Mukhina f. robusta. Sample 380A-32-1, 6-9 cm. $\times 800$.

Figure 12 Cyclotella servant-vildary var. elegans Mukhina Sample 380A-35-3, 58-71 cm. $\times 700$.

(see p. 932) 
PLATE 10
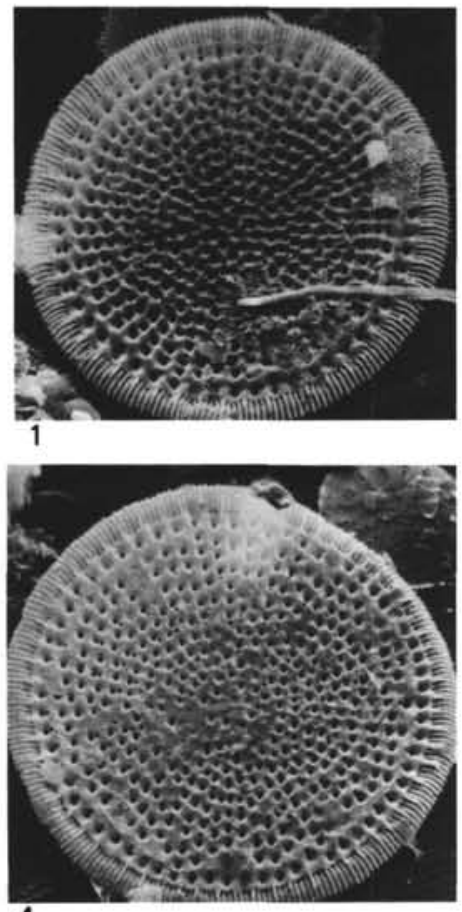

4

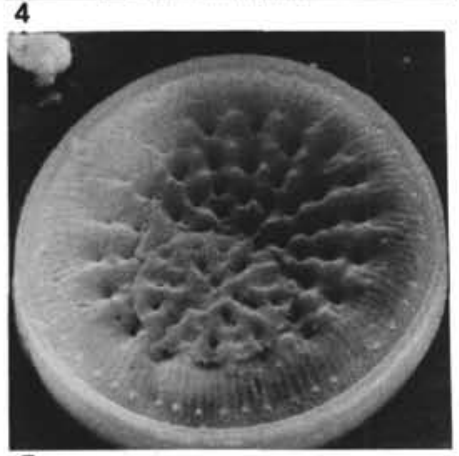

7

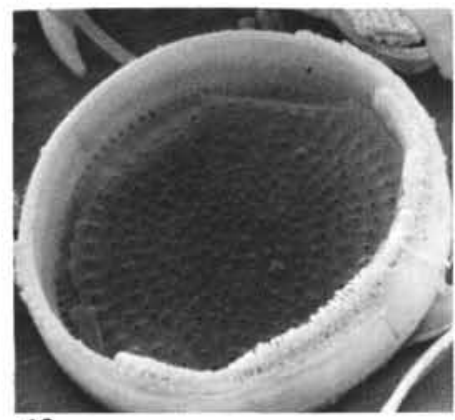

10

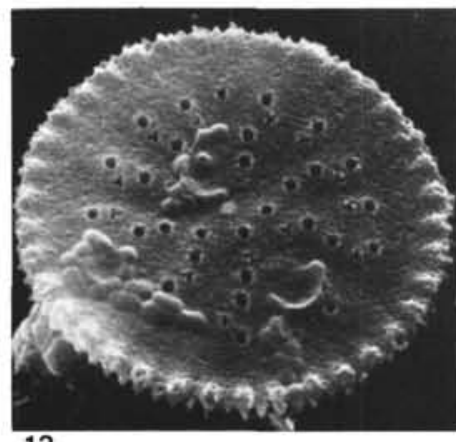

13
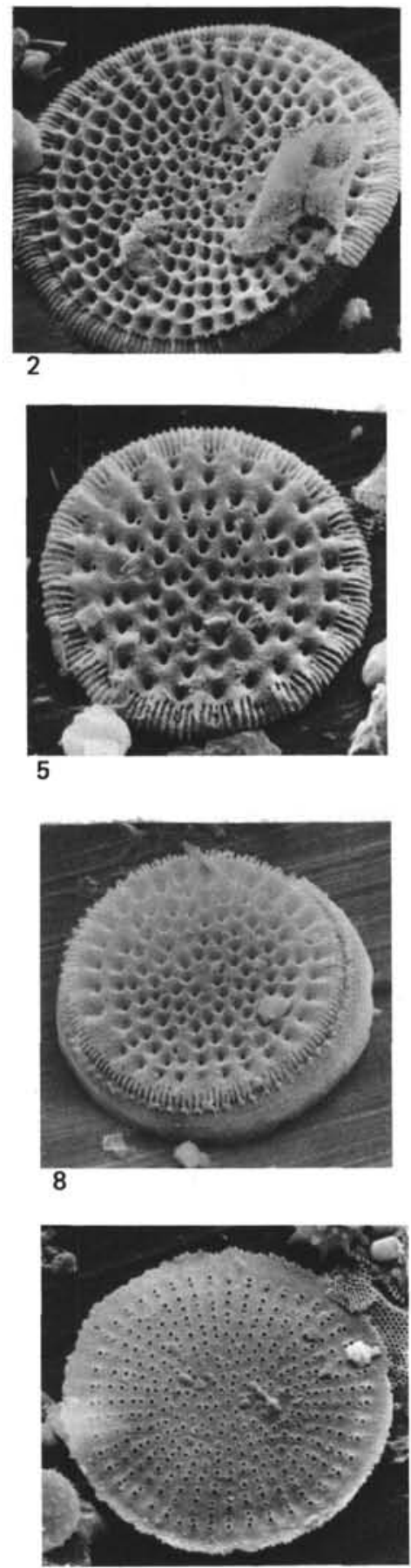

11

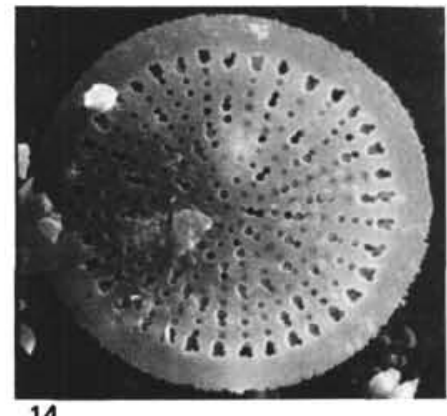

14
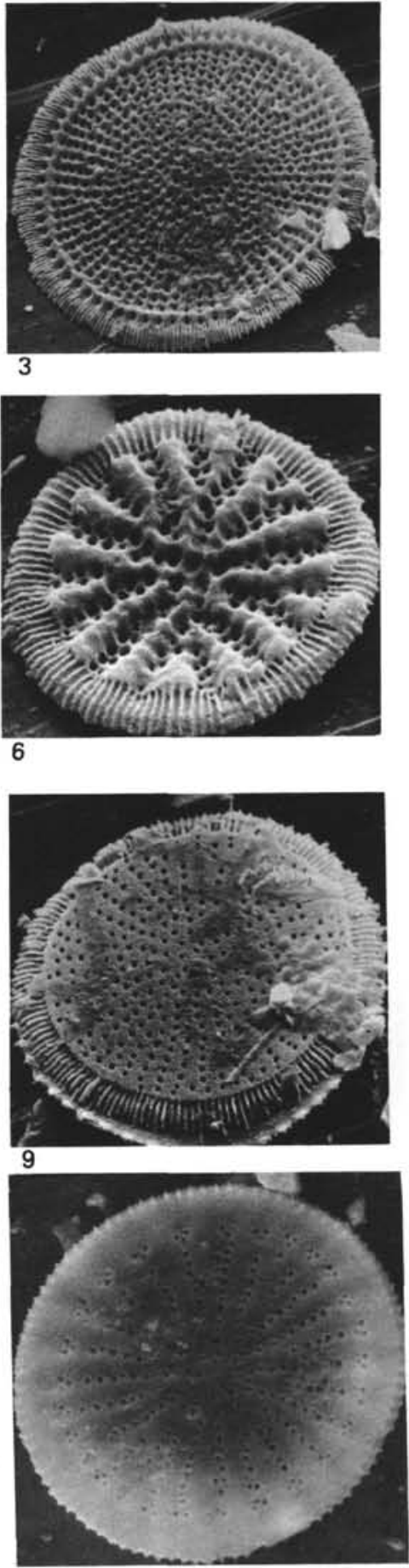

12

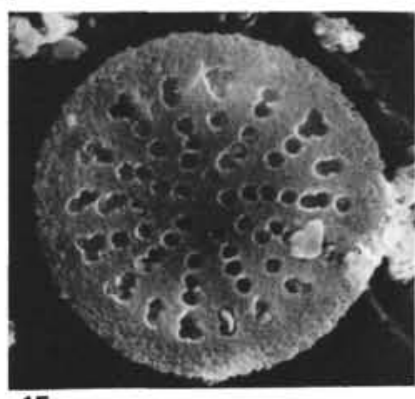

15 


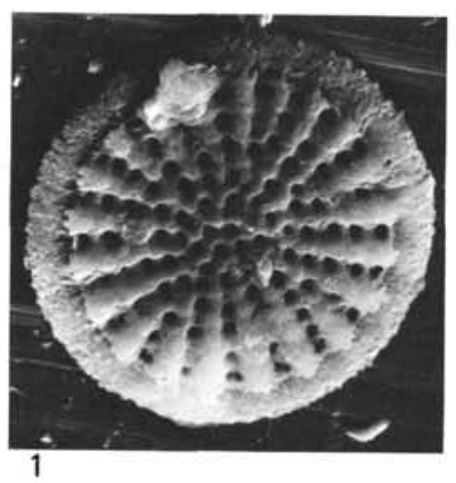

PLATE 11
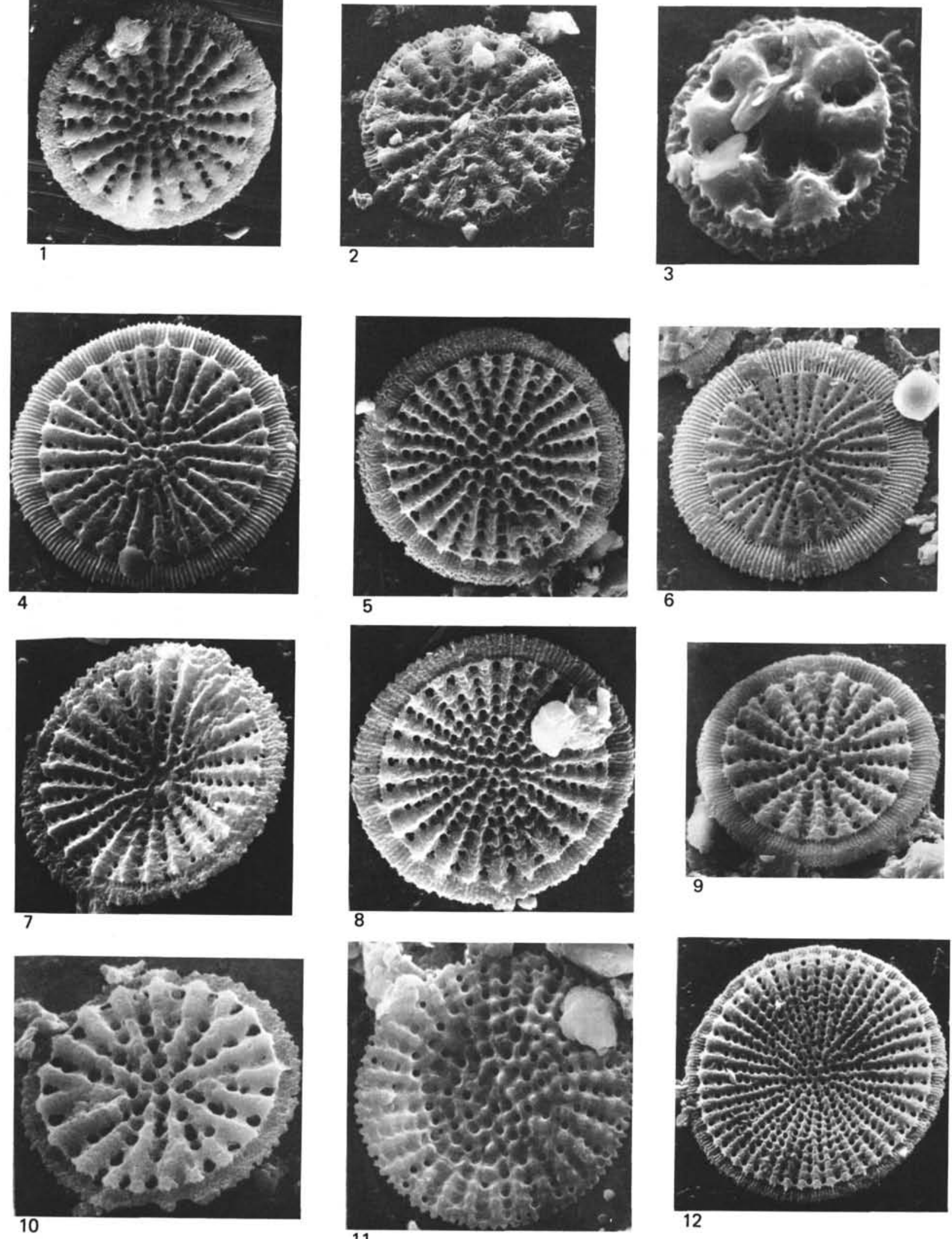


\section{PLATE 12}

Figure $1 \quad$ Stephanodiscus speciosus Mukhina.

Sample $381-23-3,46-53 \mathrm{~cm} . \times 800$.

Figures 2, 3, Melosira hibschii Reich. (2, 3 disk, 6, 7 spores). 6,7 Sample $381-23-3,46-53 \mathrm{~cm}$.

2, 6. $\times 2000$.

3. $\times 1500$.

7. $\times 1300$.

Figure $4 \quad$ Stephanodiscus matrensis Pant.

Sample $381-23-3,46-53 \mathrm{~cm} . \times 4000$.

Figure 5 Thalassiosira? sp.

Sample 381-23-3, 46-53 cm. $\times 900$.

Figures 8,9,11 Melosira praegranulata Jousé.

8, 9. Sample $381-23-3,46-53 \mathrm{~cm} . \times 2000$.

11. Sample $381-25-4,50-65 \mathrm{~cm} . \times 1500$.

Figures 10, Melosira bellicosa Herib.

12-15 10. Sample 381-23-3, 46-53 cm. $\times 2500$.

12, 13. Sample $380 \mathrm{~A}-40-4,6-20 \mathrm{~cm} . \times 1500$.

14, 15. Sample $381-25-4,50-65 \mathrm{~cm}$.

14. $\times 3500$.

15. $\times 2000$.

(see p. 934)

\section{PLATE 13}

Figures 1-9 Stephanodiscus dubius (Fricke) Hust.

Sample 381-23-3, 46-53 cm.

1. $\times 2500$.

$2,3,8 . \times 1500$.

4, 7. $\times 1000$

5, 6. $\times 2000$.

9. $\times 1300$.

$(8,9$ valves in interior view)

Figures 10-12 Stephanodiscus carconensis Grun. Sample 381-23-3, 46-53 cm.

10. $\times 900$.

11. $\times 800$.

12. $\times 1000$.

(see p. 935) 


\section{PLATE 12}
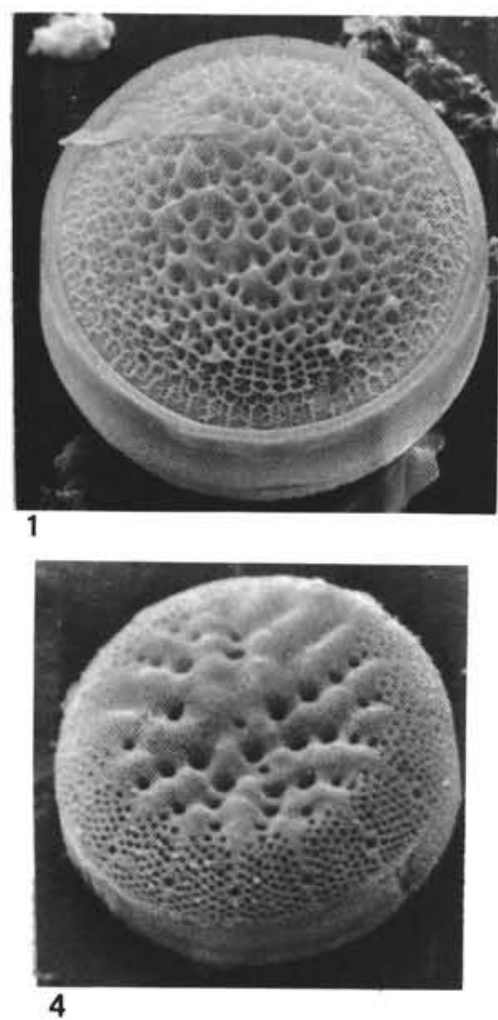
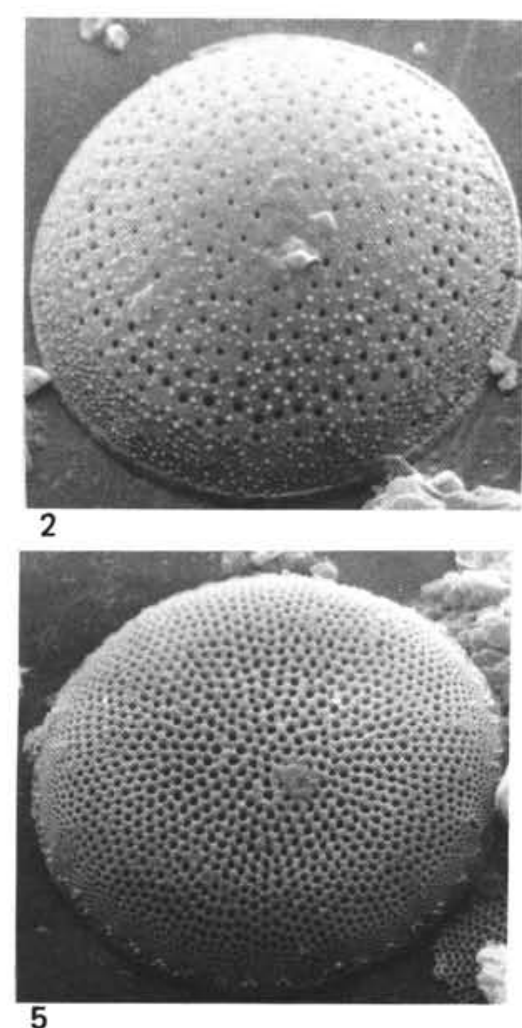
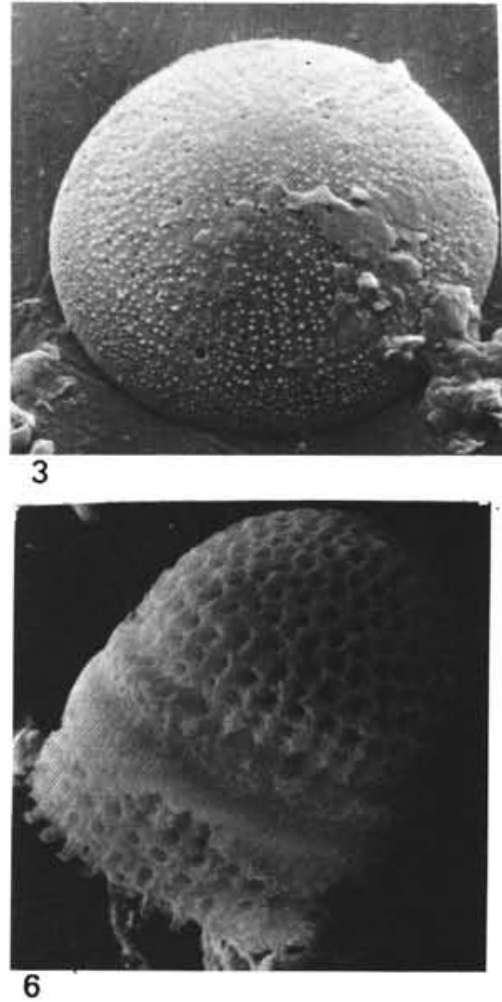
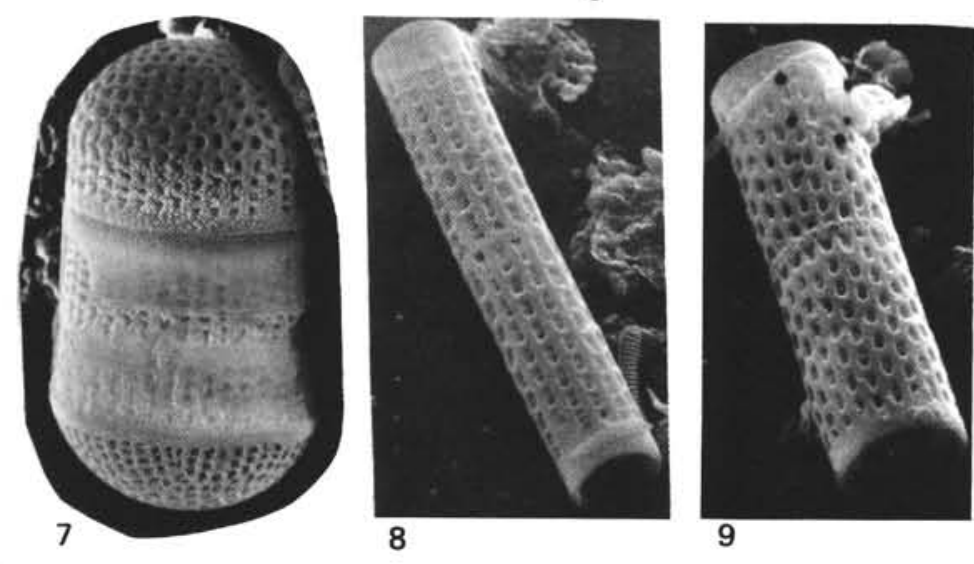

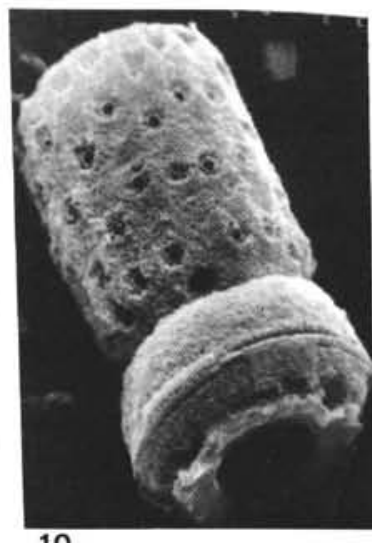

10

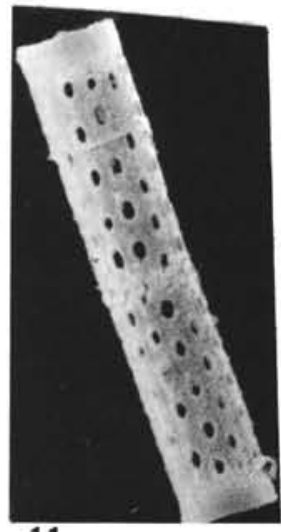

11
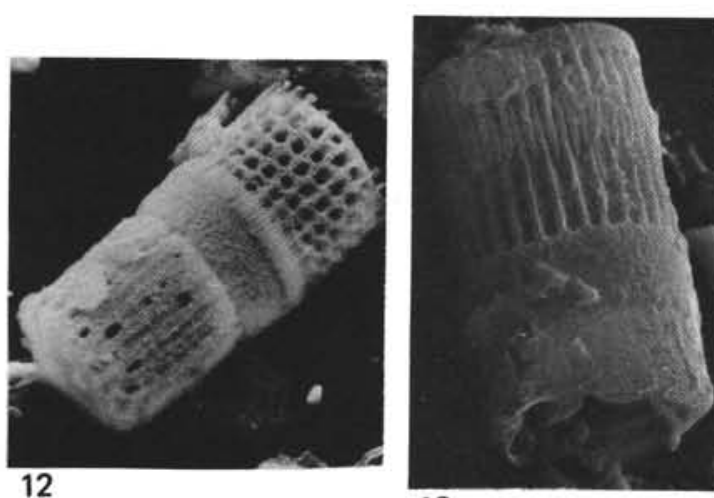

13
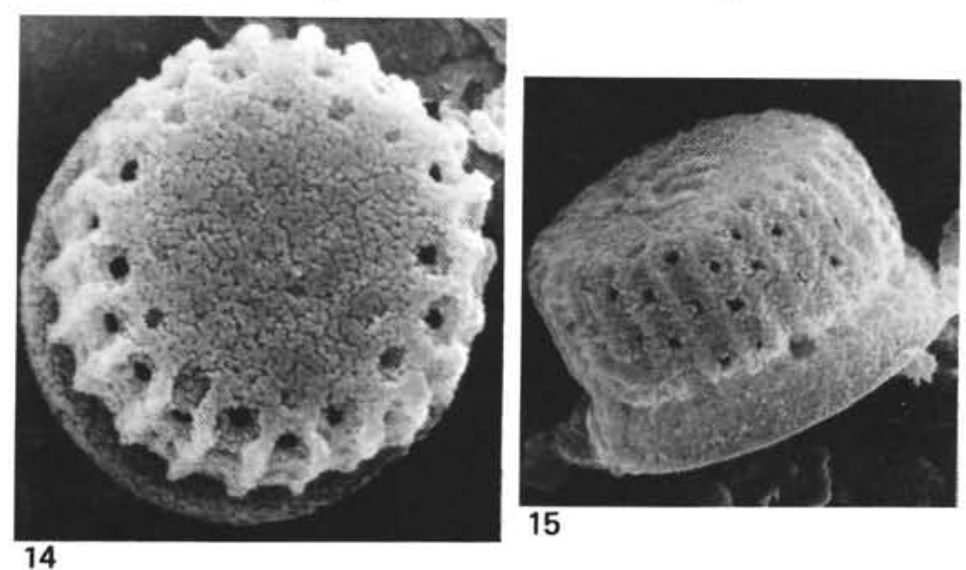

15 

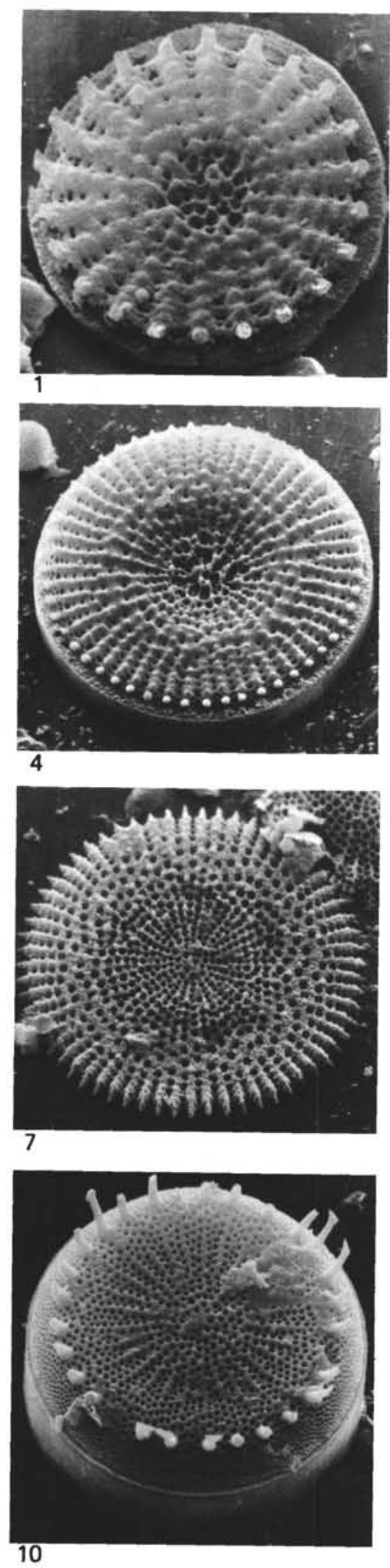

PLATE 13
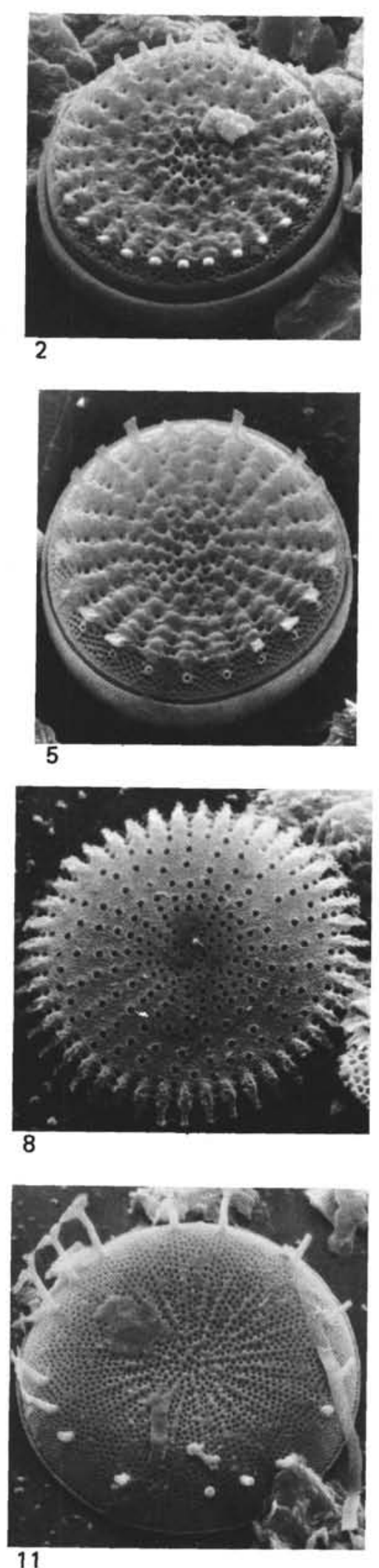
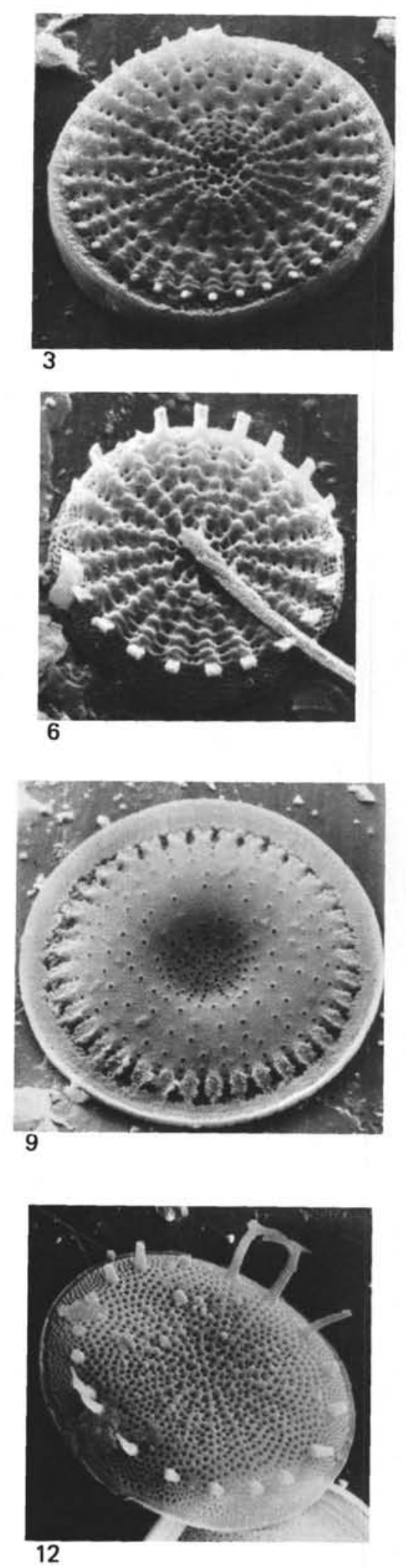


\section{PLATE 14}

Figures 1,2 Cyclotella servant-vildary var. elegans Mukhina. Sample 380A-32-1, 6-9 cm. $\times 1000$.

Figures 3, 4, Cyclotella servant-vildary Mukhina.

7, $8,7,8$. Sample 380A-36, CC.

3. $\times 1000$.

7, 8. $\times 1500$.

4. $380 \mathrm{~A}-39-3,99-101 \mathrm{~cm} . \times 1000$.

Figures 5,6 Cyclotella comta var. radiosa Grun.

Sample 380A-36-3, 80-82 cm. $\times 1000$.

Figures 9, 10 Cyclotella servant-vildary Mukhina f. robusta.

Sample 380A-36, CC.

9. $\times 2500$.

10. $\times 3500$.

Figure $11 \quad$ Stephanodiscus niagarae Ehr.

Sample 380A-36, CC, $\times 700$.

Figures 12, 13 Coscinodiscus aff. variabilis Freng.

Sample 380A-38036, CC.

12. $\times 1500$.

13. $\times 800$.

PLATE 15

Figure $1 \quad$ Stephanodiscus astraea (Ehr.) Grun. Sample 380A-17-2, 111-123 cm. $\times 800$.

Figures 2-10 Cyclotella corona Mukhina.

2- 8. Sample $380 \mathrm{~A}-17-2,111-123 \mathrm{~cm}$.

2- 4, 8. $\times 1500$.

5. $\times 1300$.

6, 7. $\times 2000$.

9, 10. Sample $380 \mathrm{~A}-17-1,50-52 \mathrm{~cm} . \times 1000$.

Figure $11 \quad$ Stephanodiscus hantzschii Grun.

Sample 380 A-17-1, 50-52 cm. $\times 1000$.

Figures 12-14 Rhaphoneis linearis Grun.

Sample 380A-17-2, 111-123 cm.

12. $\times 1400$.

13. $\times 1500$.

14. $\times 5000$.

(see p. 938) 
PLATE 14
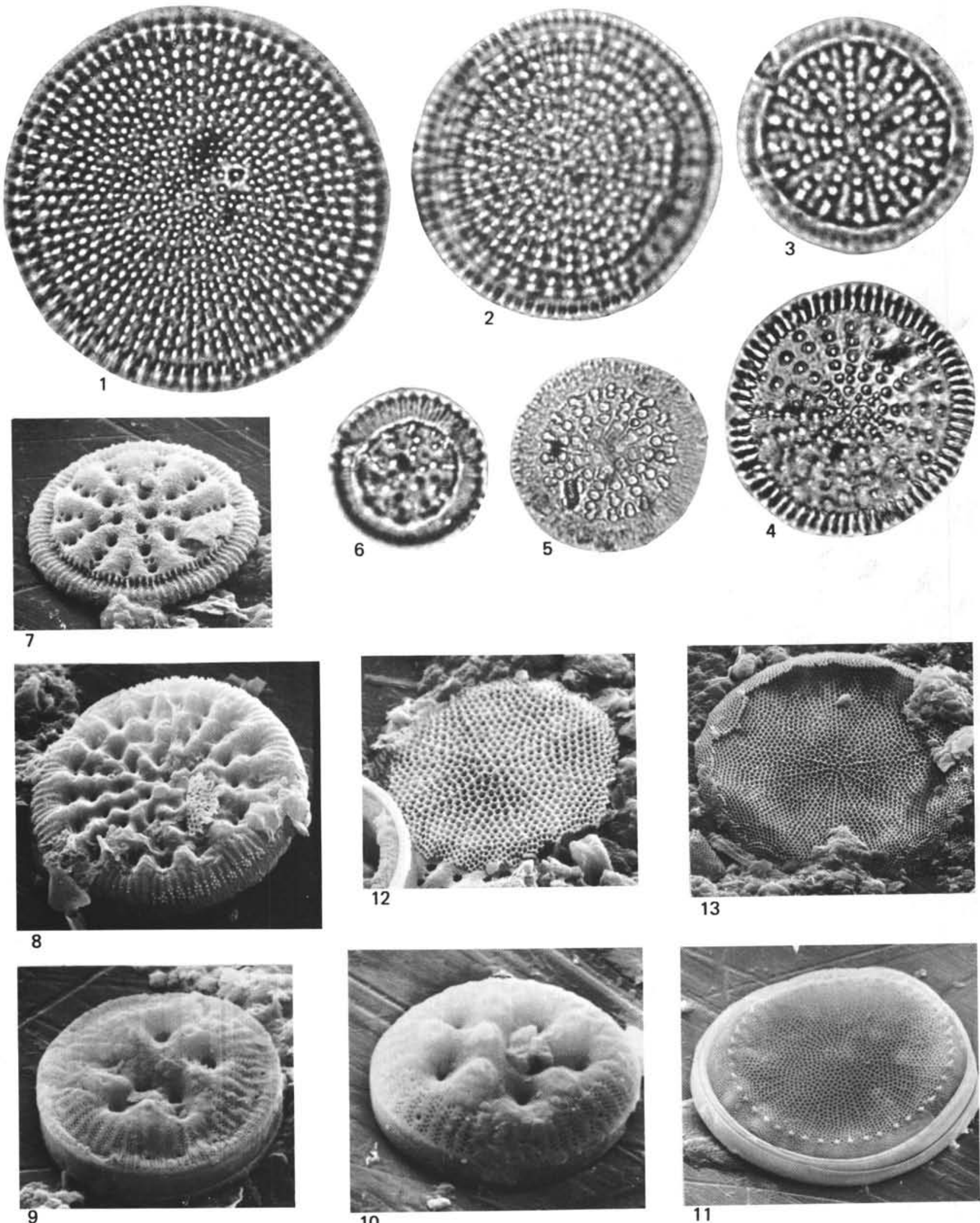

11 
PLATE 15
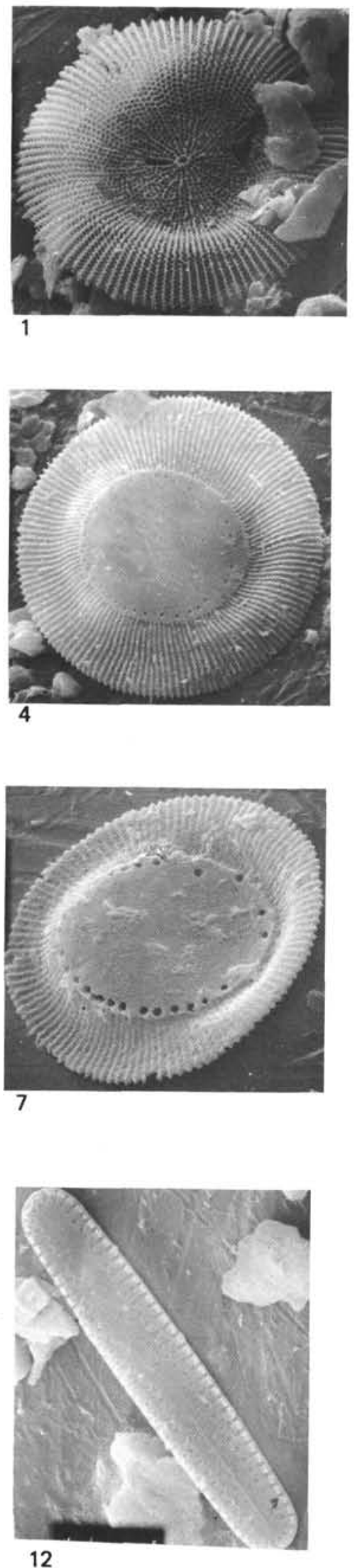

13
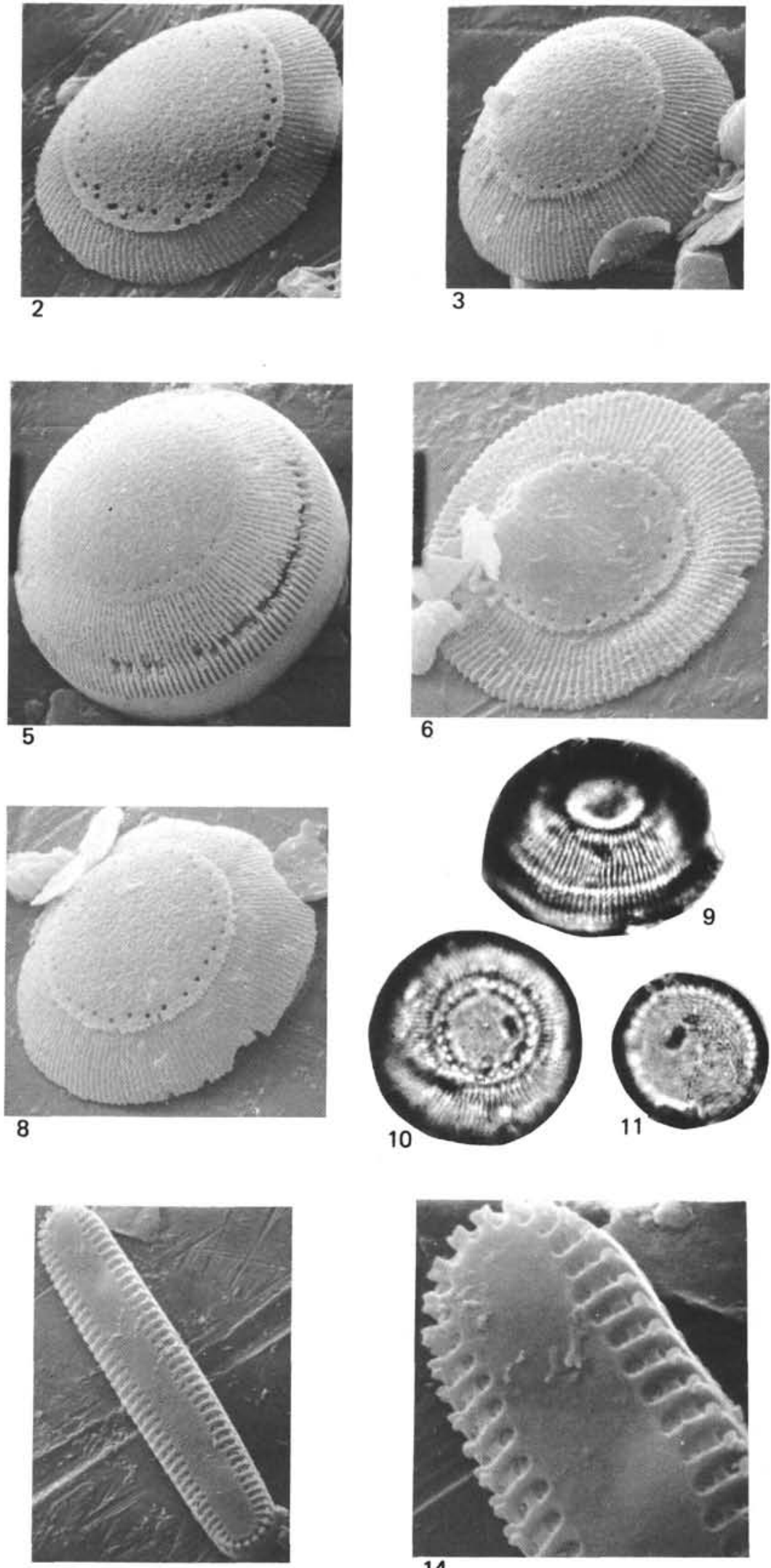


\section{PLATE 16}

Figures 1-10 Coscinodiscus normannii Greg.

1- 9. Sample $381-2-2,124-144 \mathrm{~cm}$.

$1,3,5,7 . \times 1000$.

2. $\times 600$.

4. $\times 1200$.

6, 9. $\times 2000$.

8. $\times 3000$ (detail).

10. Sample 379 A-29-3, $145-147 \mathrm{~cm} . \times 1000$.

Figures 11, 12 Coscinodiscus sp.

Sample 380A-39-6, 50-52 cm.

11. $\times 800$.

12. $\times 5000$ (detail).

(see p. 940)

\section{PLATE 17}

Figures 1-3 Stephanodiscus astraea var. intermedia Fricke. Sample 380-33-3, 95-110 cm. $\times 3000$.

Figures 4-10 Stephanodiscus astraea (Ehr.) Grun.

4- 7. Sample $380-33-3,95-110 \mathrm{~cm} . \times 1000$.

8 , 9. Sample $379 \mathrm{~A}-24-6,21-23 \mathrm{~cm} . \times 1000$.

10. Sample $380-18-6,130-148 \mathrm{~cm} . \times 1000$.

Figures 11, 12 Stephanodiscus gravitoides Mukhina.

11. Sample 379 A-24-6, $21-23 \mathrm{~cm} . \times 2000$.

12. Sample $380-18-6,130-148 \mathrm{~cm} . \times 1000$.

(see p. 941) 

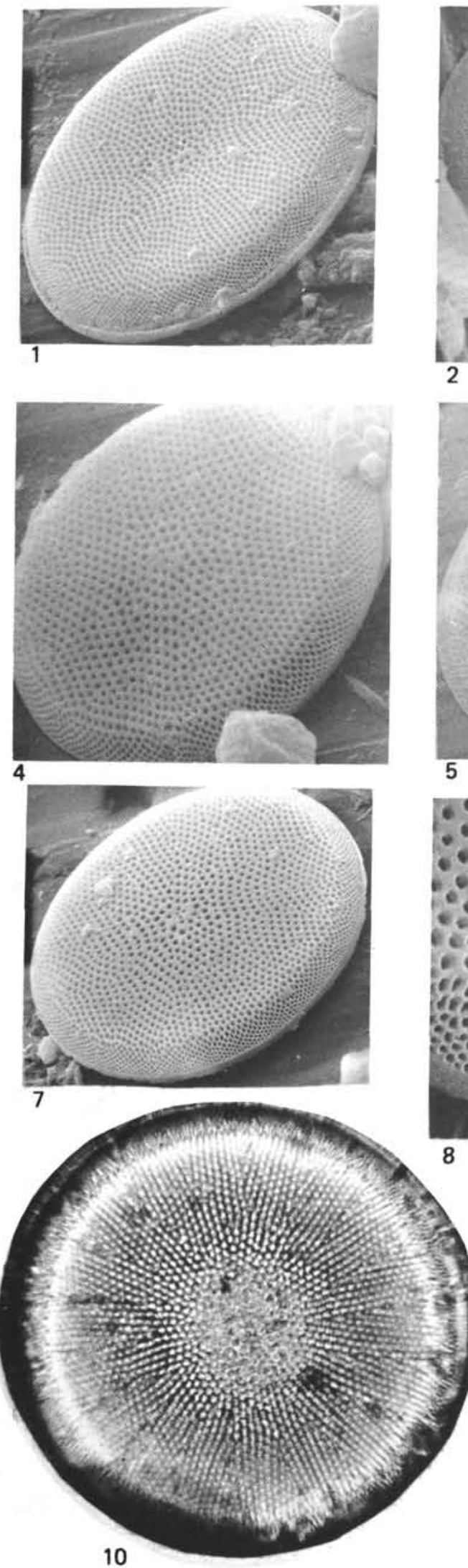
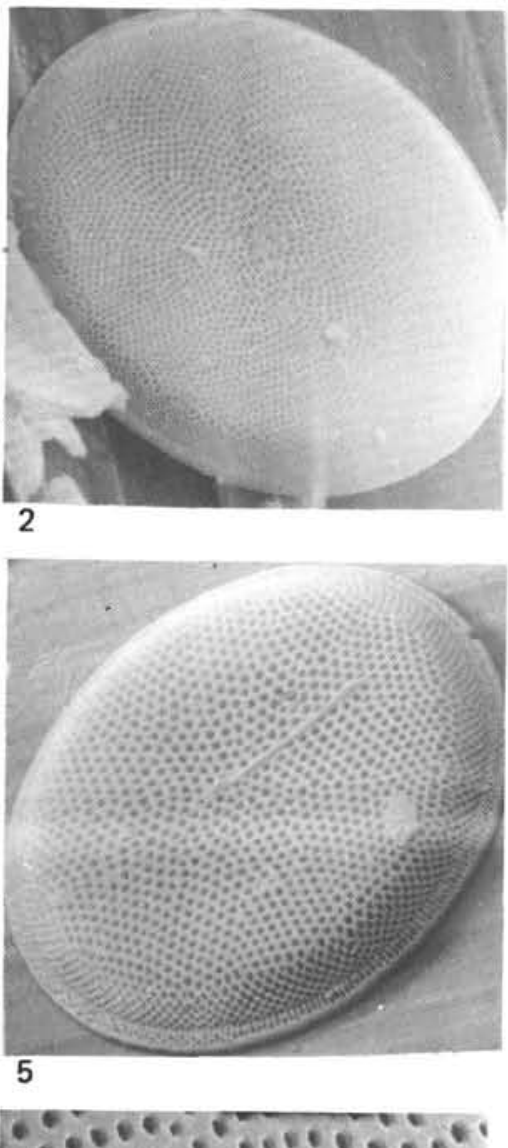

cectecesteces

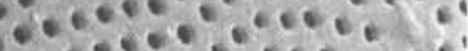

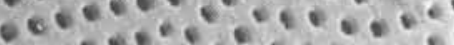
cotectecteces $-c^{2} c^{2} e^{2}=e^{2}$ coeve ece

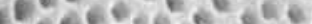
ef eces ecesed

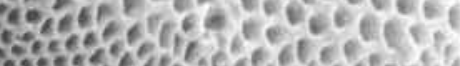

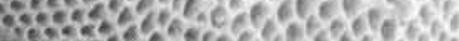

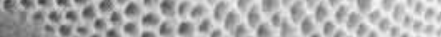
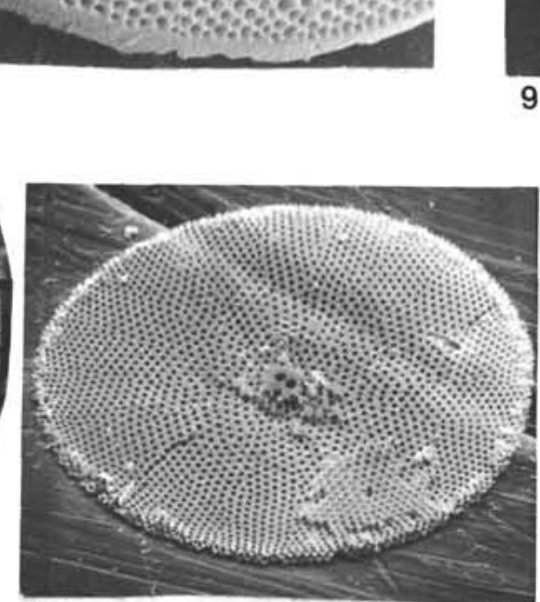

11
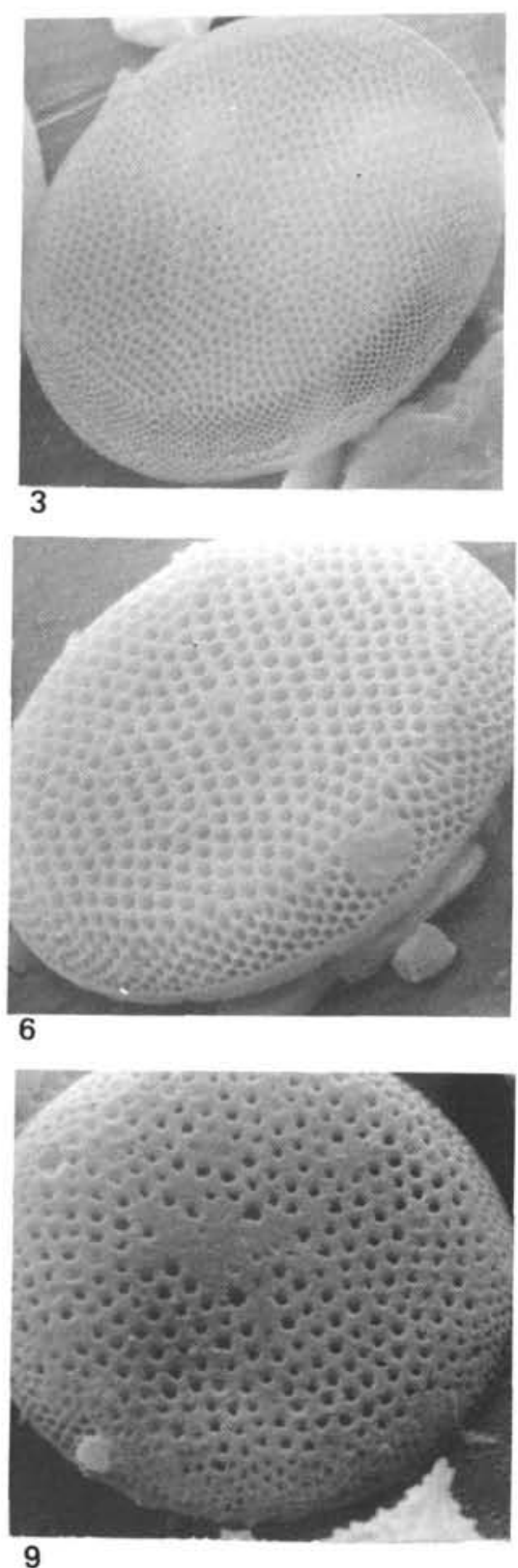

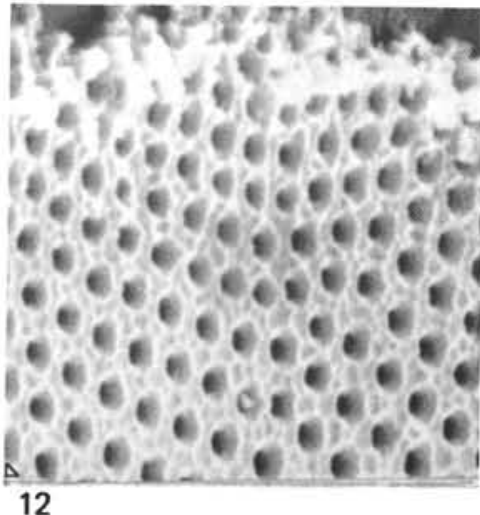


PLATE 17

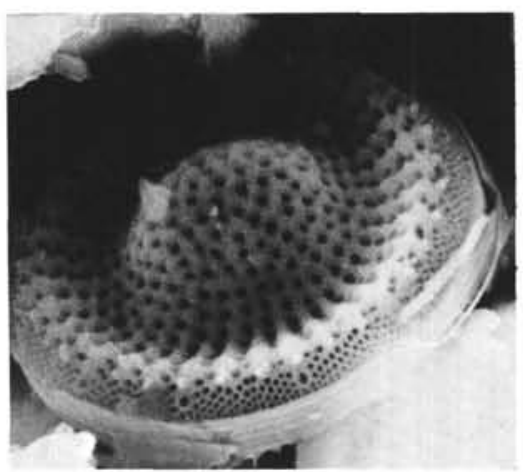

1
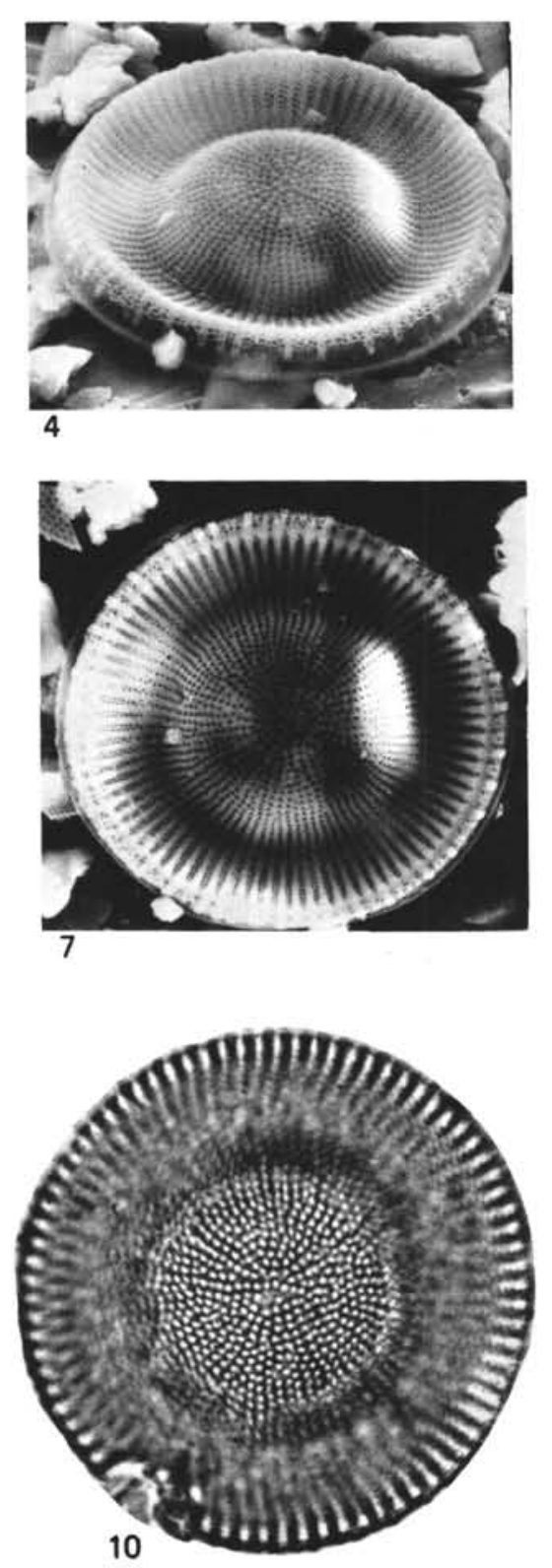
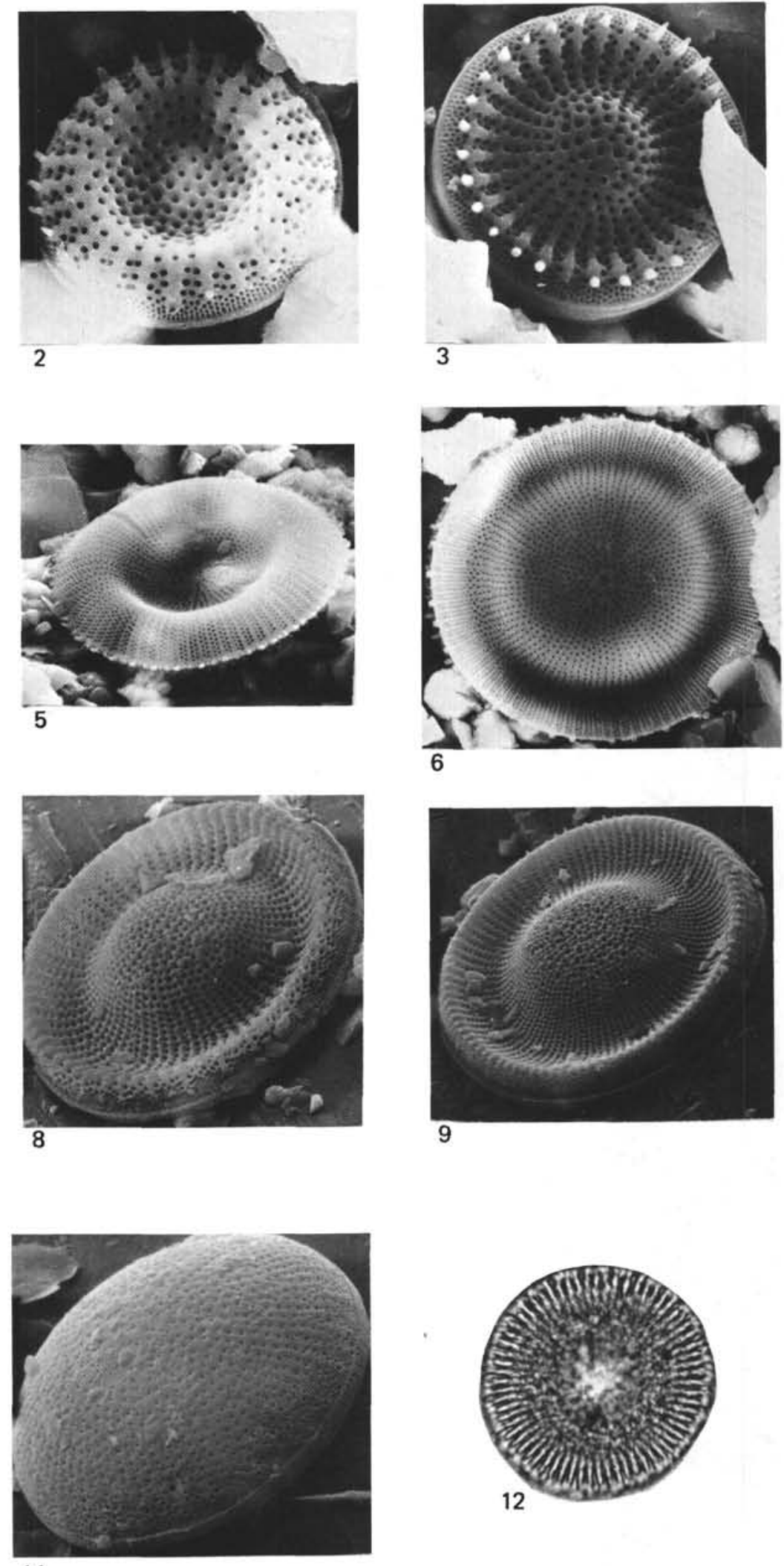
PLATE 18

Figures 1-6, Coscinodiscus normannii Greg.

$110-12$

6. Sample $380-35-3,19-42 \mathrm{~cm}$.

1- 3. $\times 1000$.

4, 6. $\times 800$ (6 valve in interior view)

5. $\times 700$.

10- 12. Sample 379A-24-6, $21-23 \mathrm{~cm}$.

10. $\times 1300$.

$11,12 . \times 1500$.

Figures 7,8 Coscinodiscus sp.

Sample 380-35-3, 19-42 cm.

7. $\times 1000$.

8. $\times 5000$ (detail).

Figure 9 Thalassiosira subsalina Pr.-Lavr.

Sample. 380-35-3, 19-42 cm. $\times 1500$.

\section{PLATE 19}

Figures 1-5 Thalassiosira aff. oestrupii (Ostf.) Pr.-Lavr.

Sample 379A-10-5, 13-20 cm.

$1,5 . \times 2500(5$ valve in interior view)

2, 4. $\times 1500$.

$3, \times 2000$.

Figures 6-9 Cyclotella caspia Grun. Sample 379A-10-5, 13-20 cm.

6. $\times 5000$ (valve in interior view).

7. $\times 4500$.

8. $\times 4000$.

9. $\times 3500$.

Figures 10,11 Archaeomonas sp.

10. Sample 379 A $-10-5,13-20 \mathrm{~cm} . \times 2500$.

11. Sample 380-7, CC. $\times 3000$.

Figure 12 Cyclotella kutzingiana Thw.

Sample 379 A-10-5, $13-20 \mathrm{~cm} . \times 4000$.

Figure 13 Achnanthes lanceolata (Breb.) Grun. Sample 379A-10-5, 13-20 cm. $\times 3000$.

Figures 14, 15 Rhaphoneis sp.

Sample 379A-10-5, 13-20 cm.

14. $\times 4000$.

15. $\times 600$.

(see p. 944) 
PLATE 18
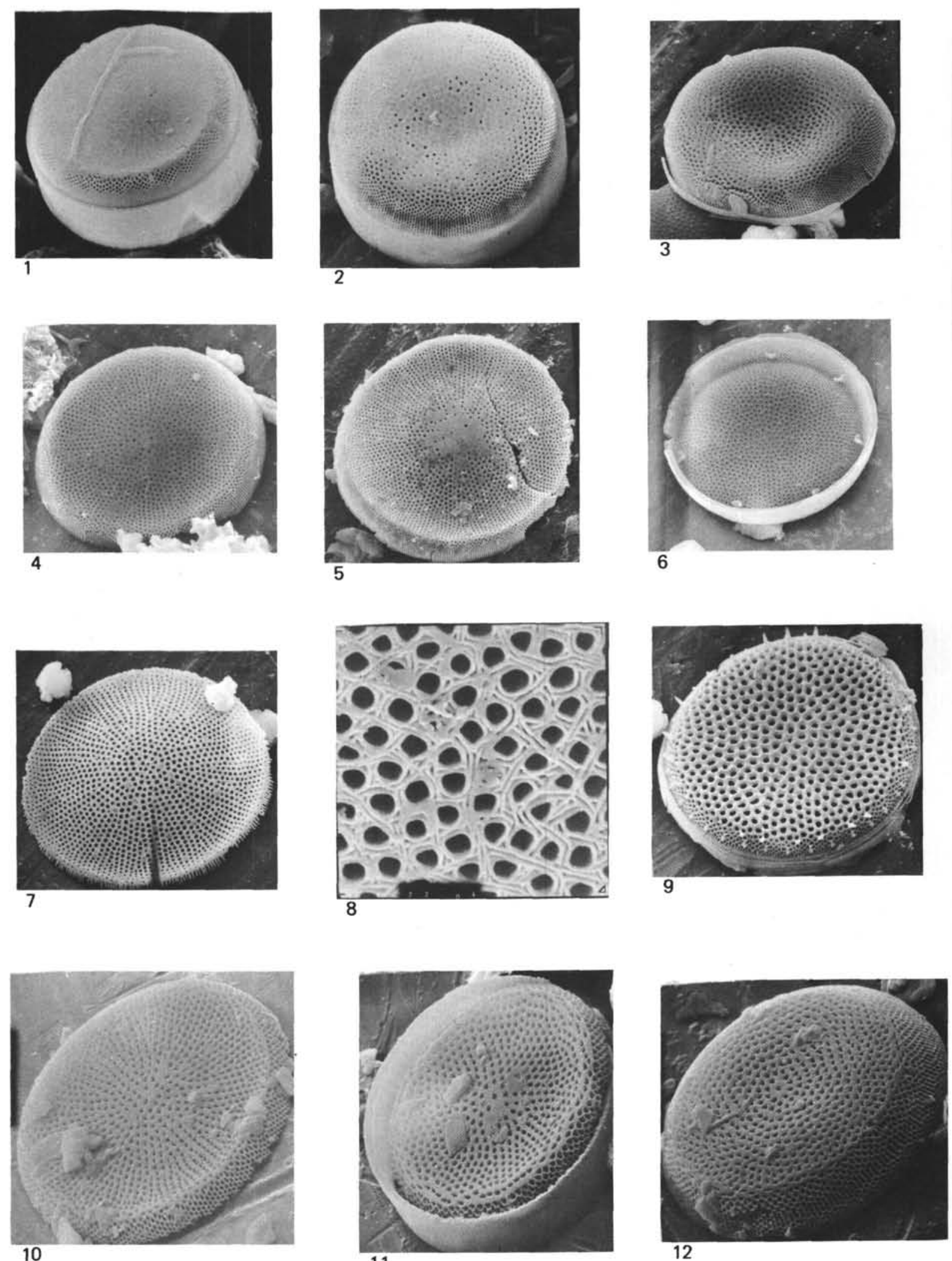

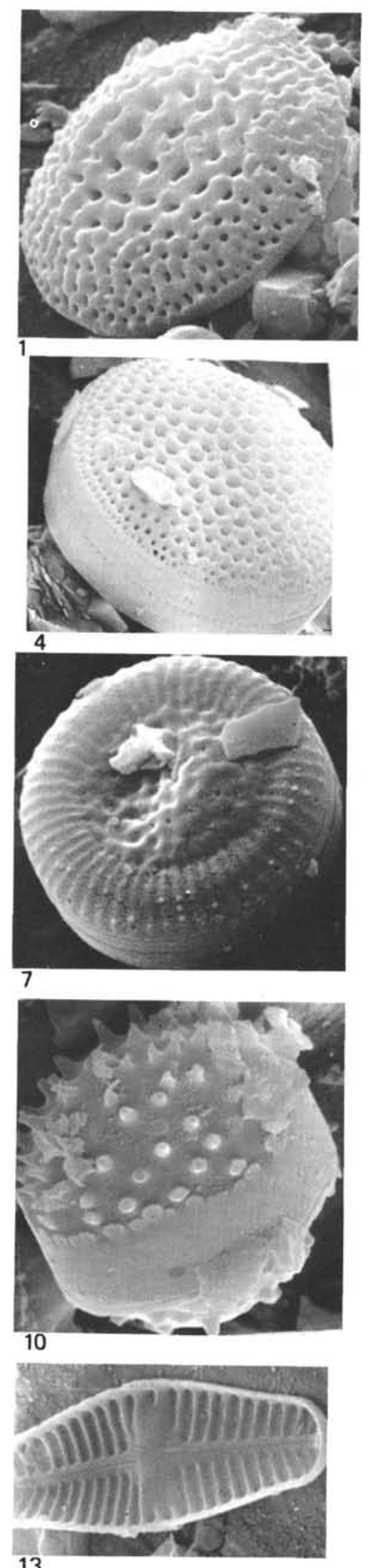

PLATE 19
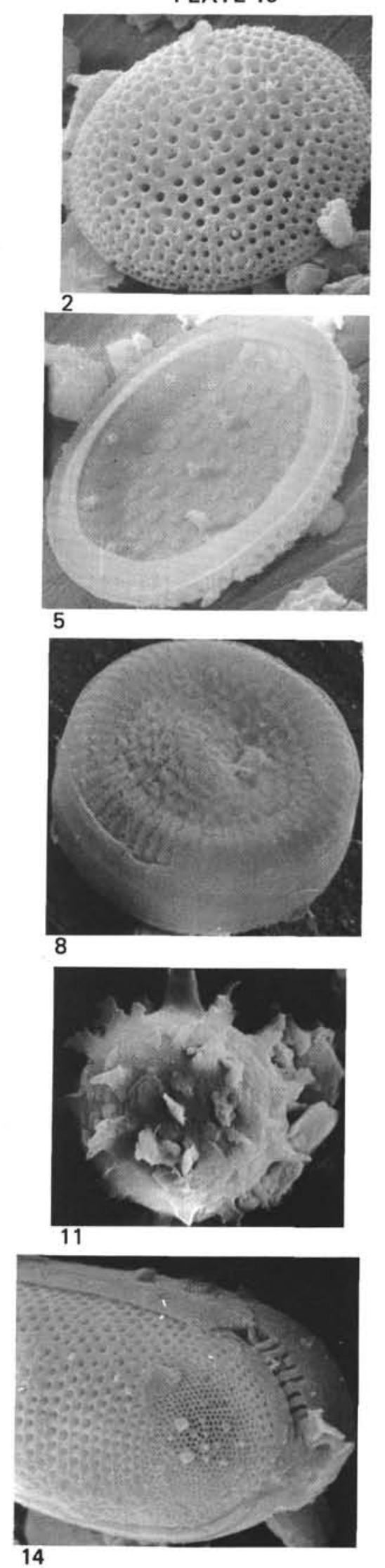
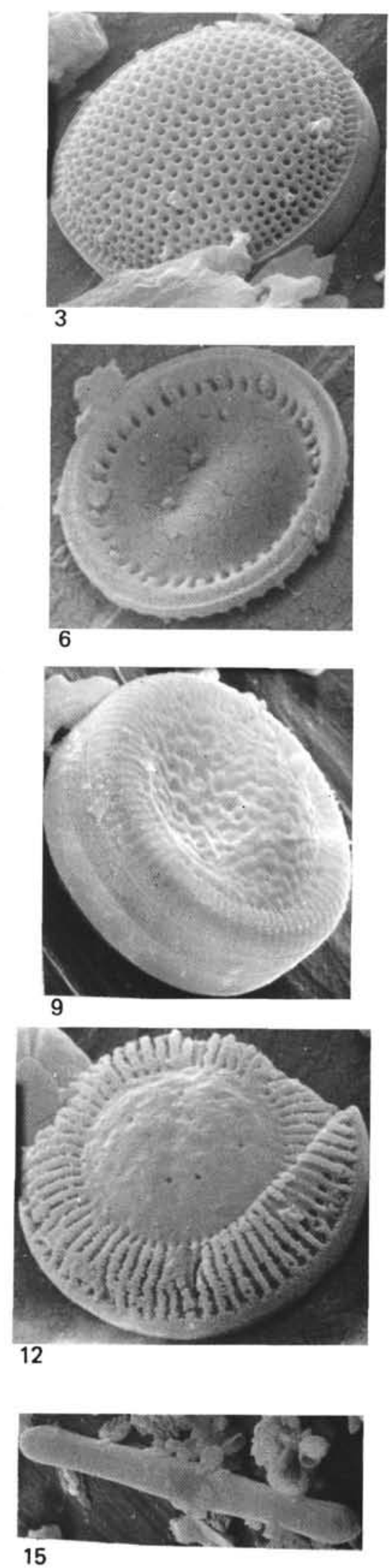

15 
PLATE 20

Figures 1-8 Cyclotella kutzingiana Thw.

Sample 379A-8-2, 10-12 cm.

$1,2,5 . \times 2500$.

3. $\times 2000$.

4, 7. $\times 3500$.

6. $\times 1500$.

8. $\times 3000$.

Figures 9, 10 Cyclotella caspia Grun.

9. Sample $380-7$, CC. $\times 5000$ (valve in interior view).

10. Sample 379 A-8-2, $10-12 \mathrm{~cm} . \times 2000$.

Figure 11 Diploneis elliptica (Ktz.) Cleve.

Sample 379A-8-2, 10-12 cm. $\times 7000$.

Figures 12, 13 Stephanodiscus astraea (Ehr.) Grun.

Sample 379A-8-2, 10-12 cm.

12. $\times 3000$.

13. $\times 2000$.

(see p. 946)

\section{PLATE 21}

Figures 1-3 Stephanodiscus astraea (Ehr.) Grun.

Sample 380-7, CC.

$1,2 . \times 2500$.

3. $\times 2000$.

Figures 4, 5.2R rchaemonas sp.

Sample 380-7, CC.

4. $\times 4500$.

5. $\times 3000$.

Figure $6 \quad$ Melosira moniliformis v. hispida Hust.?.

Sample $380-7$, CC. $\times 1500$.

Figures 7,8 Stephanodiscus hantzschii Grun.

Sample 380-7, CC. $\times 3000$.

(8-valve in interior view)

Figures 9-12 Thalassiosira subsalina Pr.-Lavr.

Sample 380-7, CC.

9. $\times 1000$.

$10,11 . \times 1500$.

12. $\times 2000$.

(see p. 947) 
PLATE 20
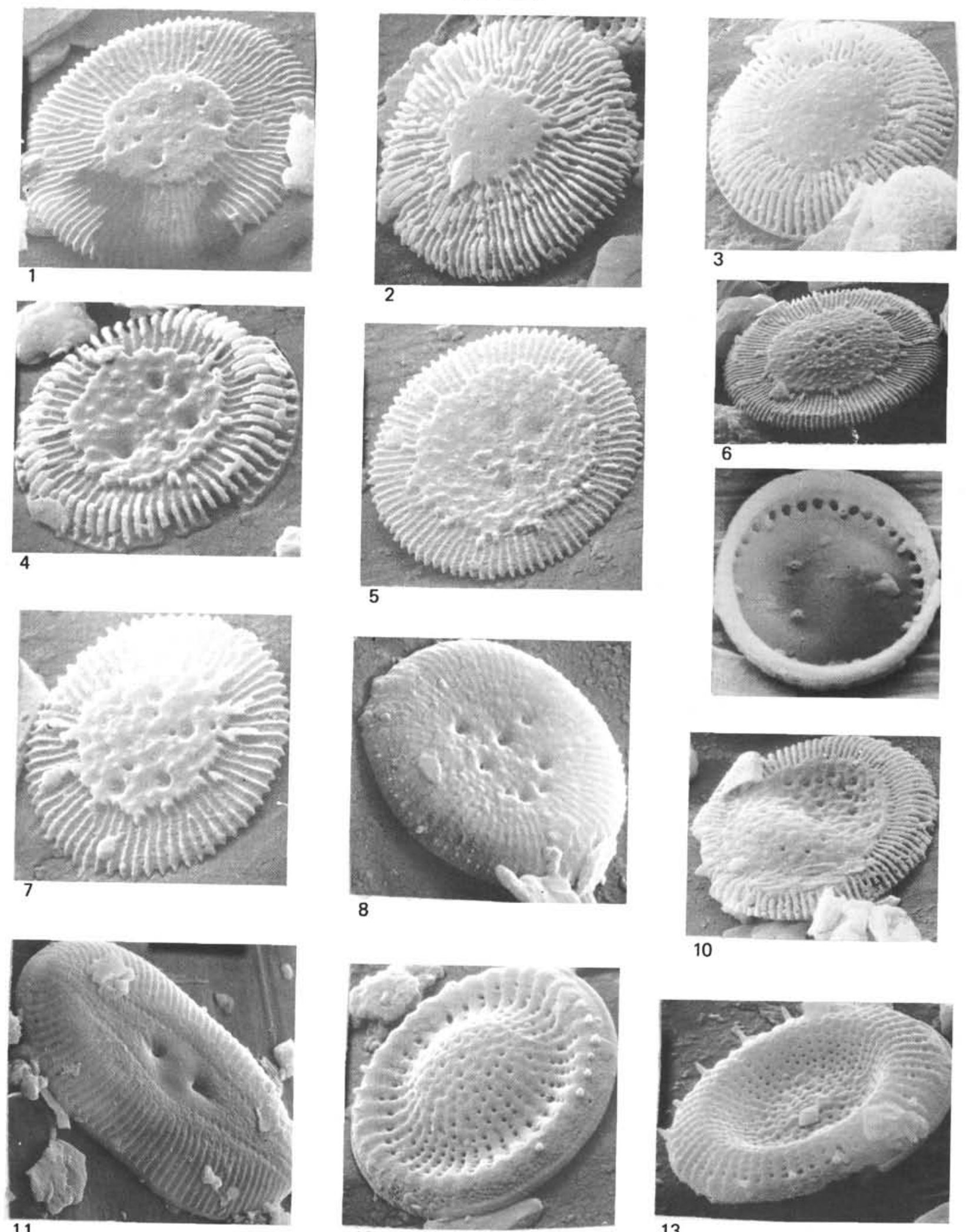
PLATE 21

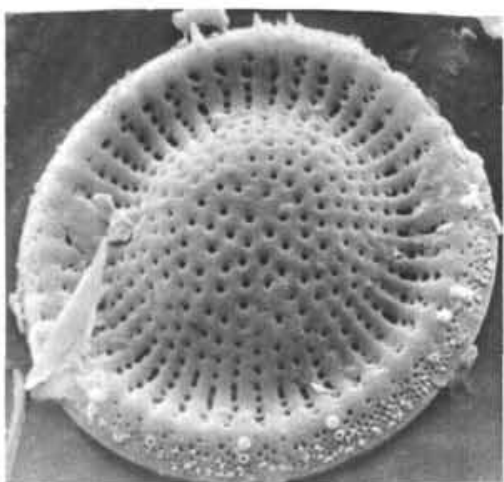

1
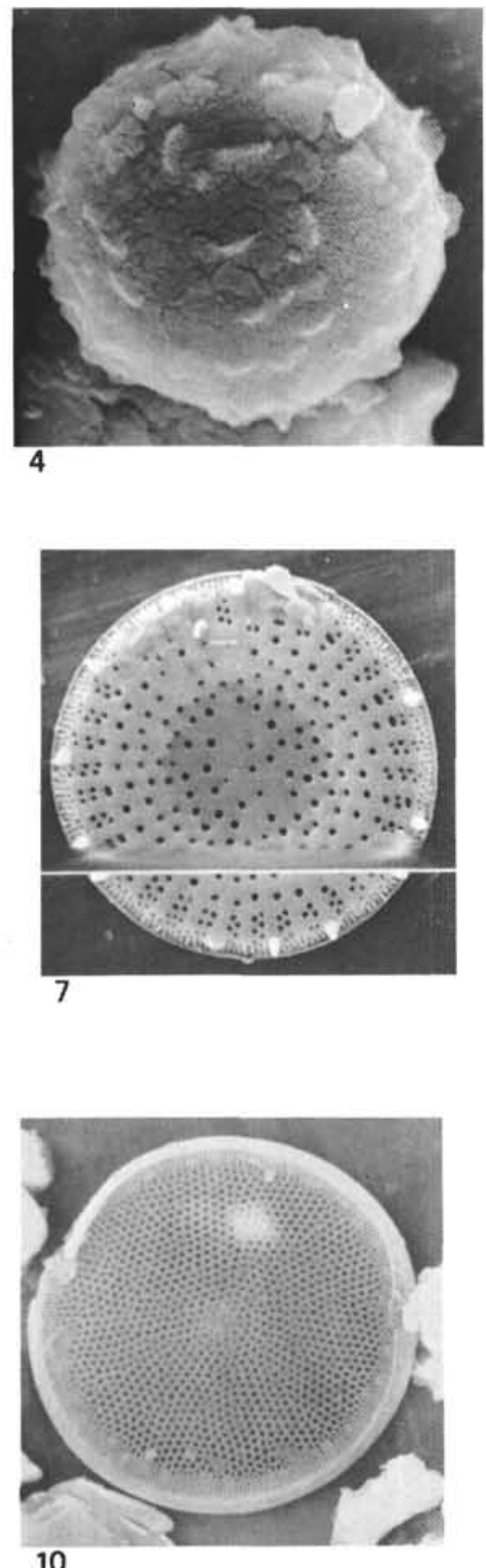
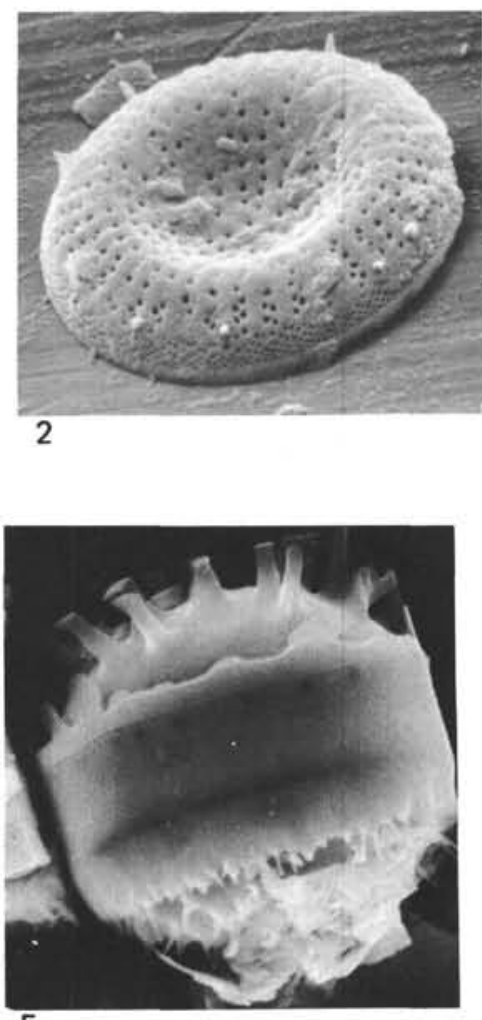

5
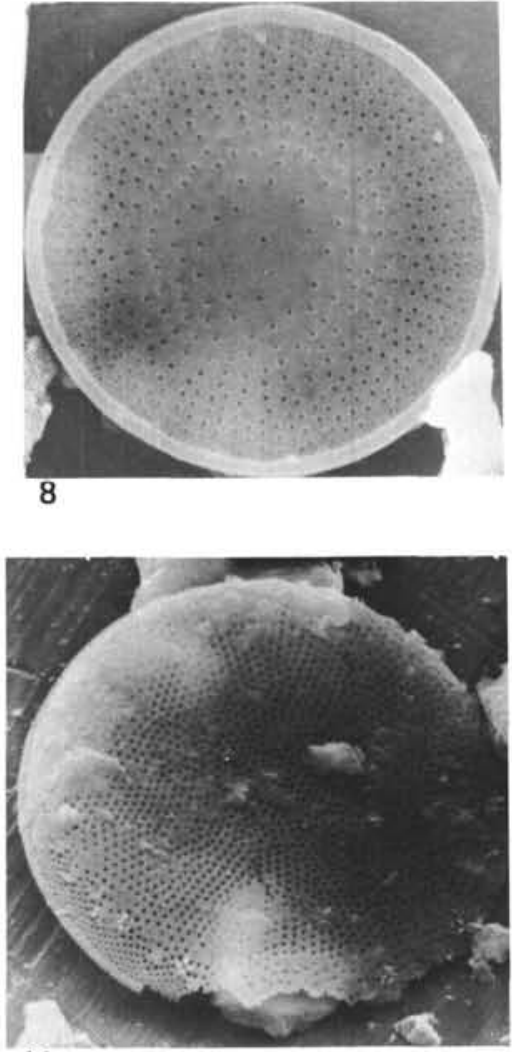

11
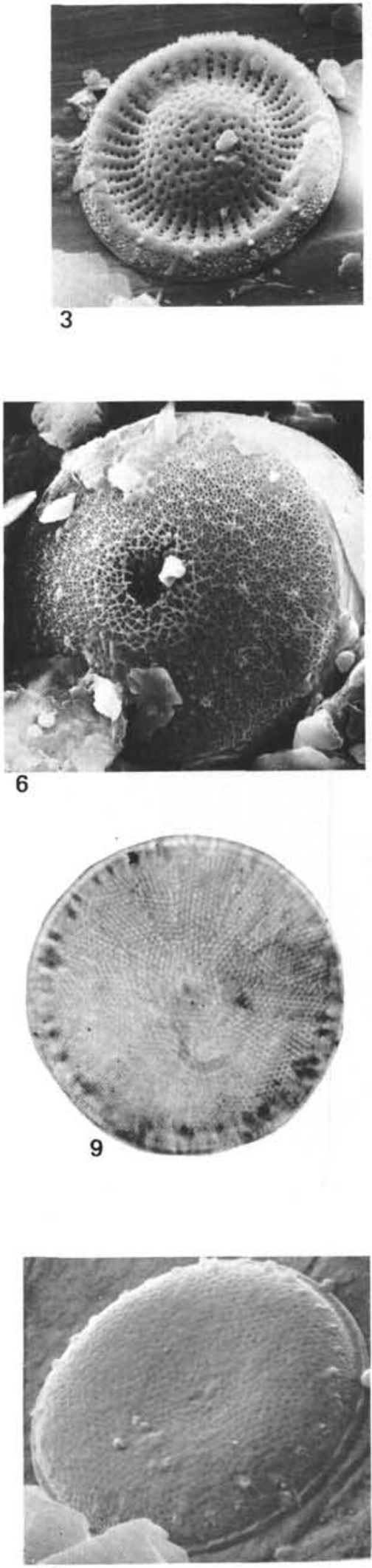
PLATE 22

"S. Vavilov," Core 1857.

Figure $1 \quad$ Stephanodiscus astraea (Ehr.) Grun.

Figure 2 Stephanodiscus astraea var. intermedia Fricke.

Figures 3-6 Thalassiosira aff, oestrupii (Ostf.) Pr.-Lavr.

Figure $7 \quad$ Asteromphalus robustus Castr.

Figure $8 \quad$ Cyclotella caspia Grun.

Figure 9 Hyalodiscus scoticus (Ktz.) Grun.

Figure 10 Bacteriastrum hyalinum Lauder.

Figure $11 \quad$ Thalassionema nitzschioides Grun.

Figure 12 Rhizosolenia calcar-avis Schultze.

Figure $13 \quad$ Rhizosolenia alata Bright.

Figure $14 \quad$ 2Rhizosolenia sp.

Figure $15 \quad$ Rhizosolenia setigera Bright.

PLATE 23

"S. Vavilov," Core 1857

Figures 1,2 Chaetoceros peruvianus Bright.

Figure 3 Chaetoceros sp. (spora)

Figure $4 \quad$ Cocconeis scutellum Ehr.

Figure $5 \quad$ Rhopalodia gibberula (Ehr.) O. Mull.

Figure $6 \quad$ Paralia sulcata (Ehr.) Ktz.

Figure 7 Nitzschia sp.

Figures 8, 10 Distephanus octonarius var. polyactis (Jorg.)

Gleser.-Silicoflagellatae.

Figure 9 Distephanus speculum (Ehr.) Hack.-Silicoflagellatae.

(see p. 950) 
PLATE 22
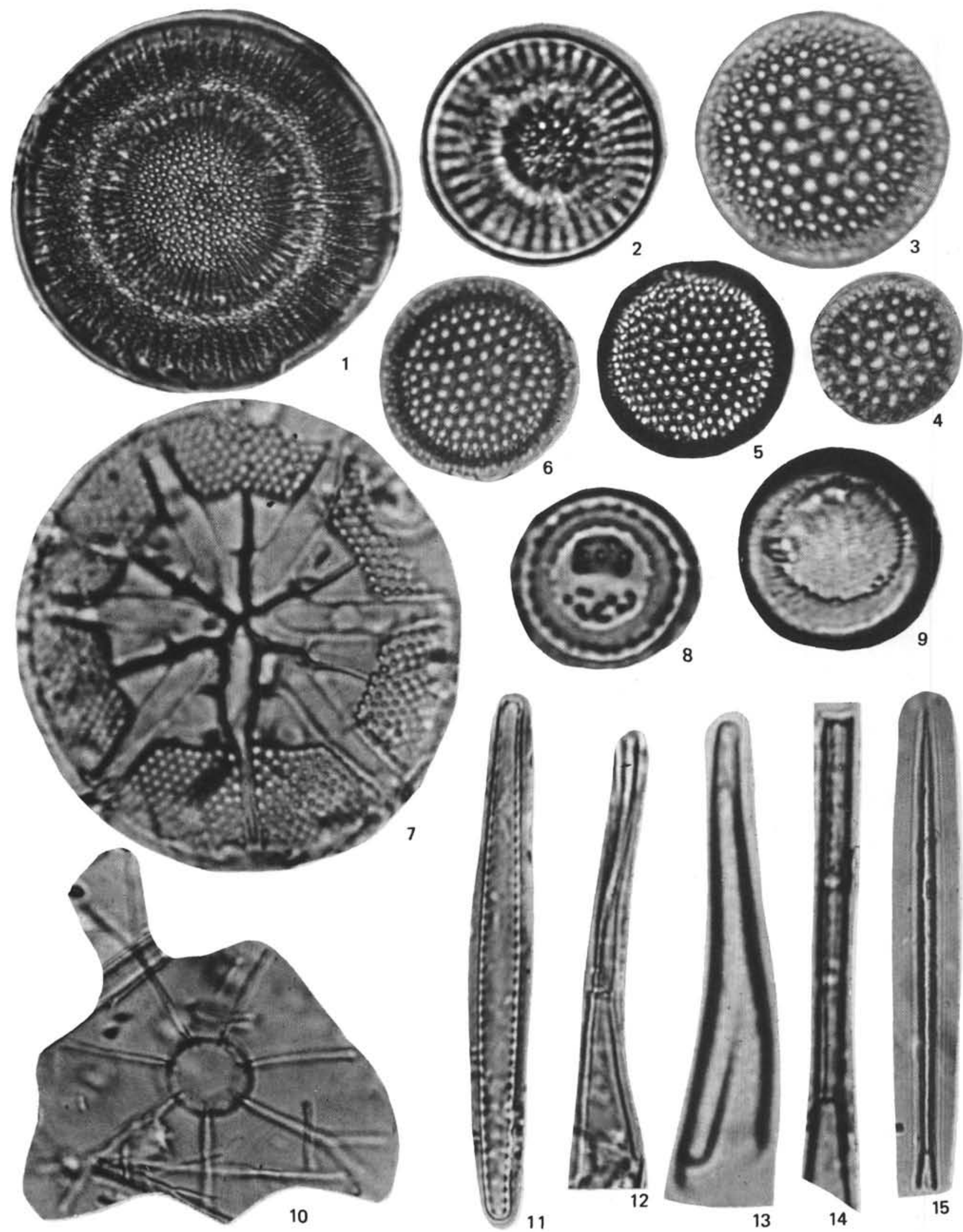
A. P. JOUSÉ, V. V. MUKHINA

PLATE 23
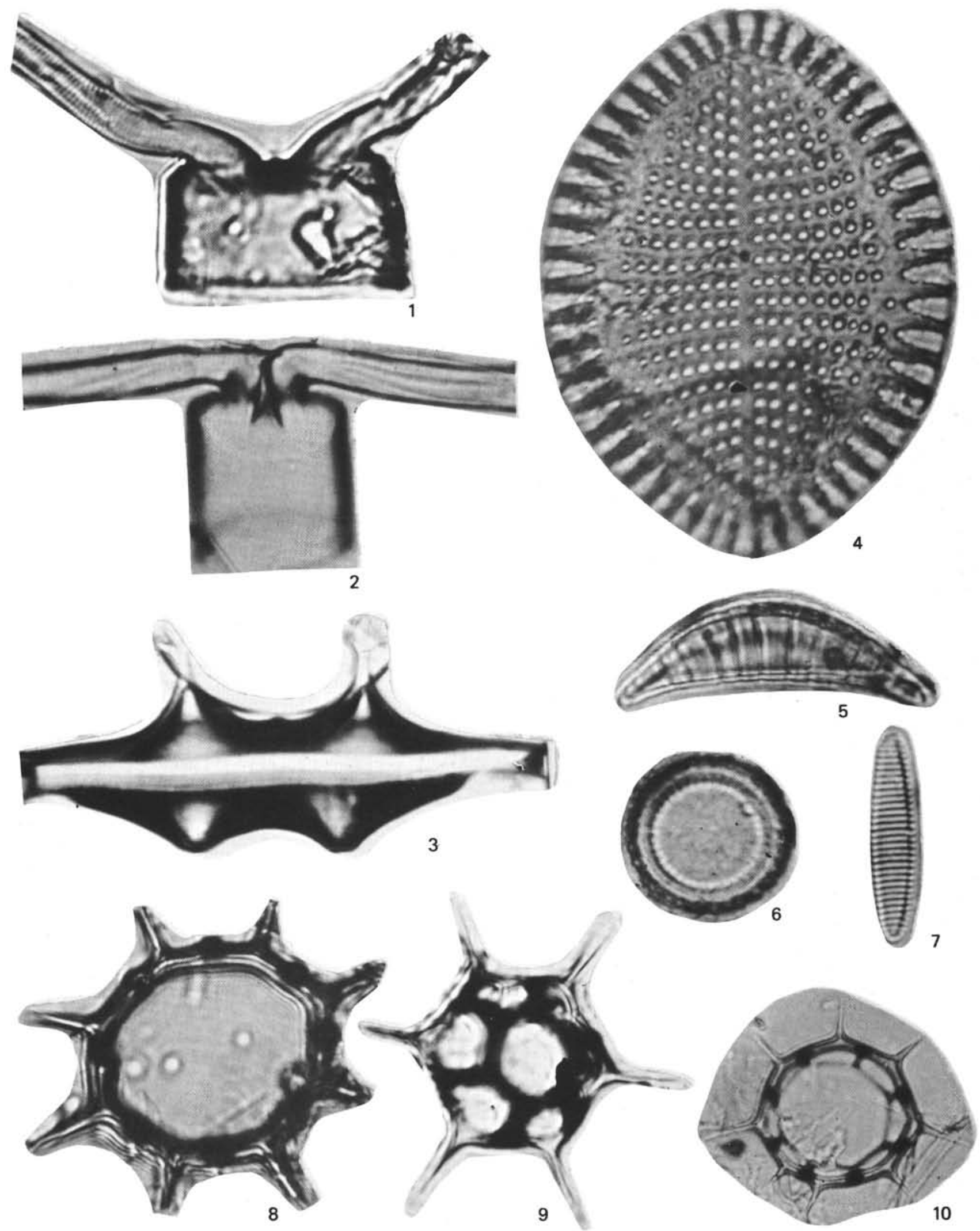